\title{
A MITOKONDRIÁLIS CITOKRÓM C POSZTTRANSZLÁCIÓS ÉRÉSE
}

\author{
Doktori értekezés
}

\section{Tenger Katalin}

Témavezető: Dr. Zimányi László

Konzulens: Dr. Rákhely Gábor

Biológia Doktori Iskola

Magyar Tudományos Akadémia

Szegedi Biológiai Kutatóközpont, Biofizikai Intézet

Szeged 2010 


\section{Tartalomjegyzék}

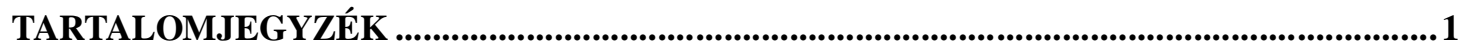

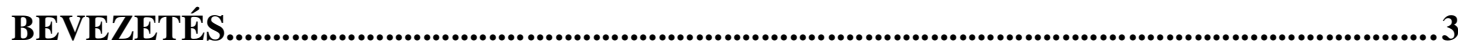

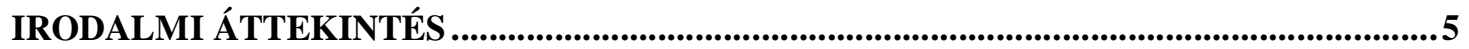

ELEKTRONTRANSZFER AZ ENERGIA-ÁTALAKÍTÓ BIOLÓGIAI RENDSZEREKBEN ….......................... 5

A $C$ TÍPUSÚ CITOKRÓMOK SZEREPE, ELŐFORDULÁSUK A BIOLÓGIAI RENDSZEREKBEN ÉS

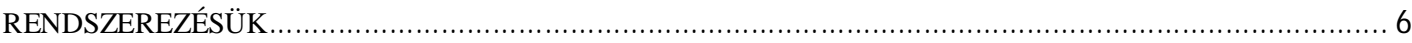

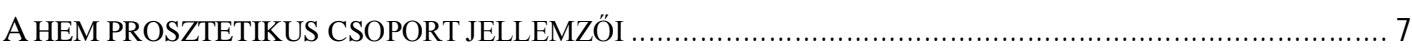

A $C$ TÍPUSÚ CITOKRÓMOK JELLEMZÖI ÉS A HOLOCITOKRÓM $C$ KIALAKULÁSA …………………….... 8

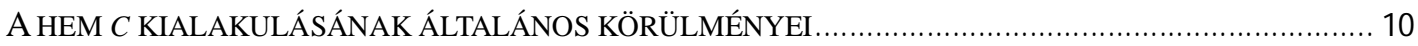

IN VIVO ÉRÉSI ELÖKÉSZÜLETEK ÉS A CITOKRÓM C ÉRÉSÉT VÉGZÖ RENDSZEREK ISMERTETÉSE..... 11

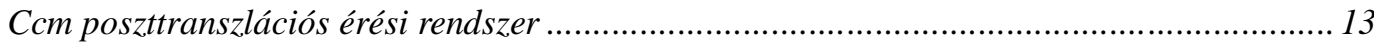

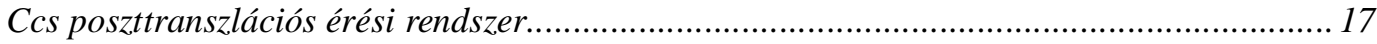

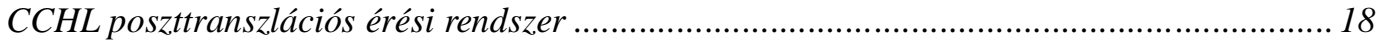

Más poszttranszlációs modifikációs rendszerek ………....................................................... 19

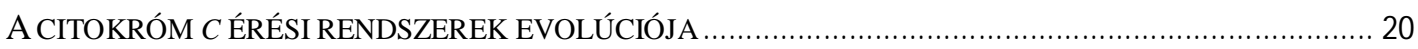



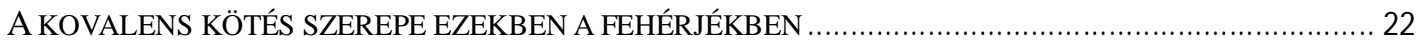

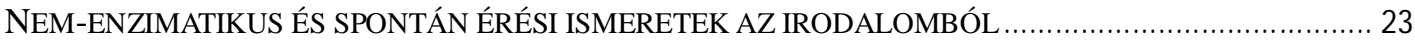

A MITOKONDRIÁLIS $C$ ÉS $C_{1}$ CITOKRÓMOKAT ÉRLELÖ CCHL ENZIM(EK) ………........................... 24

A CCHL azonosítása és poszttranszlációs mitokondriális importja ........................................24

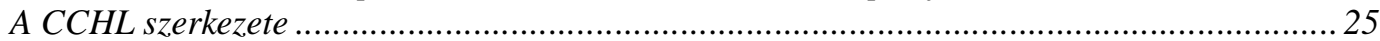

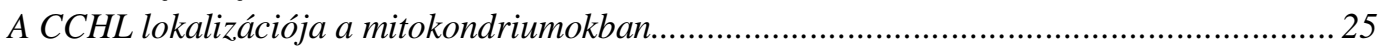

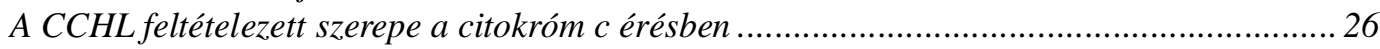

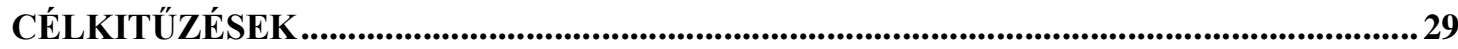

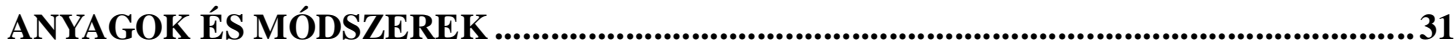

CITOKRÓM C ÉS CCHL FEHÉRJÉKET TÚLTERMELŐ PLAZMIDKONSTRUKCIÓK ÉS

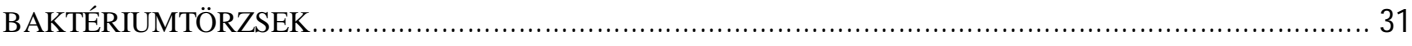

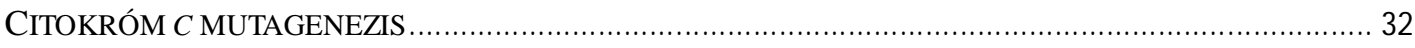

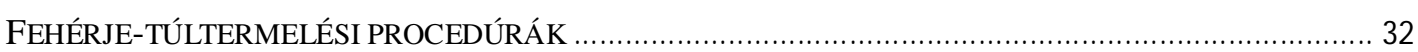

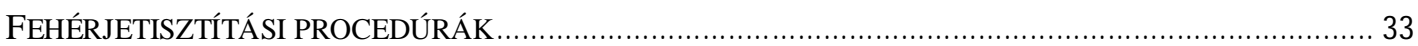

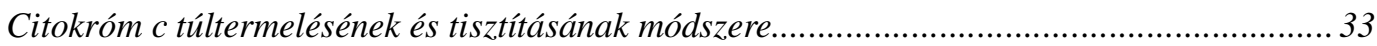

CCHL túltermelésének és tisztításának módszere ..................................................................... 33

FEHÉRJE TISZTASÁGVIZSGÁLATI ÉS ANALITIKAI MÓDSZEREK.................................................... 34

ABSZORPCIÓS ÉS CIRKULÁRIS DIKROIZMUS (CD) SPEKTROSZKÓPIAI MÉRÉSEK ............................ 34

HEM PEROXIDÁZ-AKTIVITÁSI MÉRÉSEK GÉLBEN .................................................................... 34

A PEPTIDFÚZIÓS FEHÉRJÉK AZONOSÍTÁSA IMMUNODETEKCIÓVAL …............................................. 35

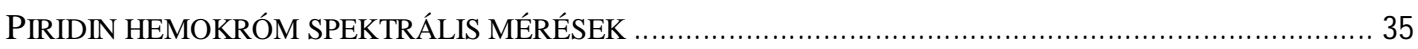

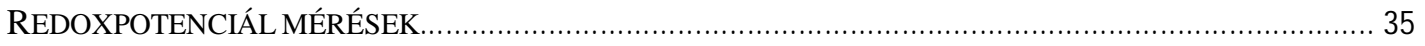




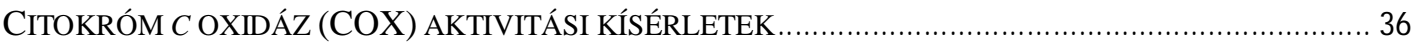

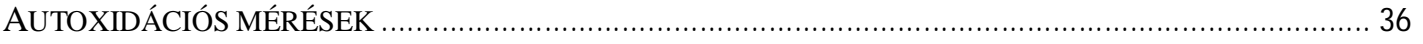

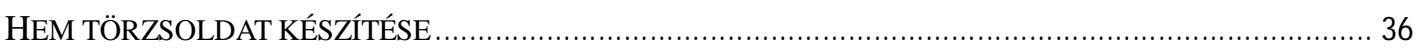

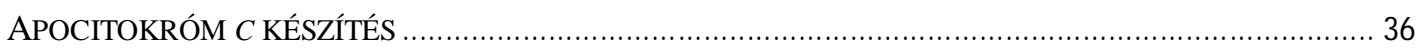

A CCHL ÉS AZ APOCITOKRÓM C OLDATOK KONCENTRÁCIÓJÁNAK MEGHATÁROZÁSA ................... 37

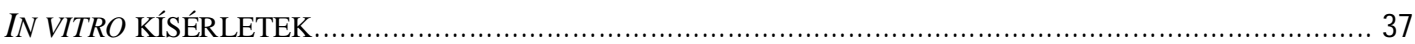

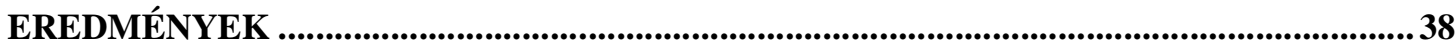

MUTÁNS C TÍPUSÚ CITOKRÓMOK TERMELTETÉSE HETEROLÓG EXPRESSZIÓS RENDSZERBEN........ 38

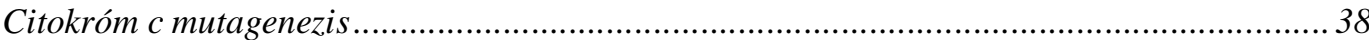

Heterológ citokróm c expresszió és fehérjeizoláció ................................................... 38

ELEKTRONTRANSZFER KÍSÉRLETEK CITOKRÓM C FEHÉRJÉBEN ÉS AZOK ÉRTELMEZÉSE ............... 40

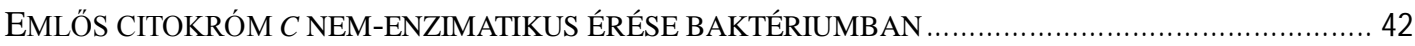

A citokróm c nem-enzimatikus érésének bizonyítékai: a fehérje detektálása ......................... 42

A citokróm c nem-enzimatikus érésének bizonyítékai: a hem kimutatása a fehérjében ............ 43 A citokróm c nem-enzimatikus érésének bizonyítékai: kontroll kísérlet Ccm mutáns törzsben. 43 A citokróm c nem-enzimatikus érésének bizonyítékai: az apocitokróm c expressziójának kinetikája .................................................................................................. 44

A citokróm c nem-enzimatikus érésének bizonyítékai: az apocitokróm c sorsa az E. coli citoplazmájában ....................................................................................... 44

A citokróm c nem-enzimatikus érésének bizonyítékai: spektroszkópiai vizsgálatok .................46 A nem-enzimatikusan érö citokróm c funkcionalitásának vizsgálata: középponti redoxpotenciál

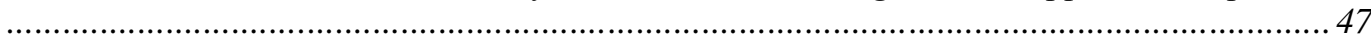
A nem-enzimatikusan érő citokróm c funkcionalitásának vizsgálata: elektrontranszfer aktivitásának paraméterei ....................................................................... 47 A nem-enzimatikusan érö citokróm c funkcionalitásának vizsgálata: autoxidációs kísérlet..... 48 A nem-enzimatikusan érö citokróm c hemjének enyhén megváltozott molekuláris környezete és/ vagy geometriája van.

A CCHL TÚLTERMELÉSÉNEK FELTÉTELEI, AZ ENZIM TISZTÍTÁSA, SZERKEZETI ÉS SPEKTRÁLIS

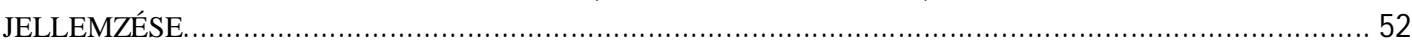

A CCHL túltermelése és tisztítása............................................................................. 52

A tiszta CCHL vizsgálata ...................................................................................... 52

A CCHL szerkezeti jellemzése .................................................................................. 54

A CCHL UVCD spektruma és várható másodlagos szerkezeti összetétele .............................. 56

A CCHL hem kötésének vizsgálata .................................................................. 57

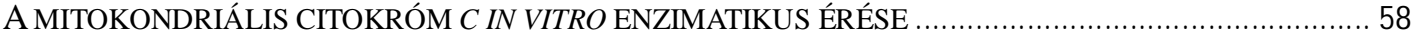

AZ EREDMÉNYEK MEGVITATÁSA .............................................................................61

KÖSZÖNETNYILVÁNÍTÁS .........................................................................................69

IRODALOMJEGYZÉK ..................................................................................................70

ÖSSZEFOGLALÁS .............................................................................................................80

SUMMARY 


\section{Bevezetés}

A c típusú citokrómok esszenciális hemtartalmú fehérjéi majdnem minden élőlénynek. Szerkezeti és funkcionális sokszínüségükben a közös vonást a kovalensen kapcsolt prosztetikus csoportjuk jelenti, amely színt és jellegzetes abszorpciós spektrumot kölcsönöz a fehérjéknek. A hem kovalens kötésére a $c$ típusú citokrómok döntő többsége egy Cys-Xxx-Xxx-Cys-His hemkötő motívumot tartalmaz. A poszttranszlációs lépést, amely a hem kovalens kapcsolását jelenti a hemkötő motívumhoz, a $c$ típusú citokrómok érésének nevezzük. A $c$ típusú citokrómoknak többféle típusú és különféle bonyolultságú érlelő rendszere ismert. A kovalensen kötött hem, a citokróm $c$ fehérjék sokszínüsége és a $c$ típusú citokrómok érleléséhez kialakult többféle rendszer megléte számos, még megválaszolatlan kérdést vetnek fel szerkezeti, müködésbeli és evolúciós szempontból.

A sokféle szerkezettel és funkcióval bíró $c$ típusú citokrómok közül az elektrontovábbító szerepet betöltő mitokondriális szolubilis $c$ típusú citokrómok különösen alkalmasak különféle kísérletek elvégzésére. Ezek a fehérjék a mitokondriumok intermembrán terében helyezkednek el, a légzési lánc komponensei, és két membránkötött partnerük között $\mathrm{H}^{+}$transzport nélkül szállítanak elektronokat.

A kísérleteinkben felhasznált mitokondriális ló citokróm $c$ alkalmas lehet arra, hogy heterológ in vivo és in vitro citokróm $c$ érési kísérletekkel a helyes érés biokémiai feltételeit tisztázni lehessen. A mitokondriális $c$ típusú citokróm érési vizsgálatokon túl alkalmas elektrontranszfer kísérletek elvégzésére is. A $c$ típusú citokrómok nem fotoaktív redoxmolekulák abban az értelemben, hogy az elektronfelvételt és -leadást a hemcsoport elektronikus gerjesztése nélkül végzik. Gyors, jó időfelbontású elektrontranszfer vizsgálatokhoz célszerü kovalensen és aminosavakra nézve szelektíven jelölni azokat fénnyel gerjeszthető, fotoaktív (azaz gerjesztett állapotban redox aktív) molekulákkal, festékekkel. A szelektív jelöléshez felületi, funkció szempontjából semleges aminosavakat kell mutagenezissel jelölhetőekre cserélni. A külsőleg kovalensen hozzáadott festék előnye az, hogy a fehérje bármilyen kívánt pozícióban jelölhető, miáltal a donor és az akceptor (azaz a festék és a hem) távolsága, az elektrontranszfer iránya szinte tetszőlegesen változtatható. Az ily módon jelölt fehérjéken végzett elektrontranszfer kísérletek választ adhatnak a fehérjekomplexeken, ill. fehérjéken belüli elektrontranszfer mechanizmusának és természetének a kérdésére.

A mitokondriális citokróm $c$ és mutánsainak előállításához gondoskodni kell nemcsak a fehérje expressziójáról, hanem annak éréséről is, azaz a hem kovalens kötéséről 
és a fehérje megfelelő feltekeredéséről. Ehhez valamely érlelő rendszer megfelelő fehérjéjét is ki kell fejezni a gazdasejtben. A citokróm mutánsok eloállításának igénye természetesen vezetett el dolgozatom fő témájához, a citokróm $c$ érésének és az érlelő fehérje, a citokróm $c$ hem liáz (CCHL) müködésének vizsgálatához. 


\section{Irodalmi áttekintés}

\section{Elektrontranszfer az energia-átalakító biológiai rendszerekben}

A biológiai rendszerek energia-átalakító membránjaiban igen sok, prosztetikus csoportokat és fém központokat is tartalmazó redox fehérje található. Az általuk kialakított redoxláncban az elektronoknak előrehaladásuk során nagy sebességgel és irreverzíbilisen kell viszonylag nagy távolságokat megtenniük. Ez a távolság intramolekulárisan jellemzően 5 - 15 Á, intermolekulárisan pedig ennél nagyobb is lehet. Az elektrondonor és -akceptor kofaktorok a fehérjéken, ill. fehérje-komplexeken belül sokszor rögzített pozíciókban helyezkednek el. Az elektronok kis távolságra, alagúteffektussal akár vákuumban is képesek tovahaladni, ilyenkor a donor és akceptor közötti távolsággal az elektrontranszfer sebességi állandója a Marcus elmélet értelmében 0,8 Á-ként tizedére csökken. Biológiai közegben a távolságot kitöltő fehérjemátrixnak egyértelmű elektrontranszfert elősegítő szerepe van, ugyanis a fenti veszteséget általánosan több mint kétszeresével csökkenti, csupán 1,7 Áként csökken tizedére a sebesség (Berg 2007). A fehérjemátrix szerepe az elektrontranszfer elősegítésében különböző bonyolultságú modellekkel értelmezhető. A modellek használhatóságát illetően a vélemények megoszlanak. Az első modell eredeti megfogalmazása szerint a fehérje homogén, izotróp közegnek tekinthető, és az elektrontranszfer sebessége adott donor és akceptor között az öket elválasztó térbeli távolságuktól függ (Moser 1992). Ez a modell az idők során finomodott abban az értelemben, hogy a fehérjemátrixot nem teljesen homogén, hanem sürübb és ritkább tartományokból álló, de továbbra is folytonos közegnek tekinti (packing density modell, Page 1999). A fehérjék atomi szerkezetét figyelembe vevő bonyolultabb (ún. útvonal v. pathway) modell az elektrondonort és -akceptort elválasztó térrészt kovalens kötésekből, hidrogén hidakból és rövid térbeli ugrásokból (van der Waals kontaktusokból) álló útvonalakra bontja. Ezután megkeresi ezek közül az optimális útvonalat, azaz azt, mely a legkevesebb és leghatékonyabb láncszemből áll (Winkler 1997).

A mitokondriumok belső membránjában funkcionálisan lánccá füzött redox fehérjéken keresztül hosszútávú elektrontranszfer folyamatok zajlanak az elektrondonor szubsztrátoktól (NADH, szukcinát (borostyánkősav)) a végső elektronakceptor (molekuláris oxigén) felé (1. ábra). Ezen légzési elektrontranszport közben az egyre pozitívabb középponti redoxpotenciál felé haladó elektronok szabadenergiája nem disszipálódik, hanem a membránon keresztül folyó protontranszport (protonpumpálás) révén átmenetileg transzmembrán proton elektrokémiai energiává alakul át. A Mitchell-féle kemiozmotikus 
elmélet értelmében ez a protongrádiens hasznosul az oxidatív foszforiláció utolsó lépéseként, az energia-átalakító membránban elhelyezkedő ATP szintetáz fehérjekomplexben az ATP szintézis során (Nicholls 2002, Alberts 2008). Lényegileg hasonló módon zajlik az energia-átalakítás és -felhasználás a baktériumok sejtmembránjában, azzal a különbséggel, hogy mind a szubsztrátok, mind a végső elektronakceptor szempontjából nagy változatosságot mutatnak, és ennek megfelelően a redoxláncban szereplő fehérjéknek is széles skáláját ismerjük.

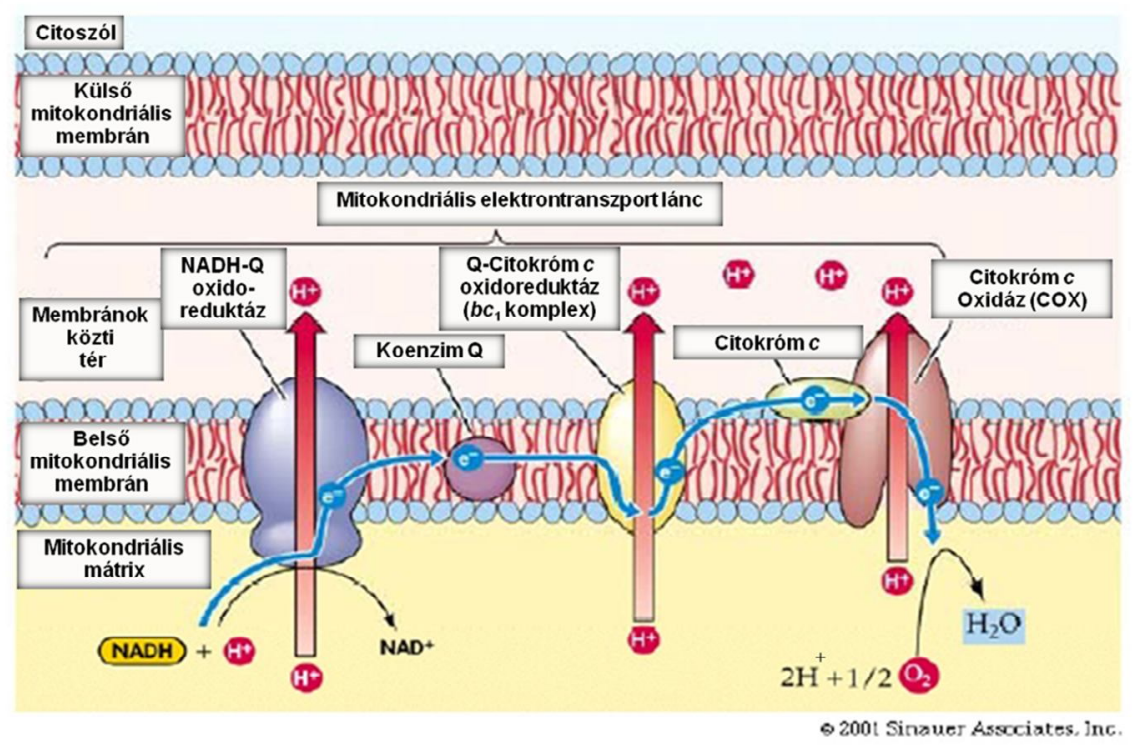

1. ábra. A mitokondriális légzési lánc és a $c$ típusú citokróm helye a láncban.

\section{A c típusú citokrómok szerepe, előfordulásuk a biológiai rendszerekben és rendszerezésük}

A c típusú citokrómok különböző fotoszintetikus és légzési elektrontranszfer folyamatokat látnak el a sejtek megfelelö energia-átalakító membránjaiban. Emellett a $c$ típusú citokrómok gázok megkötésében és bizonyos oxidációs folyamatokban is részt vesznek, illetve ismert, hogy bizonyos eukariótákban kiszabadulva a mitokondriumból olyan jeltovábbító eseményeknek az elindítói, amelyek a programozott sejthalálhoz (apoptózis) vezetnek (Ott 2007).

A mitokondriális $c$ típusú citokrómokra jellemző, hogy egy hemet tartalmaznak és az aerob légzési elektrontranszport láncban helyezkednek el. A prokarióták világában több száz különféle szerkezetü és funkciójú citokróm $c$ létezik és elektrontranszfer szerepükön túl enzimek katalitikus központjaként is szerepelhetnek. A prokarióták esetében egy - egy polipeptidláncra akár 10 hem is juthat. A prokarióták $c$ típusú citokrómjai különféle körülmények között indukálódó elektrontranszfer-láncok résztvevői. A légzési és 
fotoszintetikus elektrontranszfer-láncokon túl részt vesznek olyan láncokban is, amelyek terminális akceptorai lehetnek nitrátok, dimetil szulfoxid, különböző fémek és sok más anyag (Nicholls 2002). Többek között ez a respirációs sokféleség, amelyben a $c$ típusú citokrómok is részt vállalnak az, ami a prokariótákat oly sikeres alkalmazkodókká tette, képessé arra, hogy szinte minden életteret be tudjanak népesíteni.

A dolgozatom témájául szolgáló mitokondriális $c$ típusú citokróm az intermembrán tér szolubilis fehérjéje, amely elektrosztatikus kölcsönhatásokkal a belső membránhoz, főleg a negatív töltésü kardiolipin P-csoportjaihoz tapadva mozog laterális irányban, elektronhordozó szerepet látva el a redoxláncban (1. ábra) (Zhang 2002).

A c típusú citokrómok osztályozása szerint (Ambler 1991) a mitokondriális citokrómok a Class I csoportba tartoznak. Ebbe a csoportba tartoznak a szolubilis bakteriális citokróm $c$-k is. A csoport képviselőire jellemző, hogy redukált Fe-ionjuk alacsony spinü, az N-terminális végük közelében tartalmazzák a hemkötő $(\mathrm{CXXCH})$ motívumot és, hogy a szekvenciában a motívumtól a C-terminális irányba haladva helyezkedik el a hem vasának hatodik koordinátora, amely egy metionin aminosav. Tartalmaznak négy darab központi $\alpha$ hélixet, amelyek egy, az oldat felé nyitott, „kosarat” képeznek a hem számára, lehetővé téve ezáltal, hogy a hem egyik éle kilógjon az oldatba.

A Class II csoportba tartozó citokrómok lehetnek alacsony vagy magas spinűek, a hemkötő motívum a lánc C-terminális vége közelébe esik, a vas hatodik liganduma egy, az N-terminális közelében található metionin.

A harmadik, Class III, csoportba tartoznak az alacsony redoxpotenciálú (-400 - 0 $\mathrm{mV}$ ) többhemes citokrómok. Hemjeik kettős hisztidinnel koordináltak, a fehérjék pedig szerkezeti és funkcionális sokféleséget mutatnak.

A negyedik csoportba, Class IV, eredetileg azokat a komplex $c$ típusú citokrómokat sorolták, amelyek a hemen kívül egyéb prosztetikus csoporto(ka)t is tartalmaznak. Moore és Pettigrew (1990) pontosítása alapján ezek a citokrómok tetrahem fehérjék, amelyek mind kettős hisztidin, mind metionin- és hisztidin-koordinált hemmel rendelkeznek, és szerkezetileg egy homogén fehérjecsaládot alkotnak.

\section{A hem prosztetikus csoport jellemzői}

A hem $b$ (más nevén: protoporfirin IX vagy protohem IX) heterociklusos gyürüjének (porfirin gyürü) középpontjában elhelyezkedő vasat négy nitrogén koordinálja. A hem

gyürüjéhez annak szerkezeti és fizikai-kémiai paramétereit meghatározó fontos oldalláncok kapcsolódnak, így például a hem $b$ esetében két propionát és két viniloldallánc. A tetrapirrol 
gyürü szubsztituensei más - más hem típusokat eredményeznek; ilyen módosulás például a hem $c$ is, amely vinilcsoportjain keresztül kovalens tioéter kötéssel kapcsolódik a $c$ típusú citokrómok polipeptidláncához (2. ábra, A).

A hem szintéziséért a tetrapirrol bioszintetikus útvonal egyik ága felelős. Ennek utolsó lépése a mitokondriális belső membrán mátrix oldalán zajlik, amely során a redukált vasat $\left(\mathrm{Fe}^{2+}\right)$ a ferrokelatáz enzim építi be a molekulába. Ezt követően az amfipatikus hemnek át kell jutnia a membránon a felhasználása helyszínére, de nem ismert sem a transzportere, sem az esetleges segédfaktorok, amelyeknek létezniük kell a hem hatékony transzportja érdekében. A hem transzportjának mechanizmusára bizonyos ismeretek alapján létezik néhány hipotézis, de kísérleti bizonyítékok még egyiket sem erősítették meg (Hamel 2008). Az sem tisztázott, hogy a hem milyen oxidációs állapotban teszi meg az utat a belső membránon keresztül (Hamel 2008, Kranz 2009).

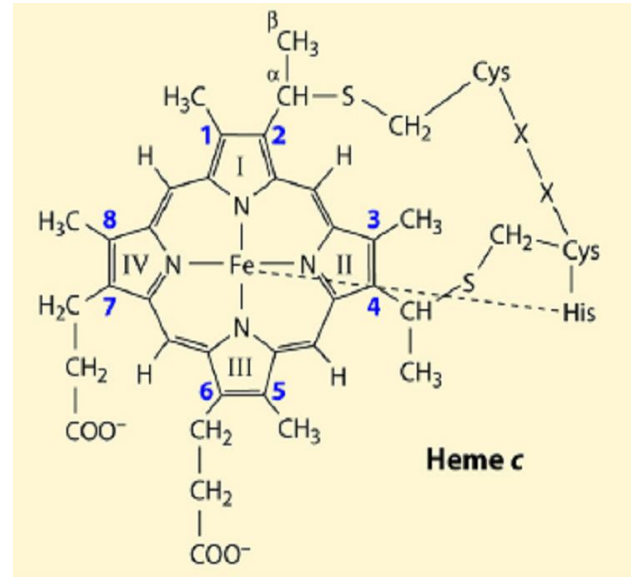

A

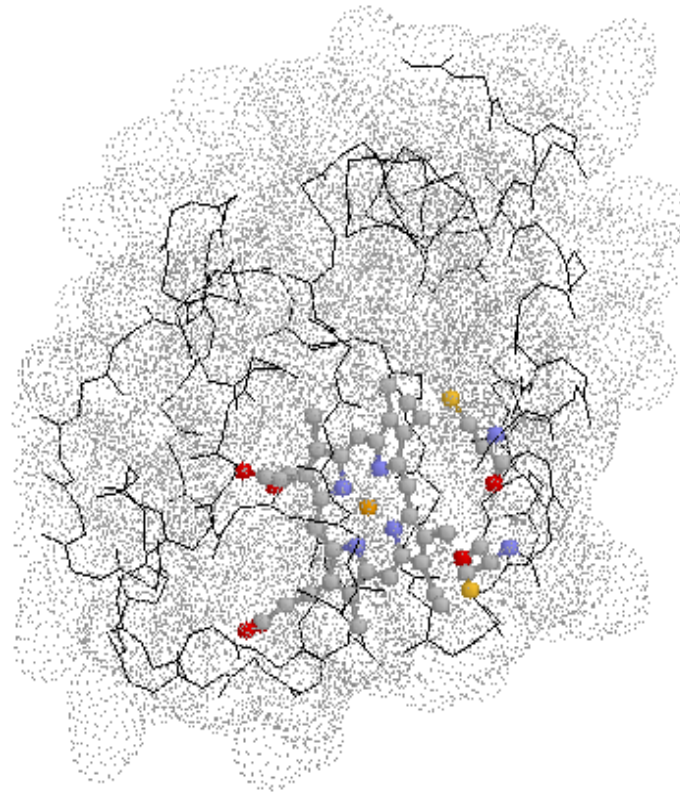

B

2. ábra. A: A c típusú hem szerkezete. Ábrázolás a Fischer számozás szerint (Kranz 2009). B: Ló szívizom citokróm $c$ háromdimenziós szerkezete, PDB kód: 1HRC (www.proteinexplorer.org).

\section{A $c$ típusú citokrómok jellemzői és a holocitokróm $c$ kialakulása}

A c típusú citokrómok elektrontranszfer feladatukat a vas vegyérték-elektron változásai, azaz a hemcsoport redukciója, ill. oxidációja révén valósítják meg. A hem oxidációs állapotának megfelelően változik az abszorpciós spektruma is. A $c$ típusú citokrómok abszorpciós spektrumában van egy domináns, ún. Soret csúcs 400 nm közelében és egy, az előbbinél jelentősen kisebb extinkciójú, ún. Q sáv 500 és 600 nm 
között, amelynek alakja a prosztetikus csoport oxidációs állapotától függően változik; redukált állapotban két keskenyebb ún. $\alpha$ és $\beta$ csúcsra bomlik.

A $c$ típusú citokrómokban a hem jellemzően egy Cys-Xxx-Xxx-Cys-His hemkötő motívum két cisztein oldalláncán (2. ábra, A és B), de ritka esetben egy ciszteinen keresztül kötődik a polipeptidlánchoz. A hem vinil-oldalláncai tioéter kötés kialakításával kapcsolódnak a cisztein-oldalláncok szulfhidril-csoportjához. A tioéter kötések megléte, illetve számuk (1 vagy 2) befolyásolják a $c$ típusú citokrómok abszorpciós spektrumát, így a redukált fehérje spektrumának $\alpha$ és $\beta$ csúcsai a különböző szubsztituensekkel rendelkező hemeknek köszönhetően más és más maximumot mutatnak.

A nem-kötött, egyszeresen kötött, illetve kétszeresen kötött hemek redukált piridin hemokróm spektrumai jellegzetes $556 \mathrm{~nm}, 552 / 553 \mathrm{~nm}$, illetve 549/550 nm maximumokat mutatnak. A redukált, piridin-koordinált hemcsoportok spektrumai a különböző hem típusokra jellemzőek, ugyanis a méréshez szükséges denaturáló körülményeknek köszönhetően a fehérje-környezettől független spektrumot adnak. A piridin-koordinált hemokróm spektrum egyrészt információt szolgáltat arról, hogy az adott $c$ típusú citokrómban hányszoros a hem kötése (azaz a hem módosulásának természetéről), másrészt arról, hogy in vivo, de heterológ expresszióval vagy in vitro körülmények között érő citokróm $c$ esetében az érés megfelelően történt-e (Allen 2005a, 2009).

A polipeptidlánc hemkötő motívumának két ciszteinje közötti aminosavak száma változó lehet, de a leggyakoribb a fent jelölt változat, ahol az Xxx jelölés bármilyen aminosavat jelölhet, kivéve ciszteint. A $c$ típusú citokrómokban a hem vasa hatszorosan koordinált, amelyekből négy kötés a hem tetrapirrol gyürüjének nitrogénjeivel jön létre. A motívum hisztidin-oldallánca az ötödik, proximális, axiális liganduma a vasnak, míg hatodik liganduma a polipeptid lánc egy disztális pontján elhelyezkedő metionin vagy hisztidin aminosav (Hamel 2008).

A hem elhelyezkedése a polipeptidlánchoz képest sztereospecifikusan konzervált a citokróm $c$ fehérjék családján belül. A tetrapirrol gyürü 2-vinilcsoportja a hemkötő motívum N-terminális irányába eső ciszteinjéhez, a 4-vinilcsoportja pedig a C-terminális irányába eső ciszteinhez kapcsolódik (2. ábra, A) (Sanders 2010).

A hem kovalens kötését jelentő poszttranszlációs módosulást a $c$ típusú citokrómok érésének, maturációjának nevezzük, amely tulajdonképpen a hem $c$, azaz a holocitokróm $c$ szintézisét jelenti. Az apocitokróm $c$ és a hem $b$ kovalens összekapcsolása enzimatikus folyamat (Dumont 1987). Bizonyos biológiai rendszerekben ezt a folyamatot egyetlen enzim is képes katalizálni, de sok esetben bonyolult enzimkomplexek közötti összjáték 
révén valósul meg ez a látszólag egyszerü reakció.

A holocitokróm $c$ érését az teszi még érdekesebbé és egyben komplikáltabbá is, hogy mind a mitokondriális, mind a bakteriális többhemes $c$ típusú citokrómok döntő többségében a polipeptidlánc a hemkötés után tekeredik fel és éri el végső háromdimenziós szerkezetét. Történik ez oly módon, hogy a hem kötése nukleációs helyet képez a fehérje foldingjában. Ez ellentétben áll sok más hemtartalmú fehérje, mint pl. a hemet kovalensen nem kötő $b$ típusú citokrómok és a globinok feltekeredésével. Ismert, hogy ezen $c$ típusú citokrómok polipeptidlánca kötött hem hiányában lebomlik, míg az apoglobinok és $b$ típusú apocitokrómok megfelelően feltekerednek hem hiányában is (Barker 1999). Így ez utóbbiak jól tisztíthatóak és mutánsaikkal a $c$ típusú citokrómok érése könnyebben rekonstituálható, vizsgálható. Megjegyzendő azonban, hogy kivételek is vannak: például a Pseudomonas aeruginosa citokróm $c_{551}$ (Borgia 2008) vagy a Hydrogenobacter thermophilus $c_{552}$ citokrómja hem vagy hem kovalens kötésének hiányában is feltekeredik stabil konformációs állapotába (Tomlinson 2000a).

\section{A hem $c$ kialakulásának általános körülményei}

A kovalens kötés kialakulásához a hemkötő CXXCH motívum ciszteinoldalláncainak redukált állapotban kell lenniük. A kötés a Markovnyikov-szabály értelmében a hem vinilcsoportjainak $\alpha$-C-atomjai és a cisztein-oldalláncok $S$-atomjai között alakul ki. A kötésképződés során a redukált hem vinilcsoportjainak elektronsürüsége nagyobb, így a hem kovalens kötése a vinilcsoportok szemszögéböl nukleofil támadás eredménye. A reakció során tehát a nukleofil támadáshoz redukált hem preferált az oxidálttal szemben, mert ez esetben kémiailag aktívabbak a vinilcsoportok (3. ábra) (Kranz 2009). Esetleges oxidált hem és tiolcsoport találkozása kétféleképpen is beleszólhat a $c$ típusú hem kialakulásába, egyrészt a vasnak a tiolcsoport általi koordinációja megakadályozhatja a kötés kialakulását, másrészt a tiolcsoport oxidációja után visszamaradt gyök kezdeményezheti egy alternatív hemmódosulat kialakulását (Barker 1993).

$\mathrm{Az}$ érés redox kémiájával kapcsolatos ismeretek néhány úttörő holocitokróm $c$ rekonstitúciós munkából származnak. In organello citokróm $c$ import kísérletek bizonyították, hogy redukáló feltételek szükségesek az éréshez (Nicholson 1989, Tong 1998). A hem vasának oxidációs állapotáról egy hemtartalmú fehérjével végzett rekonstitúciós kísérlet szolgáltat információt (Barker 1993). Ezekből a kísérletekből azt tudjuk meg, hogy amikor a két partner összetalálkozik, a hem oxidációs állapota kritikus meghatározója a helyes tioéter kötés kialakulásának. Oxidált hem esetén alternatív 
tiolszármazék alakulhat ki. Ráadásul a hem oxidációs állapota esetenként attól is függhet, hogy a vinilcsoportnak milyen aminosavval kell kovalens kötést létesítenie. Aszkorbát peroxidáz enzimmel bizonyították, hogy a 2-vinilcsoport és a polipeptidlánc közötti kovalens kötés létrejöttéhez a vasnak különböző oxidációs állapotban kell lennie attól függően, hogy milyen aminosavhoz kapcsolódik. Ha például az enzim a megfelelö pozícióban egy cisztein mutáns volt, akkor a vasnak redukáltnak, ha ez az aminosav metionin volt, akkor oxidáltnak kellett lennie (Metcalfe 2007).

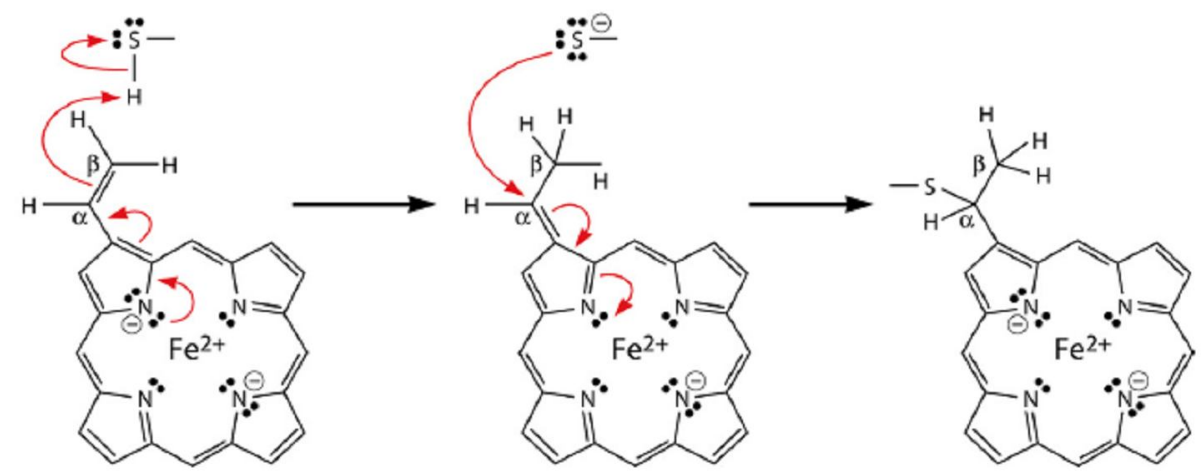

3. ábra. A $c$ típusú hem szintézise. Bemutatva a 2-vinilcsoport $\alpha$-C-atomján, amely a $\mathrm{CXXCH}$ hemkötő motívum N-terminális felé eső ciszteinjével reagál (Kranz 2009).

\section{In vivo érési előkészületek és a citokróm $c$ érését végző rendszerek ismertetése}

A c típusú citokrómok, a velük végzett nagyszámú szerkezetanalízis és elektrontranszfer kísérleteknek köszönhetően az egyik legjobban jellemzett és leginkább tanulmányozott fehérjecsoport, de érésük biokémiai feltételeiről és annak molekuláris mechanizmusáról keveset tudunk (Thöny-Meyer 1997, Allen 2003a).

A $c$ típusú citokrómok biogenezis rendszerei általánosan három nagy csoportba sorolhatók (Sys I, Sys II, Sys III) (Kranz 1998, Hamel 2008), de újabban ismertté vált néhány további, kifejezetten specializált érlelő rendszer is. A háromféle maturációs rendszernek közös funkcionális vonásai vannak, de óriási komplexitásbeli különbségeket mutatnak. Komplexitásuk mértéke nincs összefüggésben a szervezet evolúciós komplexitásával.

A leginkább prokariótákban és növényi mitokondriumokban előforduló Sys I a legbonyolultabb, legkevesebb 9 fehérjéből álló komplex. A Sys II, amely néhány prokarióta, de föképp a kloroplasztiszok $c$ típusú citokrómjainak az érlelő rendszere, legkevesebb 3 fehérjés komplex. A Sys III rendszert csupán egy fehérje alkotja, amiből például gombákban kétféle változat is elöfordulhat, míg magasabbrendü állatokban pedig már csak egy. A citokróm $c$ érlelő rendszerei akár egy szervezeten belül is különbözhetnek; pl. az 
Euglenozoa törzsbe tartozó fotoszintetikus algák esetében a mitokondriális $c$ típusú citokrómok érleléséért egy atipikus rendszer a felelős, míg kloroplasztiszaik citokrómjait a Sys II rendszer érleli. Jellemző tehát, hogy a növények energia-átalakító membránt tartalmazó sejtszervecskéinek érlelő rendszerei jelentős különbségeket mutatnak, amely jelenség a sejtszervecskék evolúciós eredetével függhet össze.

A $c$ típusú citokrómok apofehérjéi a transzláció után a membránon keresztül abba a sejtrészlegbe kerülnek, ahol érésük után a funkciójukat is ellátják. Ez a sejtkompartment minden esetben az energia-átalakító membránok pozitív, azaz $p$, oldala, amely a baktériumok esetében a citoplazmamembrán periplazmatikus tér felöli oldala, a plasztiszok tilakoid lumene és a mitokondriális intermembrán tér. A hem $b$ bioszintézise és transzportja, illetve az apocitokróm $c$ transzlokációja egymástól független és különböző mechanizmusok által valósul meg.

Az érés során a hem Fe-atomjának és az apocitokróm $c$ cisztein-oldalláncainak redukált állapotáról az érlelő rendszereknek kell gondoskodniuk. A Sys I és Sys II rendszerek esetében a ciszteinek redukciója jól ismert lépés, ezt a DsbD/CcdA membránfehérje és a CcmG, ill. CcsX tioredoxin-szerü fehérjék végzik (Sanders 2010). A III rendszer esetében létezik egy nemrég célkeresztbe került flavoprotein, amely a hemen kívül potenciálisan redukálhatja az apocitokrómot is (Bernard 2003, 2005). Az érlelő rendszer chaperonjai és katalizátor enzimei biztosítják azt is, hogy a hem sztereokémiailag mindig azonos orientációban legyen a polipeptidlánchoz kötve.

A különböző érlelő rendszerek - utalva itt a bonyolult Sys I és Sys II rendszerekre, amilyeneket a különböző prokariótáknál, a kloroplasztiszoknál és a növényi mitokondriumoknál ismerünk, - fehérje-összetétele változó, de közös bennük az, hogy a komponenseik funkcionálisan modulokba szerveződnek. A rendszereknek vannak a szubsztrátok (hem és apocitokróm $c$ ) előkészítéséért és „kézbesítéséért” felelős moduljaik és van egy katalízist végző moduljuk is. Az érési rendszerek moduláris felépítése valamennyi organizmusra jellemző, viszont komplexitásuk igen különböző lehet az egyes esetekben (4. ábra) (Sanders 2010). A Sys I és Sys II érési rendszerek elemei nagyrészt integráns membránfehérjék, de néhányuk a megfelelő sejtkompartmentben a membránhoz horgonyozva egy nagy szolubilis doménnel rendelkezik. A Sys III érlelő fehérjéje nagy valószínűséggel membránfelszínhez tapadó szolubilis fehérje (Enosawa 1986). 


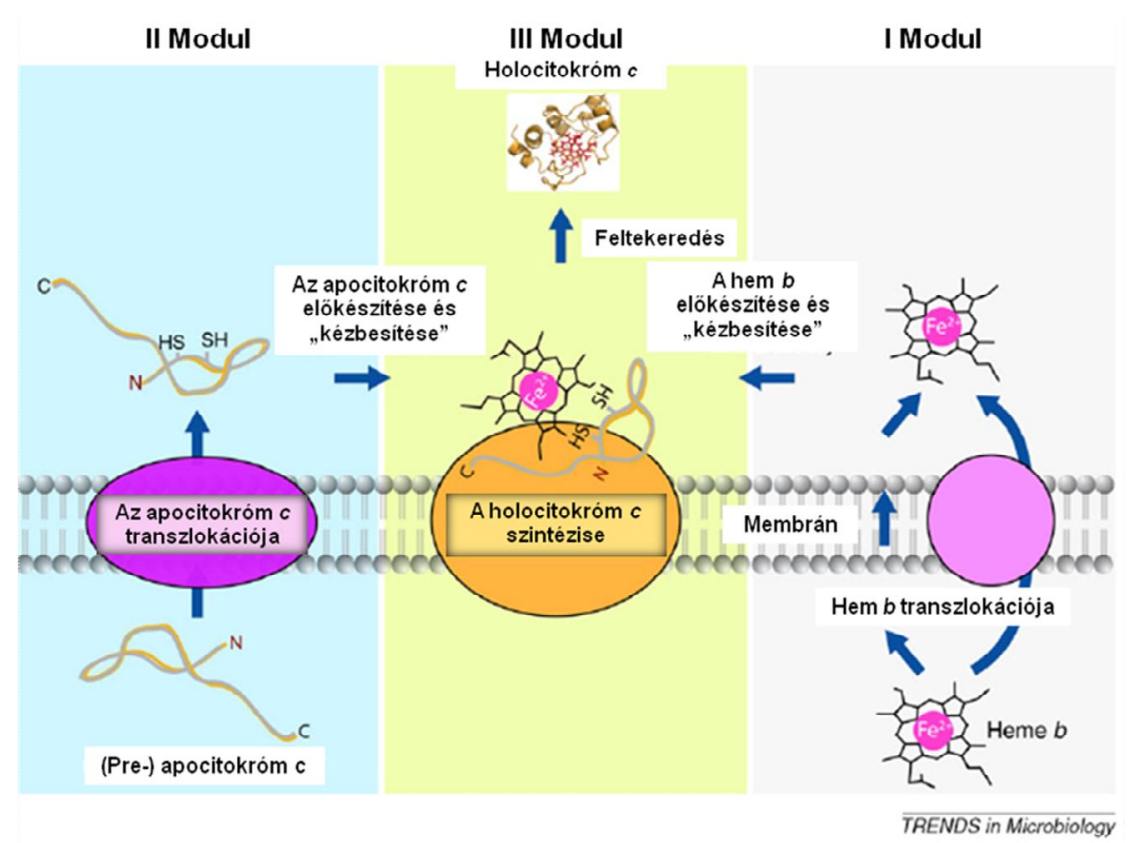

4. ábra. A citokróm $c$ maturációs rendszerek moduláris felépítésének modellje (Sanders 2010). I modul: a hem transzlokációjáért felelős. II modul: az apocitokróm $c$ elökészítéséért felelős. III modul: a kovalens kötés katalíziséért felelős.

Ccm poszttranszlációs érési rendszer

A Ccm (citokróm $c$ maturáció) rendszer, más megnevezéssel Sys I (5. ábra) Gramnegatív baktériumokban ( $\alpha$ - és $\gamma$-proteobaktériumok), Deinococcus fajokban, növényi mitokondriumban, bizonyos véglények mitokondriumában, vörös algákban és archaebaktérimokban fordul elő. A citokróm $c$ maturációt jelentő poszttranszlációs és posztexport módosítást a legtöbb Gram-negatív baktérium esetében 10 fehérjéből modulárisan felépülő együttes végzi (CcmABCDEFGHI és CcdA - cytochrome $c$ defective vagy DsbD - disulfide bond formation protein).

Az E. coli - mint a Gram-negatív baktériumok tipikus példája - citokróm $c$ maturációért felelős fehérjéi a szigorúan szabályozott aeg46.5 lókusz génjeiről íródnak át. A fehérje-kifejeződés anaerob körülmények között, nitrát és nitrit jelenlétében indukálódik (Choe 1993, Thöny-Meyer 1995, Sanders 2000). 


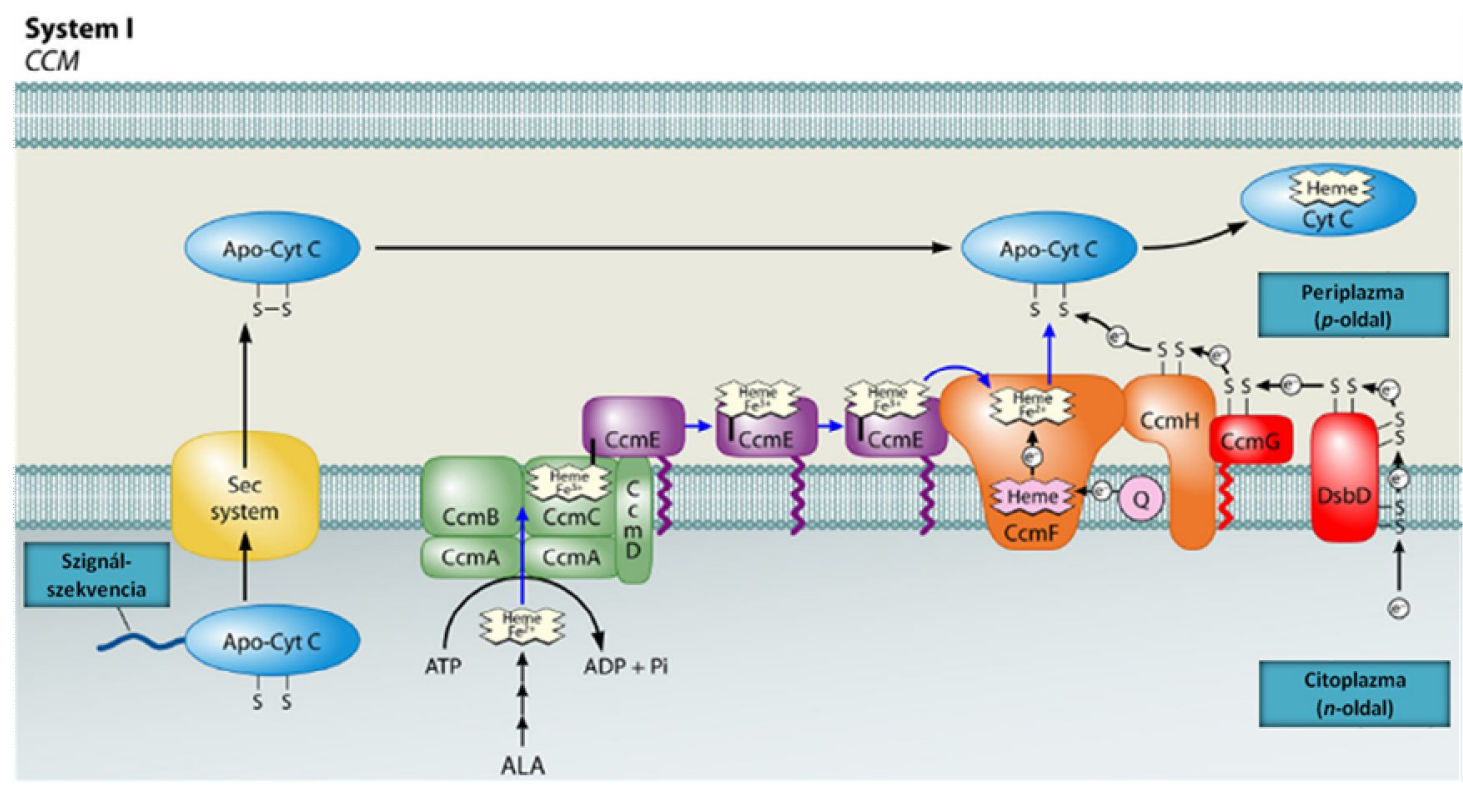

5. ábra. A Ccm maturációs rendszer (Sys I) modellje (Kranz 2009). A modell feltünteti a hem transzport-útvonalát, valamint azt is, hogy a hem milyen oxidációs állapotban van az egyes transzportlépések során. A zöld színnel jelölt fehérjék a hem transzportjáért felelősek, lila színnel pedig a hem chaperon van jelölve. Narancssárga szín jelöli a modult, amely a szintézisért felelős, piros színnel vannak feltüntetve az apocitokróm $c$ redukciójáért felelős fehérjék.

A müködési modulok a következő feladatokat látják el: (i) a hem transzportját és továbbítását (kezelését), (ii) az apocitokróm $c$ előkészítését és a hem kötésre kompetens állapotban tartását, (iii) a tioéter kötés katalízisét.

(i) A CcmABCDE a hem processzálásáért felelős fehérjekomplex, a hem transzportere még nem ismert. A komplexben a CcmA tartalmaz egy nukleotidkötő domént, amely ATP-t hidrolizál, ahhoz, hogy a hem majd a CcmE chaperonra átkerüljön a $\mathrm{CcmC}$ fehérjéről. A CcmC fehérje az ún. hemkezelő (HHP - heme handling protein) fehérjék családjába tartozik. Ezek a fehérjék tartalmaznak egy triptofánban gazdag WWD motívumot, két konzervált periplazmatikus hisztidin aminosavat, amelyek a hem vasának a koordinációjában játszanak szerepet és esszenciálisak ahhoz, hogy a holo-CcmE kialakuljon, azaz a CcmE hem chaperon hemet kössön kovalensen (Schulz 1998).

A legtöbb CcmE fehérje egy HXXXY motívum részeként tartalmaz egy, a működés szempontjából kulcsfontosságú hisztidin aminosavat (kivételes esetben, néhány prokarióta organizmus esetén ez egy cisztein is lehet (Allen 2006)), amely a hem $b$-nek $c$ típussá alakulása útján azt átmenetileg kovalensen köti a 2-vinilcsoport $\beta$-C-atomján keresztül (Lee 2005).

A hem transzlokációja, a hem „feltöltése” a CcmE-re és a CcmABCD komplexnek ezekben játszott pontos szerepe nem ismert még. A komplex CcmA komponense, amint azt 
említettem volt, ATP kötő kazettát tartalmaz. Ilyen kazettát tartalmazó fehérjékről ismert, hogy általában transzporter szerepet töltenek be. Azok az igyekezetek, amelyek ennek a komplexnek a hem transzportálásában játszott szerepét szerették volna igazolni mégsem jártak sikerrel. Mutációval előidézett ATPáz aktivitásvesztés ellenére is kialakul ezekben a törzsekben a holo-CcmE.

Legújabb kísérletek azt mutatják, hogy a CcmA ATP hidrolízise viszont ahhoz kell, hogy a CcmE disszociáljon a CcmABCD komplexről, biztosítva ezáltal a citokróm $c$ érés további lépéseiben a hem ellátmányt (Feissner 2006a). CcmAB mutáns törzsek esetében a CcmC közreműködésével, mint CcmE-specifikus hem liáz, kialakul a holo-CcmE, de a hem továbbítása az apocitokróm $c$ irányába zavart szenved (Christensen 2007).

A Ccm mutánsok képesek periplazmatikus $b$ típusú citokrómok képzésére, ami bizonyítja azt, hogy léteznie kell egy Ccm-független hem transzport mechanizmusnak (is) a citoplazmatikus membránon keresztül.

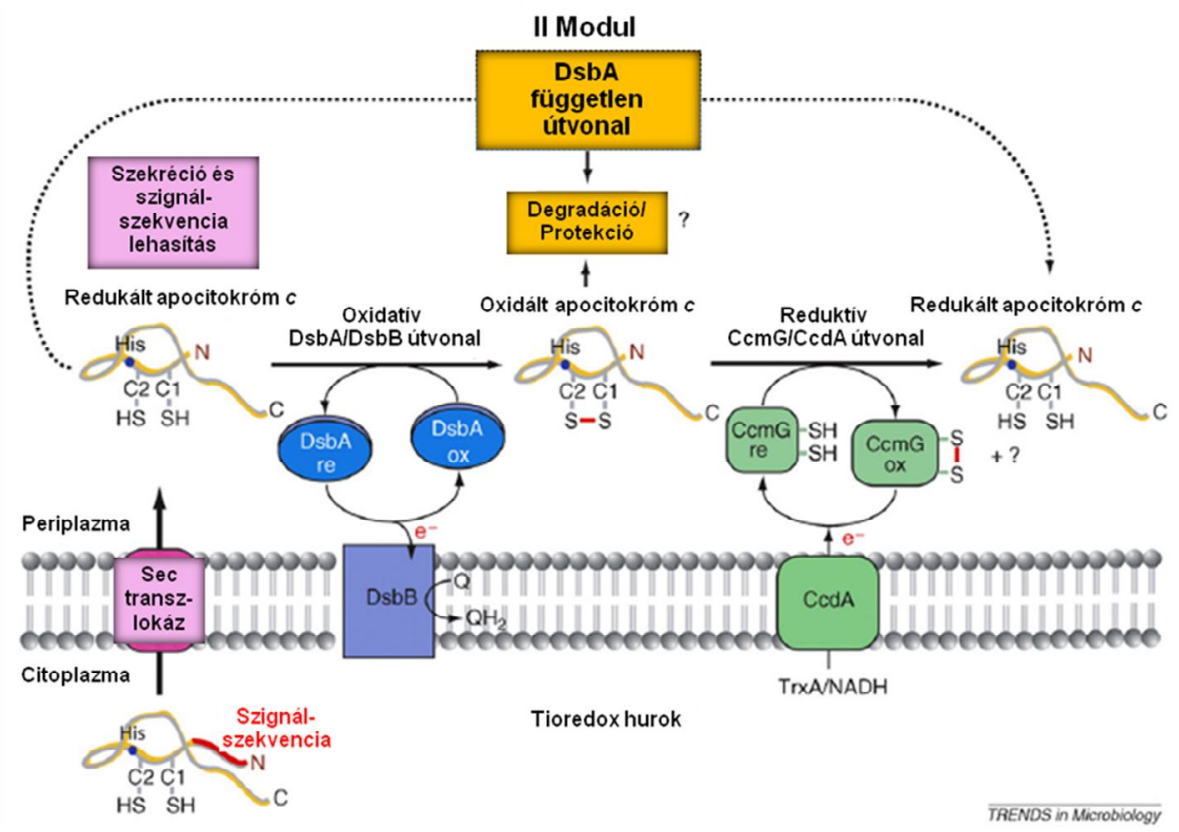

6. ábra. A Ccm maturációs rendszer (Sys I) kettes modulja, az apocitokróm $c$ oxidációjáért és redukciójáért felelős tioredox elemek (oxidatív DsbA/DsbB és reduktív CcdA/CcmG útvonalak), a Sec transzlokációs rendszerrel együtt ábrázolva (Sanders 2010).

(ii) Amint az apocitokróm $c$ a Sec fehérje-transzlokációs útvonalon keresztül a periplazmába kerül, cisztein-oldalláncai oxidálódnak és diszulfidhíd képződik a hemkötő motívum ciszteinjei között egy, a periplazmában müködő oxidatív fehérje folding mechanizmusnak köszönhetően (a DsbA és DsbB fehérjék a felelősek ezért a lépésért). Ennek a mechanizmusnak fehérjét védő szerepe lehet, valószínüleg megakadályozza a fehérjék kicsapódását, ill. a bakteriális többhemes fehérjék esetében valószínűsíthető, hogy 
a helyes tioéter kötéshez diszulfid intermedier kialakulása szükséges (Ferguson 2001). In vivo kísérlettel nem sikerült ugyan kimutatni a diszulfidhíd jelenlétét ezekben a periplazmatikus fehérjékben, de ebben a térrészben fennálló körülmények valószínűsítik képződésüket, ami azt jelenti, hogy később az érés során ezeknek a kulcsfontosságú aminosavaknak hemkötés előtt valamikor redukálódniuk kell. A citokróm $c$ érlelő rendszerének egyes fehérjéi, mint a $\mathrm{CcdA} / \mathrm{DsbD}$, a $\mathrm{CcmG}$, és a $\mathrm{CcmH}$ tartalmaznak ún. tioredoxin-szerü motívumokat (CXXC vagy ún. tiol-redox funkcionális motívum), amelyek ditio-diszulfid oxidoredukciós katalízisük révén képesek a diszulfidhidak redukciójára (5. és 6. ábra) (Thöny-Meyer 2002, Giegé 2008, Sanders 2010).

$\mathrm{Az}$ érési rendszer membránfehérjéi a diszulfidhíd redukciójához az elektront a citoplazmatikus tioredoxin TrxA/NADH rendszertől kapják. Baktériumokban a DsbA/DsbB és a $\operatorname{CcdA}(\mathrm{DsbD}) / \mathrm{CcmG}$ fehérjék egy tioredox hurkot képeznek. Növényekben a CcdA/DsbD és CcmG fehérjék látszólag hiányoznak vagy pedig annyira megváltoztak, hogy szekvencia-hasonlóság alapján már nem ismerhetőek fel (Hamel 2008).

(iii) Ezen modult alkotó elemek száma nagyon változó a különböző organizmusokban, pontos fehérje-összetétele még nem tisztázott a különböző szervezetek esetében. E. coli-ban ezt a modult a CcmF és CcmH fehérjék alkotják, $R$. capsulatus-ban a CcmF és $\mathrm{CcmH}$ mellett müködik egy $\mathrm{CcmI}$ fehérje is. Növények esetében, mint például az Arabidopsis thaliana mitokondriumában, a $\mathrm{CcmF}$ fehérjét három különálló fehérje képviseli: a $\mathrm{CcmF}_{\mathrm{N} 1}, \mathrm{CcmF}_{\mathrm{N} 2}, \mathrm{CcmF}_{\mathrm{C}}$ és ezek mellett a $\mathrm{CcmH}$ fehérje változatlanul a modul része (Hamel 2008). E. coli-ban a $\mathrm{CcmH}$ egy fúziós fehérje, amely tartalmazza a más organizmusban önállóan müködő CcmI C-terminális régióját. Az Arabidopsis thaliana mitokondriumából, úgy tünik, hogy a $\mathrm{CcmI}$ homológja teljesen hiányzik. A CcmI két doménből álló chaperon fehérje, amelynek van egy N-terminális membránban ülő (CcmI-1) és egy szolubilis periplazmatikus doménje (CcmI-2). Ez utóbbi rendelkezik egy ún. tetratrikopeptid (TRP) motívummal, amelynek a fehérje-fehérje kölcsönhatásokban van szerepe. A CcmI-1 minden citokróm $c$ éréséhez szükséges alegység, míg a CcmI-2 csak a Cterminálisával a membránban horgonyzott $c_{1}$ citokróm érésében fontos, azon organizmusokban, ahol a CcmI jelen van. A CcmF membránfehérje, amely a maga triptofán-gazdag WWD motívumával és esszenciális hisztidin aminosavaival egy feltételezett „,hemkezelö” fehérje. Az E. coli esetében a CcmF a holo-CcmE-vel és a CcmHval együtt immuno-precipitálódik, viszont az apocitokrómmal nem. A holo-CcmE és a CcmH között nem észlelhető közvetlen kapcsolat.

A modulok müködése révén a citokróm $c$ érés két lépésre osztható folyamat. Első 
lépésként, a CcmABCD fehérjék közremüködésével, kialakul az oxidált hemet kötő holoCcmE komplex. A második pedig a tulajdonképpeni citokróm $c$ szintetáz lépés. Ebben a lépésben a $\mathrm{CcmF}$ és $\mathrm{CcmH}$ fehérjék újraredukálják a hemet és az apocitokrómot a hem közelségébe hozva beépítik a hemet.

\section{Ccs poszttranszlációs érési rendszer}

A Ccs (citokróm $c$ szintézis), más megnevezéssel Sys II (7. ábra) rendszer a következő élőlényekben fordul elő: Gram-pozitív baktériumokban (pl. Bacillus subtilis), néhány Gram-negatív baktériumban ( $\beta, \delta, \varepsilon$ proteobaktériumok), cianobaktériumokban, növények kloroplasztiszaiban és algákban.

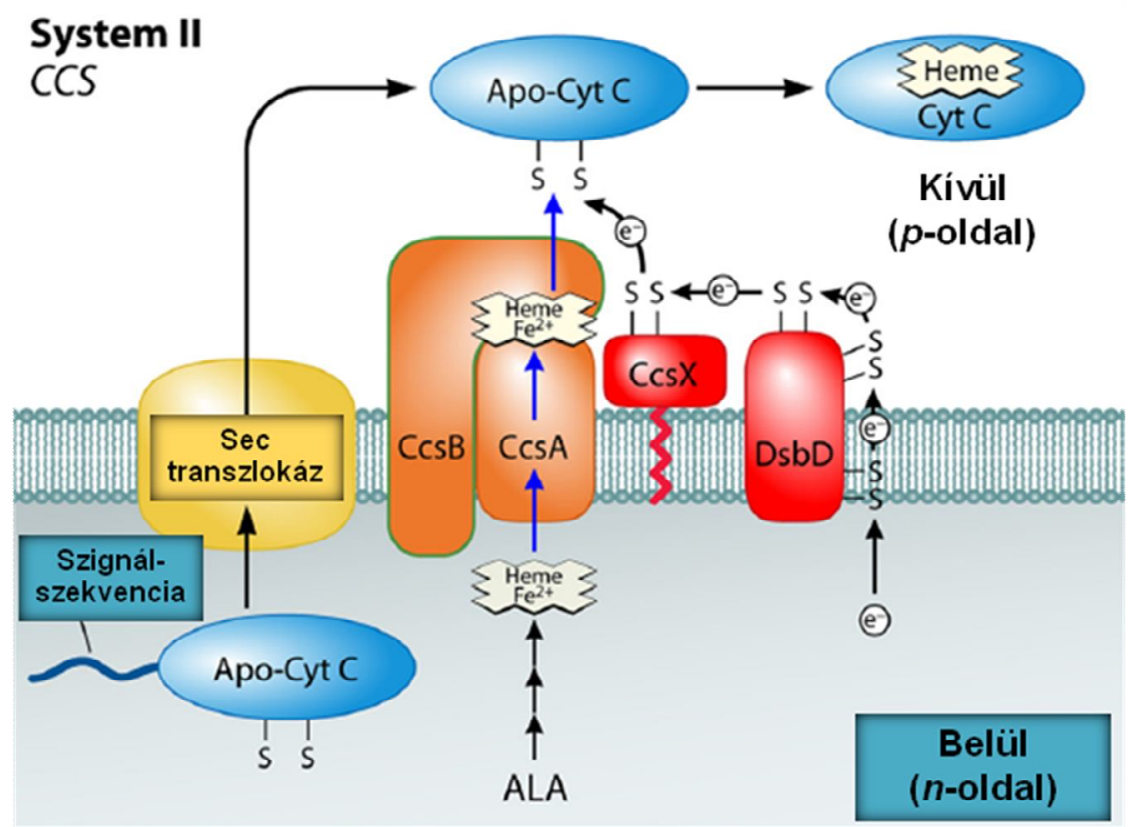

7. ábra. A Ccs maturációs rendszer (Sys II) modellje (Kranz 2009). A modell feltünteti a hemtranszport útvonalát és a hem oxidációs állapotát a transzport során. Narancssárga szín jelöli a modult, amely a szintézisért felelős, piros színnel vannak feltüntetve az apocitokróm $c$ redukciójáért felelős fehérjék.

Ez a rendszer felelős a mitokondriális és bakteriális $b c_{1}$ komplex $c_{1}$ citokrómjával analóg tilakoidális $f$ citokróm éréséért. Az $f$ citokróm a $b_{6} f$ komplex $c$ típusú citokrómja, amely $\mathrm{CXXCH}$ hemkötő motívumot tartalmaz, viszont a hem hatodik koordinációs kötése nem egy metioninnal, hanem a polipeptidlánc $\mathrm{N}$-terminális végével jön létre. Az érést végző Sys II egy egyszerübb rendszer, mint a fent megismert $\mathrm{Ccm}$, csupán négy fehérje játszik benne szerepet (Hamel 2009, Kranz 2009). A hem kezelését és a holocitokróm $c$ szintézisét általában két fehérje, a CcsB és CcsA, de esetenként ezek fúziója nyomán csak egy fehérje, a CcsBA végzi. A Ccs rendszer kisebb affinitással köti a hemet, mint a Ccm. A Ccs rendszernek is van egy, a „heme handling protein” családba tartozó, WWD domént és 
konzervált hisztidineket tartalmazó transzmembrán fehérjéje, a CcsA, amelynek szerepe a redukált hem védelme és kézbesítése a sztróma/citoszól felől a tilakoid lumen/periplazma felé. Az apocitokróm $c$ cisztein-oldalláncainak redukálásáért a $\mathrm{DsbD} / \mathrm{CcdA}$ fehérje felelős, amelyet egy $\operatorname{Ccs} X$ tioredoxin-szerü fehérje közremüködésével valósít meg (Feissner 2006b). Ebben a rendszerben a CcsA fehérje által közvetített hem és az apocitokróm $c$ CXXCH motívumának a közelsége lehetővé teszi a tioéter kötés kialakulását (Kranz 2009).

\section{CCHL poszttranszlációs érési rendszer}

A CCHL (citokróm $c$ hem liáz vagy holocitokróm $c$ szintetáz), más megnevezéssel Sys III rendszer (8. ábra) gombákban, gerinctelenekben, gerincesekben, néhány állati egysejtüben és zöld algák mitokondriumában található (Kranz 2009).

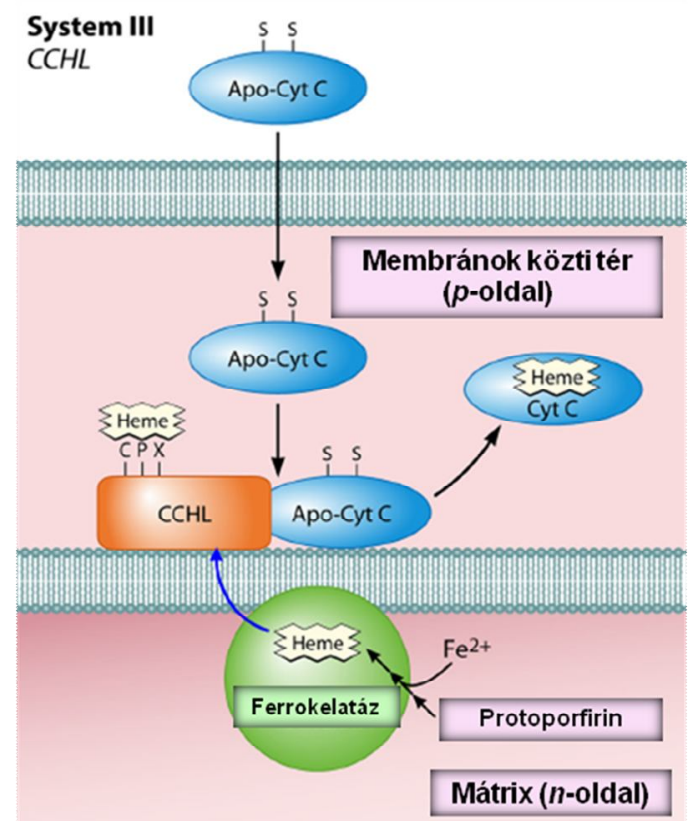

8. ábra. A CCHL maturációs rendszer (Sys III) modellje (Kranz 2009). A modell feltünteti a hem szintézisének utolsó lépését és a hem vélt oxidációs állapotát is a transzport során. Narancssárga szín jelöli a modult, amely a szintézisért felelős, azaz a CCHL enzimet.

Gombákban végzett genetikai elemzés nem mutatott ki a másik két rendszerhez hasonló komponenseket. Ebben a rendszerben egy fehérje végzi az érlelést, így ez a feladat megtévesztően egyszerünek tünhet. Gombák esetében például két változata is előfordul az enzimnek, ezekben az organizmusokban a két mitokondriális $c$ típusú citokrómnak külön érlelő enzime van.

Az élesztőből származó CCHL és emlős (pl. ló) citokróm $c$ génjét együtt kifejezve E. coli-ban érett, a natívval mindenben megegyező citokróm $c$-t lehet előállítani. Ez a tény igazolja, hogy valóban csak a CCHL fehérje közremüködése elegendő a hem kovalens 
kötésére és a citokróm $c$ feltekeredésére. A heterológ expresszió esetén a két fehérje ugyanabban a térrészben, a baktérium citoplazmájában expresszálódik, tehát a sikeres érés önmagában nem szolgáltat információt a hem és az apocitokróm $c$ transzportjáról, annak mechanizmusáról a mitokondriumban.

Ennek az egy-fehérjés érlelő rendszernek a kialakulása egy szubsztrát-specifikációs folyamatnak lehet az eredménye. Míg a prokarióták rendszerei sokféle funkciójú és sokféle foldinggal, esetleg több hemmel rendelkező citokrómok „hadát” érlelik, amelyek mindegyikénél biztosítani kell az éréshez szükséges feltételeket, addig a mitokondriális rendszerben lehetőség nyílt arra, hogy a csupán két $c$ típusú citokrómnak kialakuljon a saját érlelő fehérjéje, sőt egyes esetekben a kettőnek egyetlen érlelő enzime (Allen 2008).

\section{Más poszttranszlációs modifikációs rendszerek}

Egyéb maturációs rendszerekről is említést kell tenni, hogy a jelenlegi ismeretek szerint teljes képet lehessen alkotni a $c$ típusú citokrómok éréséről. Ezek a kivételes rendszerek általában enyhén módosult vagy más mintázatú hemkötő motívummal rendelkező, esetleg motívummal nem is rendelkező polipeptidláncokhoz kapcsolnak kovalensen hemet.

A CCB (citokróm $c$ bioszintézis) rendszer, más néven Sys IV, cianobaktériumokban és növények kloroplasztiszában, azaz az aerob fototrófoknál fordul elő (Kuras 2007, Lyska 2007). A rendszer a $b_{6} f$ komplexböl a $b_{6}$ citokróm spektrálisan egyedi hemjének, $\left(c_{\mathrm{i}}\right)$ egyetlen ciszteinhez való kötésénél asszisztál. A $c_{i}$ egy atipikus hem, amelynek nincs axiális aminosav-liganduma és a fehérje polipeptidláncának sincs hemkötő motívuma (Kuras 1997, Kurisu 2003, Stroebel 2003). A $c_{\mathrm{i}}$ ezért egy pszeudo $c$ típusú citokróm központnak tekinthető a komplexen belül (Ferguson 2008). A CCB érlelö rendszer is bizonyos szempontból eltér az eddig megismert érlelő rendszerektől, a kovalens hemkötést a membrán negatív oldalán katalizálja, ezért valójában nem tekinthető igazi vagy klasszikus $c$ típusú citokróm-érlelő rendszernek (Kranz 2009).

Egy nem-konvencionális érlelő rendszer (a felsorolásban az V.), amely néhány Gram-pozitív baktériumban és néhány euglénaféle (ostoros egysejtü, mint Trypanosoma és Leishmania) mitokondriumában található, egy olyan egyszeresen kötött hemet tartalmazó $c$ típusú citokrómot érlel, amely egy A/FXXCH hemkötő motívumot tartalmaz (Allen 2004, 2008). Lehetséges, hogy egy teljesen új maturációs rendszer vár felfedezésre, ugyanis ezekben a szervezetekben nem találtak az ismert érlelő fehérjékhez hasonló komponenseket (Fülöp 2009). Valószínünek tartják, hogy a felismerő motívumok és a fehérje érlelő 
rendszerének közös evolúciója révén az érlelö rendszer elemei annyira megváltoztak, hogy homológia-kereséssel már nem ismerhetőek fel (Kranz 2009).

Itt szeretném megemlíteni azt is, hogy baktériumokban vannak olyan változatai is a Ccm érlelő rendszernek, amelyek a $\mathrm{CXXCH}$ hemkötő motívum $\mathrm{CXXXCH}$ és $\mathrm{CXXXXCH}$ módosulatait ismerik fel (Rios-Velazquez 2001, Allen 2006). Az NrfEFG géntermékek, amelyek a Ccm rendszer CcmFGH fehérjéinek feleltethetőek meg, az NrfA nirtit reduktáz ötszörösen koordinált hemjét kötik a polipeptidlánc CXXCK motívumához (Eaves 1998, Hartshorne 2007). A Ccs rendszernek egy változata pedig a hemkötő motívumnak egy $\mathrm{CX}_{15} \mathrm{CH}$ módosulatát ismeri fel (Hartshorne 2007).

\section{A citokróm $c$ érési rendszerek evolúciója}

Érdekes kérdés, hogy mi szükségelteti ezt a sokféle megoldást ugyanannak a feladatnak az elvégzésére. A legegyszerübb megoldást a CCHL képviseli, amely az endoszimbiotikus együttélés következményeként alakulhatott ki az eredetileg $\alpha$ proteobaktériumok $\mathrm{Ccm}$ érlelő komplexéből. A jóval bonyolultabb $\mathrm{Ccm}$ és $\mathrm{Ccs}$ érlelő rendszerek müködését az teszi szükségessé, hogy esetlegesen változó feltételek mellett is redukált hemet kell biztosítani a kovalens kötés kialakulásához, és az is, hogy sokféle szerkezetü és sok esetben többhemes $c$ típusú citokrómokat kell érlelni.

Az evolúció során bizonyos esetekben, főleg állati mitokondriumokban, ez a változó belső környezet megszűnt, a redukált hem nem volt limitáló feltétel többé, a $c$ típusú citokrómok bonyolultsága és száma lecsökkent, s így ezekben az organizmusokban a bonyolult érlelö rendszerek elavulttá és szükségtelenné válhattak. Ezért az evolúció egy egyszerübb és gazdaságosabb megoldást részesíthetett előnyben, amelyben nem kellett egy sorozat fehérjét előállítani és nem volt szükséges ATP sem, ellentétben a $\mathrm{Ccm}$ rendszerrel. Mivel ezekben a sejtekben csak kétféle citokróm $c$ müködik, a sejt számára egyszerübb megoldás, hogy ezeket két specifikus CCHL vagy akár egyetlen enzim érlelje. Ma már nem lehet pontosan megmondani, hogy a két bonyolult rendszer közül melyik lépett színre előbb, de - mivel a Ccs jelen van a cianobaktériumokban - az a feltételezés, hogy ez a megoldás volt jelen az endoszimbiózis során, amely aztán a mai algák kloroplasztiszát eredményezte. A bonyolult és költséges $\mathrm{Ccm}$ rendszer hemmel szembeni nagyobb érzékenysége pl. előnyöket biztosíthat bizonyos környezeti feltételek esetén. A Ccm a Ccs hem igényénél 5x alacsonyabb hemkoncentrációnál is zavartalan müködést tud biztosítani a szervezet számára, így ez a rendszer a környezeti változásokhoz jobb alkalmazkodást tud biztosítani. 


\section{Az apocitokróm $c$ transzlokációja}

Az apocitokróm $c$ transzlokációja a Sys I és a Sys II rendszerek esetében függetlenül történik a hem kovalens kötésétől, azaz olyan esetekben is müködik a transzport és a processzálása az apofehérjéknek, amikor az összeszerelés nem történhet meg. Ez alól kivételt jelent a Sys III érlelő rendszer, ugyanis ebben az esetben a transzportot valamilyen módon az érlelő faktor, azaz a CCHL ellenőrzi. CCHL (cyc3) hiányos törzsből izolált mitokondriumba nem transzlokálódik, pontosabban importálódik, tartósan az apocitokróm c. A fent említett kivételes esetet megmagyarázhatja az, hogy vannak olyan in vitro import kísérletek is, amelyek az apocitokróm $c$ reverzíbilis importját igazolják (Hakvoort 1990).

A CCHL hiányán túl az apocitokróm $c$ importját a módosított hemkötő szekvencia (ahol a ciszteineket szerinek helyettesítik) is befolyásolja. Ennek a változatnak ugyan nem lehetetlen az importja, de nagyon kis hatásfokkal történik ( 5\%). A CCHL ezzel a mutáns szekvenciájú szubsztráttal is képes kölcsönhatásba lépni (Wang 1996), ez a tény azt sugallja, hogy a két cisztein nem kritikus fontosságú a felismerésében. Ellenben, ha ilyen esetben a CCHL-t túltermeltetik, akkor a kötésre inkompetens apocitokróm $c$ importján ez javít, és majdnem 40\%-a importálódik a fehérjének (Dumont 1988, 1991). Ezek a tények arra engednek következtetni, hogy a CCHL-nek nagyon fontos szerepe van az érésen túl az apocitokróm $c$ importjában (ami úgy értelmezhető inkább, hogy a visszatartásában), és hogy az apocitokróm $c$ hemkötő motívuma nem esszenciális ezen folyamat szempontjából. A CCHL fent leírt szerepét érlelő enzimben mutáns gombatörzsekkel végzett kísérletek is igazolják. Azoknál a törzseknél, amelyek képtelenek apocitokróm c-t importálni, az apocitokróm $c$ gyors lebomlása figyelhető meg a citoplazmában (Matner 1982, Dumont 1990).

A fentiek alapján az apocitokróm $c$ külső membránon keresztüli transzlokációjáról és a CCHL-nek az apocitokróm $c$ importjában játszott szerepéről az foglalható össze, hogy az apocitokróm $c$ hemkötés nélkül is, ideig-óráig, kölcsönhatásba lép a CCHL-lel, de akadályozott hemkötés esetén (pl. cisztein-mutáns apofehérje) a transzlokáció reverzíbilissé válik. Az apocitokróm $c$ hemkötés után, azaz holo formájában „csapdázódik” csak az intermembrán térben, és addig adott a lehetőség az apocitokróm $c$ számára, hogy elhagyja az intermembrán teret.

A $c$ és a $c_{1}$ importja különböző útvonalakon történik. Az apocitokróm $c$ nem hordoz N-terminális szignálszekvenciát, ehelyett viszont integráns jellel jut célba a mitokondriális intermembrán térbe. Importja szokatlan útvonalat követ. Ismert, hogy a mitokondriális 
intermembrán térbe kerülő fehérjék mátrixban töltött idejük alatt hősokk fehérjék közremüködését igénylik, amely fehérjék szerepét a $c$ típusú citokróm esetében, az import és az érés közötti időszakban, a CCHL veszi át. NMR spektrális vizsgálatból valóban kiderül, hogy az apofehérje nem mutat túl nagyfokú szerkezeti rendezettséget (Cohen 1974) és cirkuláris dikroizmus (CD) spektruma sem változik hőkezelés hatására (Fisher 1973). Molekuláris részletességgel nem ismert az apocitokróm $c$ importfolyamata, de azt lehet tudni, hogy fiziológiás ionerősségen lipid- és detergens-vezikulákhoz képes kötődni. Az apofehérje membránaffinitása túlmutat egy tipikus perifériás kölcsönhatáson, ugyanis képes spontán beágyazódni a lipidmembránba (Stuart 1990a, Dumont 1996). Sőt, a holocitokróm $c$ is képes destabilizálni a membránt és semleges lipidmembránokon áthatolni (El Kirat 2009).

Ez a membránaffinitása tette lehetővé, hogy a citokróm $c$ egy direkt útvonalat követhessen importja során, mást, mint amilyent az intermembrán térbe kerülő egyéb fehérjék követnek a mátrix és a belső membrán érintésével. Vezikuláris és liposzómás kísérletek azt igazolják, hogy részleges inszerció következtében, amely a lipidösszetételtől is függ, az apocitokróm $c$ belső vizes oldalról elérhetővé válik transz-oldali receptorok számára (Mayer 1995), illetve a membránnal való kölcsönhatása során részlegesen emészthető lesz a külső oldalról hozzáadott, valamint a vezikulába zárt proteázok számára is (Dumont 1984).

Proteoliposzómás (Diekert 2001) és közvetett in organello kísérletek azt bizonyítják, hogy a mitokondriális külső membrán transzlokázának, a TOM-komplexnek (GIP-General Import Pore) bizonyos komponensei, a TOM40 pórusalkotó komponens és a TOM22 receptor fehérje segítik az importot. Amikor a komplex pórusfehérjéje gátolt, az apocitokróm $c$ importja - igaz, csak mérsékelten - de gyengült, míg a Tom22 hiánya lényegesen befolyásolta az import hozamát (Wiedemann 2003).

\section{A kovalens kötés szerepe ezekben a fehérjékben}

Általános nézet szerint a kovalens kötésnek a fehérje stabilitásának növelésében van szerepe, ezáltal a $c$ típusú citokrómok egyrészt nehezebben veszítik el hemjüket, mint a globinok, ill. más citokrómok, másrészt a denaturációval szemben is védettebbek (Arnesano 2000, Allen 2003a, 2005b). A korábbi feltételezés, hogy ezáltal a fehérjék alkalmasak a redoxpotenciáljuk finomhangolására, valószínütlennek tünik (Barker 1999, Allen 2005b, Bowman 2008), ugyanis olyan mutáns citokrómok, amelyek elveszítették akár mindkét kovalens kapcsolatukat a hemjükkel, minimális redoxpotenciál-változást szenvedtek 
(Tomlinson 2000a, b). A kovalens kötés ugyanakkor lehetővé teszi a sokkal magasabb hem polipeptidlánc arányt is, így akár 34 hem is kapcsolódhat egyetlen lánchoz (Stevens 2004), tehát a hem kovalens kötése gazdaságos polipeptidlánc felhasználást enged meg. Van olyan többhemes $c$ típusú citokróm $\left(c_{3}\right)$, amelyben egyetlen hemre csupán 25 aminosav jut. Magas hemarány esetén a kovalens kötés szoros, térben közeli és jól meghatározott hemelrendezést eredményezhet (Barker 1999).

\section{Nem-enzimatikus és spontán érési ismeretek az irodalomból}

Barker és mtsi. (1993, 1995), illetve Allen és mtsi. (2003b) különböző $b$ típusú citokrómok $\left(b_{562}, b_{5}\right)$ szekvenciáját módosították a hem vinilcsoportjának közelében ciszteinre, azért, hogy a tioéter kötés kialakulásának feltételeit vizsgálhassák, in vivo nemenzimatikus, in vivo enzimatikus és in vitro spontán körülmények között. Ismert, hogy a hemet kovalensen nem kötő citokrómoknak az apofehérjéi is a holohoz hasonló 3D szerkezetet vesznek fel. A feladatra kiválasztott $b$ típusú citokrómok szekvenciájának olyan pontjait módosították ciszteinekre, amelyek a feltekeredett fehérjében közel helyezkednek el a hem vinilcsoportjaihoz. Az in vitro vagy in vivo körülmények között, enzimatikus közremüködés nélkül érő citokrómoknak vegyes spektrumú populációja alakult ki; feltételezhető, hogy a hem sztereospecifikus orientációjának hiányában a kofaktor más más pozícióban épült be. Az in vivo enzimatikusan érő citokrómok is eltolódott spektrumúak voltak, amelyekre azt a magyarázatot adták, hogy a kovalens kötés kialakult ugyan, de a fehérje nem rendelkezett a natív térszerkezettel. Következtetésként levonható, hogy a hem vinilcsoportjainak és a cisztein-oldalláncoknak a közelsége folytán a két fél között spontán is kialakulthatnak kovalens kapcsolatok, amennyiben a megfelelő redukáló körülmények fennállnak.

Az citokróm $c$ érésnek és körülményeinek vizsgálatára hasonló kísérleteket végeztek Daltrop és mtsi. (2002, 2003a, b) termofil prokarióta, illetve eukarióta és mezofil bakteriális eredetü citokróm $c$ fehérjékkel is. Az eukarióta és a mezofil bakteriális esetekben az érés 48 órás időtartama alatt egy 40:60 arányú $b$ és $c$ típusú keveréket kaptak. A Hydrogenobacter thermophilus termofil baktérium vad és mutáns $c_{552}$ citokróm változatainak in vitro spontán érése jelentősen nagyobb hozamot mutatott. A Hydrogenobacter thermophilus apocitokrómjának sajátossága, hogy hem nélkül is képes megfelelően feltekeredni, így az apocitokróm $c$ térszerkezete kialakít egy hemkötésre alkalmas zsebet. Kovalens kötés elött kialakul a hem és az apocitokróm $c$ stabil komplexe, amely megnöveli a hem kovalens kötésének az esélyét, minek következtében a fehérje-folding is felgyorsul (Sinha 1998). Ez 
megmagyarázza a szokatlanul nagy hozamot, ami a spontán érés során észlelhető. A fehérjéről korábban már ismeretessé vált, hogy az E. coli citoplazmájában enzimatikus katalízis nélkül nagyon kedvező hozammal érik (Sanbongi 1991). Ez akár spontán érés is lehet, mivel nem azonosítottak az érésben közremüködő egyéb aspecifikus faktort. A Hydrogenobacter thermophilus $c_{552}$ citokrómjának nem-enzimatikus érését citokróm $c$ érlelö-apparátusban hiányos törzsben is igazolták (Sinha 1998).

\section{A mitokondriális $c$ és $c_{1}$ citokrómokat érlelő CCHL enzim(ek)}

Bizonyos organizmusokban, mint pl. az élesztőben a kétféle citokróm $c$-nek megvan a saját érlelő enzime: CCHL a $c$-nek és $\mathrm{CC}_{1} \mathrm{HL}$ a $c_{1}$-nek. Igaz, hogy a CCHL képes bizonyos mértékig átvenni a $\mathrm{CC}_{1} \mathrm{HL}$ szerepét, de hatásfoka ( 5\%) elmarad jócskán attól, amit az eredeti enzim biztosítani tud. CCHL-hiányos mutáns törzsből teljes mértékben hiányzik a citokróm $c$, ami lehetséges, hogy a $\mathrm{CC}_{1} \mathrm{HL}$ enzim szubmitokondriális lokalizációjából vagy a felismerő szekvenciák hiányából adódik. Magasabbrendủ szervezetek esetében, mint az emberben is, mind a két fehérjét egy enzim érleli (Steiner 1996, Bernard 2003).

\section{A CCHL azonosítása és poszttranszlációs mitokondriális importja}

A hem liáz génjét (cyc3) 1987-ben azonosították (Dumont 1987). Egy Saccharomyces cerevisiae genomdarab, amely tartalmazott egy $\sim 0,9$ kilobázis hosszúságú nyitott leolvasási keretet, képes volt funkcionálisan kiegészíteni egy citokróm $c$ érésben deficiens $c y c 3^{-}$élesztő törzset. Erről a génszakaszról átíródó 269 aminosavat tartalmazó fehérje végzi az élesztő két citokróm $c$ izoformájának érését, amelyet aztán citokróm $c$ hem liáznak, CCHL-nek, neveztek el (ezt a nevet használták eredetileg az élesztő mitokondriális kísérletekben, de az enzim más néven is ismert, mint holocitokróm $c$ szintetáz, amely név jobban fedi a fehérje tényleges funkcióját).

A CCHL génje szintén nukleárisan kódolt, importja - akárcsak az apocitokrómé eltér attól az útvonaltól, amit az intermembrán térbe kerülő fehérjék importjuk során végigjárnak, noha ugyanazokat a külső membránreceptorokat használja a liáz is. A CCHL importjának néhány közös jellemvonása van a mátrixba vivő általános importútvonallal, de mátrixspecifikus szignál hiányában a fehérje az import pórust az IMS szintjén elhagyja. A CCHL fehérje IMS importja során szelektíven használja a külső membrán import- és receptor-komplexét (GIP - General Import Pore). A CCHL importja egy nem-konzervatív útvonalat képvisel, ami egy példája annak, hogy a külső és a belső membránok fehérjeimport komplexei külön is müködőképesek (Lill 1992). A külső membrán 
transzlokáza szükséges és elegendő is ahhoz, hogy a CCHL importálódni tudjon az IMS-be. A CCHL importjában nincs szerepe a belső membránnak, a belső membránpotenciáltól és ATP hidrolízistől független módon importálódik.

\section{A CCHL szerkezete}

Aminosavlánca nem tartalmaz tipikus mitokondriális célszekvenciát az Nterminálisán, csak egy 60 aminosavnyi integráns szignált azonosítottak a fehérje harmadik negyedében, amely energia-független transzportot biztosít. Ez a C-terminális szakasz tartalmaz egy, a Pfam 01265 csoportba tartozó, konzervált szekvenciát is, amelyről azt feltételezik, hogy fontos a müködésük szempontjából. A CCHL enzimek N-terminális régióikon tartalmaznak egy vagy két $\mathrm{CPX}$, ún. hemszabályozó motívumot $(\mathrm{X}=\mathrm{V}, \mathrm{M}, \mathrm{I}, \mathrm{L})$, amely motívum egy tranziens hemkötő helyet jelent.

A belső szignál elegendő a fehérje azonosításához és a transzporthoz is. A transzlokációhoz a hajtóerőt az biztosítja, hogy a CCHL nagyaffinitású kölcsönhatásokat létesít az IMS bizonyos komponenseivel. Ez az integráns célszekvencia az eddig ismert és vizsgált CCHL szekvenciákban (N. crassa, Schizosaccharomyces pombe, S. cerevisiae, Candida albicans, Homo sapiens, Mus musculus, Caenorhabditis elegans) erösen konzervált, és nagyszámú töltött aminosavjának köszönhetően ez egy hidrofil tulajdonságú szignál (Diekert 1999).

A CCHL elsődleges szekvenciája ismert csak, 3D térszerkezetének meghatározása a fehérje sikeres tisztításáig és kristályosításáig várat magára. Az ismert CCHL szekvenciák $30 \%$ aminosav azonosságot mutatnak, és az eddigi ismeretek alapján úgy tủnik, hogy nincsenek bakteriális ortológjaik (Hamel 2008). Az eukarióta liázok szerkezetéről csak indirekt proteáz-emésztési vizsgálatból van néhány információ. Nem-tisztított élesztő CCHL és $\mathrm{CC}_{1} \mathrm{HL}$ fehérjék tripszinnel való emésztésének egy 21 és egy 25 kDa-os fragmentum az eredménye. Ezek a fragmentumok proteáz-emésztéstől védett, feltekeredett szakaszai lehetnek a fehérjéknek, ugyanis denaturáció után ezek a fehérjedarabok is hozzáférhetővé válnak a tripszin számára és teljesen elemésztődnek (Steiner 1995). A hem az érés során kölcsönhatásba lép a liázokkal, sőt a $\mathrm{CC}_{1} \mathrm{HL}$ kísérleti példájából azt is tudjuk, hogy a hemnek proteolitikus védő szerepe van. Hem jelenlétében a tripszinnel kezelt $\mathrm{CC}_{1} \mathrm{HL}$ intakt marad, míg hiányában 25 kDa méretü darabra hasad (Steiner 1996).

\section{A CCHL lokalizációja a mitokondriumokban}

A CCHL szolubilis fehérje, amely a mitokondriális intermembrán térben 
helyezkedik el. A CCHL szubmitokondriális elhelyezkedése nem ismert pontosan, de az organellum frakcionálási kísérletei azt mutatják, hogy a belső membrán külső oldalához van tapadva (Nicholson 1988, Steiner 1995). Ugyanakkor nem kizárt az sem, hogy időszakosan a külső membránhoz asszociált, vagy pedig az átmenetileg kialakuló és megszünő kontaktzónák miatt a belső membránhoz tapadt fehérje az organellum felületéhez közel kerül (Wang 1996). Triton X-100 hatására szolubilizálódik, míg magas sókoncentráció hatására együtt frakcionálódik a belső membránnal (Enosawa 1986). Ez az információ csak úgy egyeztethető össze az enzimnek az apocitokróm $c$ importjában betöltött szerepével, ha elsősorban az apocitokróm csapdázásában mintsem a transzlokációjában játszik szerepet (Dumont 1996).

\section{A CCHL feltételezett szerepe a citokróm c érésben}

A CCHL szintetáz katalitikus mechanizmusa nem ismert pontosan, de azt lehet tudni, hogy kölcsönhatásba lép mind a hemmel, mind az apocitokrómmal. Az eddigi, a CCHL enzimaktivitására irányuló indirekt, illetve részlegesen tisztított enzimmel végzett vizsgálatok nem adták meg a választ a müködési mechanizmusra vonatkozóan. Legalább háromféle „forgatókönyv” lehetséges az enzim és szubsztrátjai közötti interakciókra a kötést megelőzően (Dumont 1996):

1. Az enzim elöbb a hemmel lép kölcsönhatásba.

2. A CCHL előbb az apocitokrómmal lép kölcsönhatásba, amelynek konformációváltozását idézné elő (Barker 1993).

3. A hem előbb az apocitokrómmal lép kölcsönhatásba, aminek következtében az apocitokróm $c$ felvesz egy részlegesen feltekeredett konformációt, amit látható tartományban mért abszorpciós és UV tartományban mért CD spektrális változásokkal támasztanak alá (Dumont 1994). A CCHL-nek lehet a feladata az, hogy ezt a kölcsönhatást egy olyan optimális konformációvá alakítsa, amelyben a proximitás miatt a kovalens kötés kialakulásának sebessége megnő (Ferguson 2008).

A CCHL-ek CPV motívumáról spektrálisan bizonyított a hemmel való tranziens kölcsönhatás, hemszabályozó motívumot tartalmazó peptidek és a hem közötti kölcsönhatás révén. Mutáns reguláló motívumokkal végzett kísérletekből az derül ki, hogy a cisztein a hem kötésének, a prolin a kölcsönhatás elösegítésének szempontjából kritikus fontosságú (Zhang 1995). Vannak más funkciót betöltő fehérjék is, amelyek tartalmazzák ezt a motívumot. Ezeken keresztül szabályoz a hem pl. transzkripciós faktorokat, transzláció iniciációt, illetve még fehérje importot is (Padmanaban 1989). A CCHL-ek esetében csak 
közvetett bizonyítékok támasztják alá azt, hogy ezek a fehérjék a motívumon keresztül kötik a hemet. Közvetett, in vivo kísérletekből kiderül, hogy ennek a motívumnak a megváltoztatása ugyan befolyásolja a hemkötést, de az így sem szünik meg teljesen (Steiner 1996). A szekvencia jelentősége nem egyértelmü a hem liáz müködésének szempontjából, ismerve a mutációs kísérleteket és azt, hogy vannak olyan CCHL-ek, amelyek nem tartalmazzák ezt a motívumot. Ezek alapján az mondható, hogy a motívum nem alapvetően fontos a müködés szempontjából (Hamel 2008). Annak megértése, hogy a hem liáz hogyan lép kölcsönhatásba a hemmel választ adna arra, hogy az enzim, mint valódi katalizátor müködik-e az érés során vagy pedig csupán egy „állványzatot” képez annak érdekében, hogy az apocitokróm $c$ a hemet sztereospecifikusan megköthesse és a reaktív csoportokat térben egymás közelébe hozza. Az élesztők kétféle CCHL enzimének a szükségessége pedig azt sugallja, hogy nem csupán a $\mathrm{CXXCH}$ motívum az, ami a szubsztrát-specificitás biztosításához kell, hiszen a CXXCH motívum mindkét enzimben megtalálható.

A citokróm $c$ és a citokróm $c_{1}$ különböző import útvonalakat követnek. Az előbbi fehérje, mint azt már említettem, nem hordoz levágható célszekvenciát, ellentétben a $c_{1}$ gyel, de ha ez utóbbinak a szignálpeptidjét viseli, akkor az import útvonala is ennek megfelelően módosul, viszont így egyik liáz sem képes érlelni (Stuart 1990b). Ezt értelmezve az mondható, hogy a CCHL tekintetében valószínü, hogy az apocitokrómnak a megfelelő orientációban kell az enzim felé mutatkoznia ahhoz, hogy az érés megtörténhessen. A $\mathrm{CC}_{1} \mathrm{HL}$ közremüködéséhez pedig bizonyos felismerö-szakaszok/jelek hiányoznak a normális körülmények között nem-szubsztrát fehérje processzálásához (Dumont 1996). Ez a mechanizmus ellentétben áll az I és II rendszerrel, amelyek tipikusan a CXXCH motívumot ismerik fel és fogadják el specifikusnak.

Mitokondriumokkal és mitokondriális külső membránvezikulába zárt, a CCHL-t funkcionálisan helyettesítő, antitestekkel végzett kísérletek a CCHL importban játszott ún. transz-oldali receptor-szerepét is kimutatják (Mayer 1995). Az apocitokróm c CCHL-lel való kölcsönhatásának szekvencia-követelménye úgy tünik, hogy a hemkötő motívumot körülvevő szakaszra korlátozódik (Veloso 1984, Tong 1998).

Élesztőben azonosítottak egy Cyc2p-nek nevezett redoxfehérjét (a cyc2 gén termékét), amely funkcionálisan köthető az éréshez (Matner 1982). Ez egy NADPH függő flavoprotein, amelynek közremüködésére biokémiai bizonyítékok vannak in organello (Nicholson 1989) és élesztő mitoplasztokkal (Tong 1998) végzett kísérletekből. A mitokondriális intermembrán tér oxidatív környezetében a CCHL katalizálta érésben a flavoproteinnek az apocitokróm és/vagy hem redukálásában van szerepe. A redoxfehérje az 
import hatékonyságát növeli, de nem nélkülözhetetlen az importban. Hiánya esetén a citokróm $c$ szintje lecsökken, a $c_{1}$-re gyakorolt hatása szembeötlőbb (ezek a törzsek ún. légzési deficiens fenotípust mutatnak). Az apocitokróm $c$ ciszteinjei redukált állapotban tartásának mechanizmusa nem ismert, ezért nem kizárható az sem, hogy léteznek kimondottan a diszulfidhíd képződésére és tiol-redukcióra alkalmas útvonalak a mitokondriumban (Hamel 2009). A Cyc2p jelenléte azon III-as rendszerekre korlátozódik, ahol a két citokróm $c$-nek külön liáza van, mint pl. a gombáknak. Magasabbrendű szervezetekben, pl. emberben is egy liáz van, a HCCS, és ezekben nem találtak Cyc2p szerkezeti homológokat. 


\section{Célkitüzések}

Kutatásaink a citokróm $c$ mutánsok előállításával és jelölésével annak a kérdésnek a tisztázására irányulnak, hogy hogyan szabályozza a fehérje a redox-reakciók sebességét. Ezt olyan fehérjén, illetve fehérjekomplexen végzett elektrontranszfer kísérletekkel vizsgáljuk, amelyekben különböző kísérleti paramétereket változtatunk meg. Főként az elektrondonor és -akceptor relatív pozícióját, miáltal módszeresen vizsgálható egyrészt az elektrontranszfer útvonal hosszának, másrészt a donor és akceptor közötti fehérjemátrix molekuláris szerkezetének a hatása az elektrontranszferre.

Az elektrontranszfer vizsgálatainak eredményeit dolgozatomban nem részletezem, ez egy másik dolgozatnak a témája, de az ehhez köthető mutagenezis munka szerves része a kutatási témámnak, ezért annak ismertetésére részletesen kitérek.

A citokróm $c$ mutánsok előállítása megbízhatóan müködő és nagy hozamot biztosító expressziós rendszert igényel. A jó expressziós rendszer, valamint egy hatékony fehérjetisztítási procedúra kidolgozása elengedhetetlen ahhoz, hogy nagy mennyiségben álljon rendelkezésre a kívánt fehérje. A munka ezen részének célja a holocitokróm $c$ mutánsok megbízható és hatékony előállításának a kidolgozása volt.

Az eukarióta citokróm $c$ mutánsoknak sikeres heterológ koexpressziója az érlelőenzimmel felvetette az igényét annak, hogy az érést magát önálló kutatási területként vizsgáljuk. Heterológ gazdában a sikeres in vivo érési kísérletek nem adhatnak választ arra vonatkozóan, hogy melyek azok a minimális kísérleti körülmények, amelyek sikeres éréshez vezethetnek. Ennek a kérdésnek a megválaszolására kontrollált in vitro vizsgálatok kellenek. A sikeres in vitro rekonstitúciós kísérlet előfeltétele, hogy az érlelő enzim tisztított, aktív formája rendelkezésre álljon, ehhez pedig egy tisztítási procedúrának a kidolgozása volt a cél. Célul tüztük ki tehát a CCHL enzim heterológ expresszióját és tisztítását, különös tekintettel arra, hogy a szakirodalom tanúsága szerint ezt a fehérjét még nem tisztították ki, ezért az elsődleges szekvenciáján túl semmilyen szerkezeti ismeretünk nincs róla.

Célul tüztük ki a CCHL fehérje szerkezetének és müködésének, illetve a szubsztrátjaival (hem és apocitokróm $c$ ) való kölcsönhatásának a tanulmányozását. Mivel a fehérje aktív formában való előállítása meglehetősen kis hatásfokú, egyelöre kristályosításhoz vagy NMR szerkezet-meghatározáshoz elegendő mennyiségre nem gondolhatunk. Ezért főként spektroszkópiai mérések elvégzését tűztük ki célul a tisztított fehérjén önmagában, illetve szubsztrátjaival együtt. A CCHL szekvenciájának 
felhasználásával pedig homológia-keresés és in silico szerkezet-predikciós számolások segítségével kívántunk ismereteket szerezni a fehérje várható szerkezetéről és tulajdonságairól.

$\mathrm{Az}$ expressziós kísérletek során kiderült, hogy E. coli-ban akkor is képződik holocitoktróm $c$ - igaz, meglehetősen kis hatásfokkal - ha a sejt csak az apocitokróm $c$ génjét tartalmazza, a CCHL génjét nem. Ezt a nem-enzimatikus - az egyszerüség kedvéért spontán - érésnek nevezett jelenséget is alaposabb vizsgálat alá kívántuk vonni, hiszen a nem-enzimatikus érés lehetősége és az így képződött citokróm $c$ összehasonlítása az enzimatikusan érlelt citokrómmal az enzimatikus érés körülményeiről és annak mechanizmusáról is elárulhat fontos részleteket. 


\section{Anyagok és módszerek}

\section{Citokróm $c$ és CCHL fehérjéket túltermelő plazmidkonstrukciók és baktériumtörzsek}

A DNS-manipulációs technikákat az általános gyakorlatnak megfelelően hajtottuk végre, amint az a laboratóriumi tankönyvekben le van írva (Sambrook 1989, Ausubel 1996). A vad típusú ló citokróm $c$ expressziójára szolgáló pBPHCyc1-YCyc3 (Dolgikh 1998) eredeti plazmid Dr. Dolgikh ajándéka volt Moszkvából (Institute of Bioorganic Chemistry, Russian Academy of Sciences, Moscow). A vad típusú és a mutáns citokróm $c$-k hozamának növelése érdekében ennek a plazmidnak a cyc1 (citokróm c) és cyc3 (CCHL) génjeit tartalmazó kétcisztronos kazettáját PCR-amplifikáció után (5' végi: 5' ACACAGGAACTCGACCATGG-3' és 3' végi: 5'-TTAAGGGGCGGAGGACGAA-3' primerekkel) klónoztuk a pBAD24 plazmidba (Guzman 1995). Így a gének egy arabinózindukálható $\left(\mathrm{P}_{\mathrm{BAD}}\right)$ promóternek kontrollja alá került. A későbbi könnyebb manipuláció érdekében a $c y c 1$ gén elejére bevittünk egy $N c o$ I hasítóhelyet az 5' végi PCR primerrel. Az NcoI és SmaI emésztett PCR fragmentumot a hasonló restrikciós endonukleáz végekkel rendelkező pBAD24 plazmidba klónoztuk, így kaptuk a pBAD24HCyc1-YCyc3, majd a cyc3 génben jelen levő $N c o I$ hasítóhely kiütése után a pBAD24HCyc1-YCyc3NcoI konstrukciót. A hasítóhely elrontásához az 5'-AGTGGAGTCTATGGTGCAGG-3' előreirányuló és az 5'-CTGCACCATAGACTCCACTG-3' visszairányuló PCR primereket használtuk.

A nem-enzimatikusan érő citokróm $c$ expressziójának céljából szintén $\mathrm{P}_{\mathrm{BAD}}$ promóter hajtotta konstrukciót állítottunk össze. Az apocitokróm $c$ későbbi tisztításának érdekében a gén 3' végéhez PCR-amplifikációval Strep II affinitás peptidet fuzionáltunk a következő 3' végi primerrel: 5'-TTACTTTTCGAACTGCGGGTGGCTCCAGTTCTTGTCGTCGTCGTCTTCGTTAGTAGCC-3'. Az 5' végi primernek pedig a fent megjelölt NcoI hasítóhelyet hordozó primert használtuk. A PCR fragmentumot NcoI és SmaI restrikciós endonukleázokkal emésztettük, és a hasonló restrikciós endonukleáz végekkel rendelkező pBAD24 plazmidba klónoztuk, amely által a pBAD24Cyc1-STII konstrukciót kaptuk.

$\mathrm{Az}$ érlelőenzim (CCHL) kifejezésére egy $\mathrm{His}_{6}$ affinitás-peptiddel ellátott élesztő cyc3 gént tartalmazó pCS315 plazmidot kaptunk ajándékba Dr. Carsten Sanderstől (Kutztown, University of Pennsylvania, Sanders 2000).

Klónozáshoz XL1-Blue MRF', fehérje-túltermeléshez BL21-AI (Invitrogen) és EC06 (Thony-Meyer 1995) E. coli törzseket használtunk. Kompetenssejt-készítés és a 
törzsek transzformálása során az Inoue és mtsi. (1990) által leírt eljárást követtük.

\section{Citokróm $c$ mutagenezis}

A citokróm $c$ cisztein mutánsainak előállítása kétlépéses PCR-amplifikációval történt (Ho 1989, Ausubel 1996). Az amplifikációhoz 3'-5' proofreading exonukleáz aktivitással bíró Pfu DNS-polimeráz enzimet (Fermentas) használtunk. Az első lépésben két kisebb, de átfedő és a mutációt tartalmazó fragmentum képződött, amelyeket a következő PCR-lépésben a teljes gént tartalmazó fragmentummá amplifikáltunk. Az mutáns gént tartalmazó fragmentum két végére tervezett restrikciós endonukleáz hasítóhelyekkel a gént a megfelelö orientációban T4 DNS-ligázzal a pBAD24HCyc1-Cyc3NcoI- kazettájába lehetett ligálni. A K8C-as mutáns előállításához tervezett előreirányuló és visszairányuló mutagenezis primerek szekvenciái a következök voltak: 5'-GGTAAGTGCATTTTCGTTC3', és 5'-GAACGAAAATGCACTTACC-3'. A K39C mutáns esetében pedig az előremutatónak a szekvenciája: 5'-CGGTCGTTGCACCGGTCAA-3', a visszairányuló szekvenciája: 5'-TTGACCGGTGCAACGACCG-3' volt. A PCR mutagenezishez használt külső primerek az 5'-ACACAGGAACTCGACCATGG-3' és az 5' AGCTTGGCCGGATCCCATAA-3' voltak. A irányított mutagenezissel előállított mutáns citokróm $c$ géneket szekvenáltattuk és meggyőződtünk arról, hogy az amplifikáció során csakis a kívánt szakaszon történt nukleotidcsere.

\section{Fehérje-túltermelési procedúrák}

A citokróm $c$ expressziójára két különböző expressziós rendszer is szolgált. A két rendszer kissé különböző inkubációs és indukciós körülményt igényelt. Terveztünk egy kétkomponensü expressziós rendszert, amelyben a citokróm $c$ és a CCHL génje tandem módon, egy plazmidon, egy promóter szabályozása alatt állt. A másik expressziós rendszer egy-komponensü volt, amikor is a citokróm $c$ és a CCHL génjei különböző plazmidokról íródtak át, különböző promóterek szabályozása alatt álló expressziót téve lehetővé. Ez esetben értelemszerüen a plazmidok szelekciós markerei más - más antibiotikumrezisztencia génnel, a szabályozás pedig a két promóternek köszönhetően más és más induktoranyaggal oldható meg.

A fent leírt konstrukciók ismeretében a későbbiekben az alternatívák utalnak arra, hogy az expresszió milyen körülmények között történt. Az itt leírt túltermelő és tisztítási procedúra érvényes a nem-enzimatikusan érő citokróm $c$ kísérletekre is. 


\section{Fehérjetisztítási procedúrák}

Citokróm c túltermelésének és tisztításának módszere

A $35{ }^{\circ} \mathrm{C}$-on OVN (overnight) inkubált indítókultúrát százszoros hígításban oltottuk át a megfelelő koncentrációjú antibiotikumot (30 $\mu \mathrm{g} / \mathrm{ml}$ kloramfenikolt és/vagy $100 \mu \mathrm{g} / \mathrm{ml}$ ampicillint), $1 \%$ glicerint tartalmazó, SB (Superbroth) tápoldatra, amelyet intenzív kevertetés mellett inkubáltunk, amíg a kultúra logaritmikus növekedési fázisa elérte a 0,7 $0,8 \mathrm{OD}_{600}$-at. Ezen a ponton indukáltuk a fehérjetermelést $1 \mathrm{mM}$ IPTG-vel (isopropyl-betaD-thiogalactopyranoside) és/vagy 0,5\% arabinózzal, mert ez a sejtsürüség ideális arra, hogy a kultúra a lehető legnagyobb fehérjehozamot adja. A megadott hőmérsékleten intenzív rázogatással 16 órán keresztül inkubáltuk a kultúrát, majd 10 perc 10.000 x g centrifugálással, $4{ }^{0} \mathrm{C}$-on leülepítettük a sejteket és $-70{ }^{0} \mathrm{C}$-on tároltuk a sejtpasztát a felhasználásig.

A feldolgozás első lépéseként a sejtpasztából $100 \mu \mathrm{g} / \mathrm{ml}$ lizozimmal, 2,5 U/ml benzonázzal kiegészített $50 \mathrm{mM}$ Na-foszfát pufferrel $(\mathrm{pH}=7,00)$ sejtextraktumot készítettünk. Jégen és szobahőmérsékleten való 30 perces inkubálás után a sejtpasztát szonikálásnak vetettük alá (2 ciklus 40”, MSE szonikátor, $15 \mu \mathrm{m}$ amplitúdó). Az extraktum citokróm $c$-t tartalmazó szolubilis részét az üledéktől $4{ }^{0} \mathrm{C}$-on egy óra 100.000 x g ultracentrifugálással választottuk el. Ezt a szolubilis fehérjéket tartalmazó felülúszót első lépésben 50\%-os telítettségü ammónium szulfát kisózásnak vetettük alá. Az így kisózott fehérjéket $4{ }^{0} \mathrm{C}$-on 10 perces 16.000 x g centrifugálással kiülepítettük az oldatból, majd Amicon töményítővel és dialízissel a puffert $50 \mathrm{mM}$ Na-foszfát pufferre $(\mathrm{pH}=7,00)$ cseréltük. Az így kapott fehérjeoldatból FPLC készüléken (Pharmacia) ioncserélő kromatográfiás lépéssel a holocitokróm $c$-t kitisztítottuk. A fehérjeoldatot 7,00 pH-n CM Sephadex C50-es kationcserélö töltetre kötöttük fel, majd a $\mathrm{NaCl}$ koncentrációjának fokozatos növelésével több, mint $90 \%$-os tisztaságú citokróm $c$ oldatot nyertünk. A Strep II peptiddel jelölt citokrómokat affinitás-kromatográfiával Strep-Tactin Sepharose (IBA) tölteten a kézikönyvben leírt tisztítási procedúrát követve továbbtisztítottuk.

\section{CCHL túltermelésének és tisztításának módszere}

Az élesztő CCHL túltermelése és tisztításának első fázisa néhány részletben eltért a citokrómétól. A $35{ }^{0} \mathrm{C}$-on OVN inkubált indítókultúrát százszoros hígításban oltottuk át a megfelelő koncentrációjú antibiotikumot, $30 \mu \mathrm{g} / \mathrm{ml}$ kloramfenikolt tartalmazó, SB tápoldatra. A kultúrát intenzív kevertetés mellett inkubáltuk, amíg a sejtek logaritmikus növekedési fázisa el nem érte a 0,7 - 0,8 OD $_{600}$-at. Ezen a ponton indukáltuk a 
fehérjetermelést $1 \mathrm{mM}$ IPTG hozzáadásával. A kultúrát az indukciótól számítva $30{ }^{\circ} \mathrm{C}$-on 3 órán keresztül inkubáltuk, majd a sejteket 10 perc 10.000 x g centrifugálással, $4{ }^{0} \mathrm{C}$-on leülepítettük és $-70{ }^{0} \mathrm{C}$-on tároltuk a sejtpasztát feldolgozásig. A sejtfeltárási procedúra elve ugyanaz, de más kémhatású pufferrel dolgoztunk, illetve a feltárópuffer tartalmazott $1 \mathrm{mM}$ AEBSF (4-(2-Aminoethyl)-benzenesulfonyl fluoride hydrochloride) és $5 \mu \mathrm{M}$ leupeptin proteázinhibitort. A CCHL tisztítása más procedúrát igényel, a fehérje tartalmaz egy $\mathrm{N}$ terminális 6 hisztidinből álló peptidet, ezért a fehérje affinitás-kromatográfiával tisztítható fémkeláló Sepharose tölteten (GE Healthcare). A His 6 peptiden alapuló tisztítási procedúra főbb lépései az Ausubel (1996) protokoll könyvben leírtaknak felelnek meg. A sejt szolubilis extraktumával dolgoztunk, amelyet FPLC (Pharmacia) készülék segítségével kötöttük a nikkelt keláló Sepharose töltetre. A CCHL tiszta frakcióját 300 mM imidazolkoncentrációnál eluáltuk, 0,5 M NaCl-ot tartalmazó $50 \mathrm{mM}$ Na-foszfát pufferben $(\mathrm{pH}=7,50)$.

\section{Fehérje tisztaságvizsgálati és analitikai módszerek}

A fehérjeoldatokat SDS (sodium dodecyl sulfate) poliakrilamid gélelektroforézissel (PAGE) megvizsgáltuk tisztaság szempontjából. $15 \%$-os poliakrilamid gélen szeparáltuk, majd Coomassie BB G-250 festékkel tettük láthatóvá a fehérjéket.

\section{Abszorpciós és cirkuláris dikroizmus (CD) spektroszkópiai mérések}

A fehérjék tisztaságának megállapítására, továbbá az enzimatikusan vagy spontán képződött holocitokrómok szerkezeti összehasonlítására a fehérjeoldatok UV és látható tartományú abszorpciós spektrumát Unicam UV4 spektrofotométeren megmértük.

Másodlagos szerkezeti elemzések céljából ultraibolya tartományban cirkuláris dikroizmus méréseket végeztünk Jasco J-815 spektropolariméteren. A spektrumokat 0,2 mm optikai úthosszú kvarcküvettában, $10 \mu \mathrm{M}$ fehérjekoncentráció mellett mértük. Ezeket a méréseket kiegészítendő a távolabbi UV tartományt is magába foglaló CD spektrumokat mértünk Dániában, az Aarhusban müködő ISA szinkrotron központ CD1 sugárnyalábjában, ugyancsak $10 \mu \mathrm{M}$ fehérjekoncentráció mellett, 0,1 mm úthosszon.

\section{Hem peroxidáz-aktivitási mérések gélben}

Az SDS poliakrilamid gélben mért hem peroxidáz-aktivitáshoz a mintákat gélre

vivés előtt speciálisan kell kezelni. A mintát nem kell fözni, csak $43{ }^{0} \mathrm{C}$-on 15 percig inkubálni a következő kétszeresére hígított felvivőpufferben: 120 mM Tris, pH=7,50, 20 \% 
glicerin, 4,6 \% SDS, amely nem tartalmaz merkaptoetanolt (Vargas 1993). Aktivitásméréshez a gél pufferét lecseréltük 115 mM NaCl-ot tartalmazó $20 \mathrm{mM} \mathrm{K}$, Nafoszfát pufferre, $\mathrm{pH}=7,50$.

A hem peroxidáz-aktivitásának a mérésére előhívó elegyet készítettünk, amelyhez 50 - $50 \%$ arányban kevertük a SuperSignal® West Pico Chemiluminescent Substrate (Pierce) kit két komponensét (luminol és hidrogén peroxid) és egy VersaDoc Imaging System készülékkel detektáltuk az így keletkező kemilumineszcenciás jelet.

\section{A peptidfúziós fehérjék azonosítása immunodetekcióval}

A Strep II vagy His 6 peptiddel ellátott fehérjéket gélen történő elválasztásuk után nitrocellulóz membránra $(0,45 \mu \mathrm{m}$ pórusméret) vittük át Western blot analízis céljából. A tormaperoxidáz-konjugált antitestek (StrepMAB-Classic HRP, egérből és His 6 antibody HRP, nyúlból, IBA) peroxidáz-aktivitásának mérése a fent említett hem peroxidáz-aktivitás mérésekhez hasonlóan történt. A kemilumineszcenciás jelet egy VersaDoc Imaging System készülékkel vagy röntgenfilmen autoradiográfiás módszerrel detektáltuk.

\section{Piridin hemokróm spektrális mérések}

A piridin hemokróm kísérlet Bartsch (1971) protokolljának megfelelöen történt. A Na-ditionittal redukált $10 \mu \mathrm{M}$ nem-enizmatikusan érö citokróm $c$ piridin ferrohemokróm abszorpciós spektrumát $30 \%$ piridin és $200 \mathrm{mM} \mathrm{NaOH}$ elegyében mértük. Hasonló kísérletben referenciaspektrumnak megmértük a ló szív citokróm c (Sigma-Aldrich, C7752 ) és az enzimatikusan érő citokróm $c$ piridin hemokróm spektrumait.

\section{Redoxpotenciál mérések}

A citokróm c redukciós potenciáljának meghatározására kémiai módszert alkalmaztunk. A redukciós potenciál spektrofotometriás méréséhez Na-ferricianiddal titráltunk (Craig 2006) $1 \mathrm{ml}$ térfogatnyi $50 \mathrm{mM}$ Na-foszfát pufferben $(\mathrm{pH}=7,00), 10 \mu \mathrm{M}$ redukált citokróm $c$-t. A fehérjét $10 \mathrm{mM}$ ferrocianiddal redukáltuk, majd 5 - $10 \mu 11 \mathrm{mM}$ ferricianid oldattal fokozatosan oxidáltuk. Ismerve a ferri-/ferrocianid középponti redoxpoteciálját standard hidrogén elektródához (SHE) viszonyítva és a két forma arányát minden egyes lépésben, a Nernst egyenletből kiszámoltuk az oldat aktuális redoxpotenciálját. A 475 - 600 nm hullámhossz-tartományban felvett keverékspektrumokból nemlineáris legkisebb négyzetes illesztéssel kiszámoltuk a redukált/oxidált citokróm $c$ arányt, és ismerve az oldat ferri- és ferrocianid által beállított redoxpotenciálját a Nernst 
egyenletet újra alkalmazva kiszámoltuk a citokróm $c$ SHE-hez viszonyított középponti redukciós potenciálját.

\section{Citokróm $c$ oxidáz (COX) aktivitási kísérletek}

A citokróm $c$ oxidázt marha szívizomból preparáltuk King és Yonetani (1967) módszere alapján. Az aktivitásméréseket Model 10 (Rank Brothers Ltd) oxigráfon végeztük, $500 \mu$ mintatérfogatban. A reakcióelegy $20 \mu \mathrm{M}$ TMPD-t (NNNN-tetramethyl-pphenylenediamine), $10 \mathrm{mM}$ aszkorbátot, 0,05\% dodecilmaltozidot és $100 \mathrm{nM}$ COX-ot is tartalmazott $50 \mathrm{mM}$ Na-foszfát pufferben, pH=7,00. Ehhez az elegyhez adtunk különböző térfogatú autentikus, enzimatikusan érő, illetve nem-enzimatikusan érő ló citokróm $c$ törzsoldatokat, és mértük az oldott molekuláris oxigén koncentrációjának csökkenését. Meghatároztuk az oxigénfogyás kezdeti sebességét a szubsztrát (redukált citokróm $c$ ) koncentrációjának függvényében, majd legkisebb négyzetes illesztéssel a COX-citokróm $c$ enzimreakció kinetikus paramétereit is, azaz a Michaelis-Menten konstanst $\left(\mathrm{K}_{\mathrm{m}}\right)$ és a $\mathrm{V}_{\max ^{-}}$ ot. Utóbbit a szakirodalomban szokásos mértékegységben, $\left(\mu \mathrm{mol} \mathrm{O}_{2}\right) / \mathrm{perc} /(\mathrm{mg} \mathrm{COX})$-ban fejeztük ki. Az oxigénfogyás sebessége a szubsztrát fogyási sebességének egynegyede, mivel 4 citokróm $c$ molekula által szállított 1-1 elektron redukál egy oxigénmolekulát.

\section{Autoxidációs mérések}

A kísérlethez a különböző módokon érő (nem-enzimatikusan, enzimatikusan érő és ló szívizomból származó) citokróm $c$ fehérjéket $2 \mu \mathrm{M}$-os koncentrációban $3 \mathrm{mM}$ ditiotreitollal (DTT) teljesen redukáltuk, majd a DTT-t dialízissel eltávolítottuk és szobahőmérsékleten, $25 \mathrm{mM}$ Na-foszfát pufferrel $(\mathrm{pH}=7,00)$ szemben napokig dializáltuk. A fehérjék oxidációját abszorpciós spektrumok mérésével követtük nyomon.

\section{Hem törzsoldat készítése}

$\mathrm{Az}$ in vitro kísérletekhez $10 \mathrm{mM}$ hemin, $100 \mathrm{mM} \mathrm{NaOH}$ vizes törzsoldatot készítettünk. A törzsoldatot tízszeresére hígítottuk oxigénmentes, $100 \mathrm{mM} \mathrm{NaOH}$-ot tartalmazó HEPES vagy Na-foszfát pufferben.

\section{Apocitokróm $c$ készítés}

A módszer, amellyel a hemet eltávolítottuk Ambler és mtsi. (1973) által leírt protokollon alapszik.

A hem eltávolításához a ló szívizom citokróm $c$-t (Sigma) 100 mM HCl-ot és $8 \mathrm{M}$ 
ureát tartalmazó oldatban denaturáltuk, amelyhez kétszeres mennyiségü $\mathrm{HgCl}_{2}$-ot adtunk. Az oldatot 20 órán keresztül $37{ }^{0} \mathrm{C}$-on inkubáltuk, rázogatás mellett. Sephadex G-25 gélszürő tölteten a szabad hemet és az apocitokrómot szétválasztottuk, majd 20 x-os mennyiségü ditiotreitollal $50{ }^{0} \mathrm{C}$-on, 20 percig kezeltük a mintát, így a $\mathrm{CXXCH}$ motívum cisztein-oldalláncai között kialakult $\mathrm{Hg}$-hidat felszakítottuk. Ezt követően újabb gélszüréssel és dialízissel puffert cseréltünk a mintán (20 mM HEPES vagy 20 mM Nafoszfát pufferekre).

\section{A CCHL és az apocitokróm $c$ oldatok koncentrációjának meghatározása}

A CCHL és az apocitokróm $c$ tiszta fehérjeoldatok koncentrációját a $280 \mathrm{~nm}$-es UV abszorpciós csúcs amplitúdójából számoltuk ki. A fehérjék elsődleges szekvenciája alapján a His ${ }_{6}$ fúziós CCHL $1 \mathrm{mg} / \mathrm{ml}$-es oldatának az extinkciós koefficiense 1,46, az apocitokróm $c$-é pedig 0,93. Ezeket az értékeket vettük figyelembe a mért fehérjeoldatok tömegkoncentrációjának, illetve moláris koncentrációjának kiszámításakor.

\section{In vitro kísérletek}

A CCHL és hem kölcsönhatásának kísérleteit $25{ }^{0} \mathrm{C}$-on végeztük, a kísérlet ideje alatt a küvettát lezártuk és nitrogénre cseréltük a légteret. A CCHL és a hem $1: 1$, illetve 1 : 0,5 arányú keverékét alkalmaztuk, 5 - $10 \mu \mathrm{M}$ koncentráció-tartományban, 20 mM HEPES vagy $20 \mathrm{mM}$ Na-foszfát pufferekben, $\mathrm{pH}=7,50$. A CCHL enzimet keverés előtt ditiotreitollal redukáltuk, majd lezárt edényből redukált hemet adtunk a reakcióelegyhez és abszorpciós spektrumok mérésével követtük a spektrális változásokat.

A CCHL, apocitokróm $c$ és hem in vitro érési kísérleteit $25{ }^{0} \mathrm{C}$-on végeztük. $\mathrm{Az}$ apocitokróm $c$, CCHL és a redukált hem $1: 1: 2$, illetve $1: 0,5: 2$ arányú keverékét alkalmaztuk, 5 - $20 \mu \mathrm{M}$ koncentráció-tartományban, $20 \mathrm{mM}$ HEPES vagy $20 \mathrm{mM} \mathrm{Na}$ foszfát pufferekben, pH=7,50. A puffereket tartalmazó edényeket lezártuk, és felhasználás elött alaposan átbuborékoltattuk nitrogénnel. Az apocitokróm $c$ és a CCHL fehérjék keverékét a hem hozzáadása előtt ditiotreitollal redukáltuk. A reakciót 100 mM kristályos Na-ditionit hozzáadásával indítottuk, a küvettát lezártuk, a légteret nitrogénre cseréltük és a reakció ideje alatt folyamatosan abszorpciós spektrumokat mértünk.

Az in vitro kísérletekből megfelelő időközönként, illetve a reakció végén mintát vettünk, folyékony nitrogénben azonnal lefagyasztottuk és denaturáló gélen megfuttattuk, majd hem kemilumineszcenciás jel detektálásával igazoltuk a hem és az apocitokróm $c$ közötti kovalens kötést. 


\section{Eredmények}

\section{Mutáns $c$ típusú citokrómok termeltetése heterológ expressziós rendszerben}

\section{Citokróm c mutagenezis}

Az irányított mutagenezist kétlépéses PCR-amplifikációval valósítottuk meg olyan oligonukleotidokkal, amelyek az általunk bevinni kívánt mutációt szekvenciájukban hordozták (9. ábra, A).

Az első PCR-lépésben két darab, egymást átfedő és a mutációt tartalmazó DNS fragmentum képződött. A második PCR-lépésben a két fragmentum egymás primerjeiként szolgálva eredményezte a teljes mutáns gént tartalmazó fragmentumot. Ebben a lépésben két külső primert is alkalmazva egy olyan fragmentumot amplifikáltunk, amely a mutáns citokróm $c$ génjét tartalmazta. A fragmentum végeit a kívánt restrikciós endonukleázokkal hasítottuk, és orientáltan a kompatibilis végekkel rendelkező pBAD24 plazmid megfelelő kazettájába ligáltuk. Ennek eredményeképpen kaptuk a pBAD24HCyc1-YCyc3NcoIexpressziós plazmidot (9. ábra, B és C) (Tenger 2007).

\section{Heterológ citokróm c expresszió és fehérjeizoláció}

A gének transzkripcióját arabinóz indukcióval indítottuk a $\mathrm{P}_{\mathrm{BAD}}$ promóterről. Az arabinóz indukálta expresszióhoz az ara ${ }^{-}$BL21-AI törzset használtuk, amely az arabinózt nem képes cukorforrásként felhasználni. Egy másik törzs, az EC06, amely citokróm $c$ maturációban mutáns, mint negatív háttér szerepelt a nem-enzimatikus citokróm $c$ érésben. A pBAD24-es plazmiddal és a BL21-AI törzzsel sikerült egy megbízhatóan müködő és az addig használt rendszerhez viszonyítva legalább háromszoros hozamot biztosító expressziós rendszert kifejleszteni. A magas citokróm $c$ szint a sejtpaszta színét pirosra változtatja, így hozama a sejt szolubilis extraktumának abszorpciós spektrumából meghatározható. Az 1 liter baktérium kultúrára számolt hozam akár $37 \mathrm{mg}$ vad típusú citokróm $c$-t is eredményezhet (Tenger 2007). Ez az érték nagyjából 4 - 5 mg vad típusú citokróm $c 1 \mathrm{~g}$ nedves sejtre vonatkoztatva, de ez a hozam változik mutánsról mutánsra és törzsről törzsre is. Ez a magas hozam elérhető mind a tandem, kétcisztronos (az apocitokróm $c$ és a CCHL génje egy plazmidon), mind külön promóterekről átíródó, kétplazmidos változat esetében.

Az enzimatikusan érő citokróm $c$ tisztításának első lépéseként, ultracentrifugálást követően, a sejt szolubilis frakciójából 50 \%-os ammónium szulfát kisózást alkalmaztunk. A kicsapódott fehérjéket centrifugálással leülepítettük, majd a fehérjeoldat dialízisét és töményítését követően a citokróm $c$ fehérjéket kationcserélő tölteten megtisztítottuk. 
A
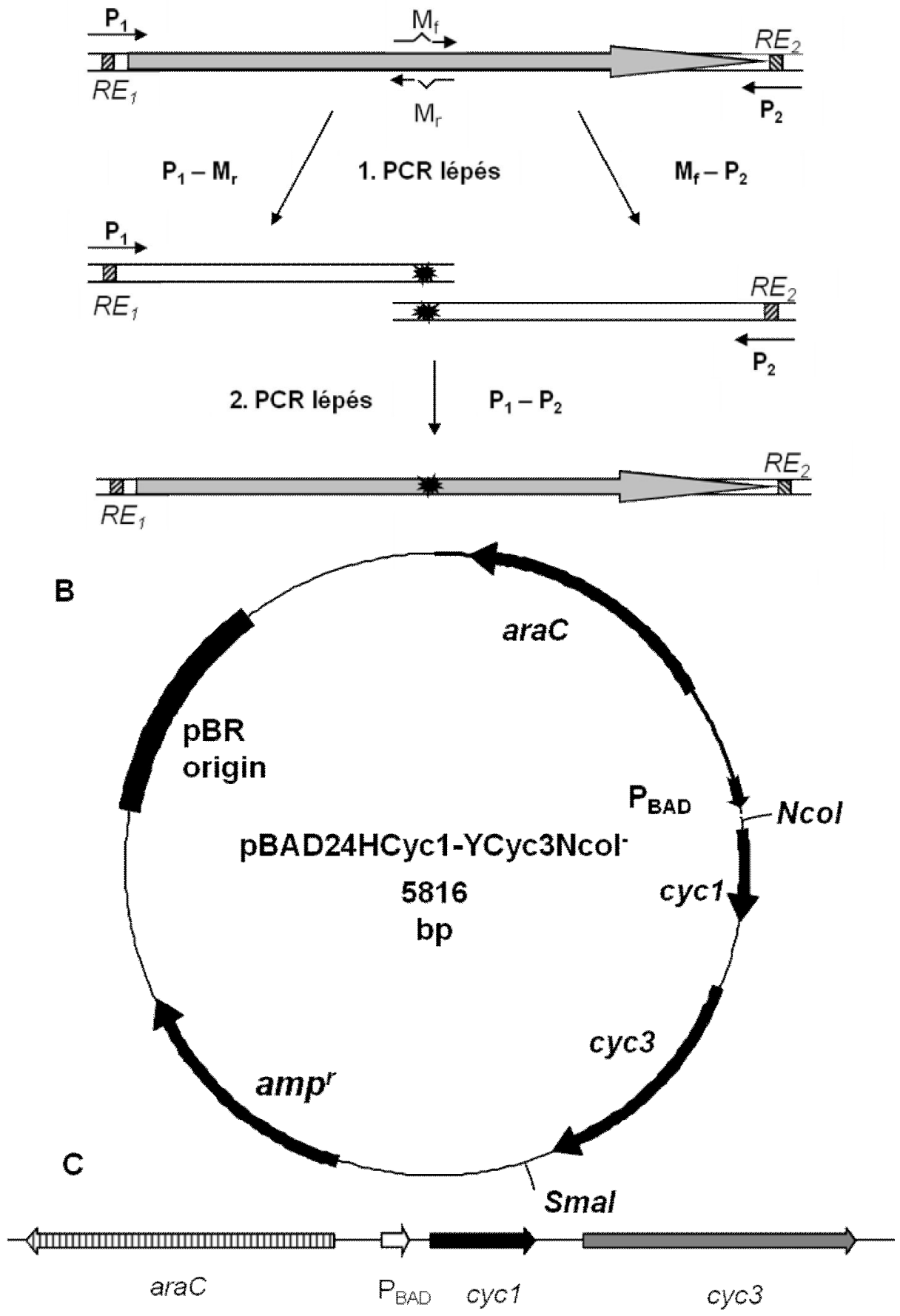

9. ábra. A kétlépéses irányított mutagenezis mechanizmusa és a nagy hozamot biztosító expressziós konstrukció térképe:

A: A kétlépéses irányított mutagenezis stratégiája. $\mathrm{P}_{1}$ : az 5' végi, $\mathrm{P}_{2}$ : a 3' végi külső primerek, $\mathrm{M}_{\mathrm{f}}$ és $\mathrm{M}_{\mathrm{r}}$ : előre- és visszairányuló, a mutációt hordozó primerek, RE: restrikciós endonukleáz hasítóhely.

B: A pBAD24HCyc1-YCyc3 $\mathrm{NcoI}^{-}$expressziós plazmid térképe, citokróm $c$ (cycl) és CCHL (cyc3) génekkel, amp ${ }^{\mathrm{r}}$ : ampicillin rezisztenciát biztosító fehérje génje, bp: bázispár, $\mathrm{P}_{\mathrm{B} A \mathrm{D}}$ : arabinóz indukálható promóter, pBR origin: replikációs origo.

C: Az expressziós plazmid releváns szakasza, araC: az arabinóz-indukálható promóterről az expressziót szabályozó fehérje génje. 
A BL21-AI E. coli törzsben expresszált mutáns és vad típusú citokrómok tisztaságát a 10. ábra mutatja.

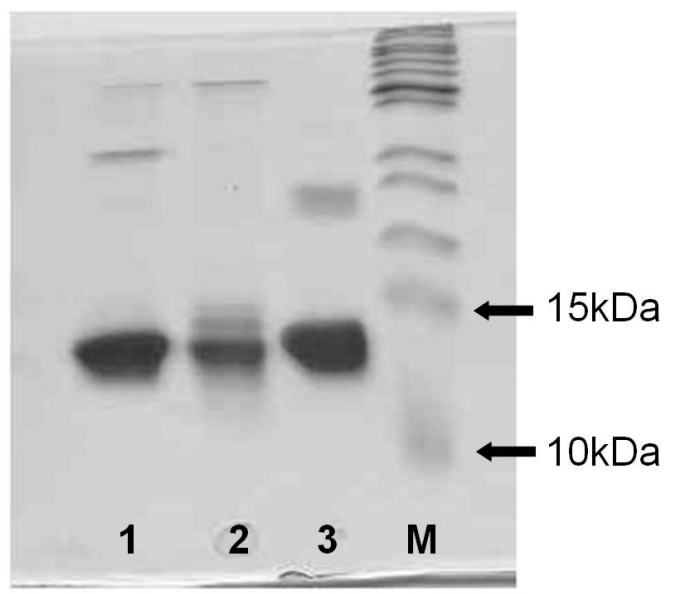

10. ábra. BL21-AI E. coli törzsben expresszált mutáns és vad típusú citokróm $c$-k tisztaságát bemutató $15 \%$-os SDS-poliakrilamid gél. Coomassie BB G-250 festés.

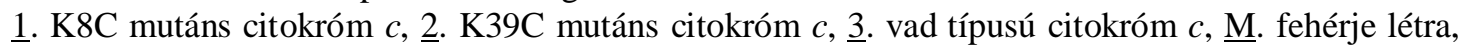
Fermentas SM0671. 3 $\mu \mathrm{g}$ citokróm c/oszlop.

A citokróm $c$ nem-enzimatikus érésének vizsgálatához a tisztítás céljából Strep II peptid-fuzionált cycl gént a pBAD24 plazmidba klónoztuk és a plazmiddal BL21-AI, illetve EC06 E. coli törzseket transzformáltunk (Tenger 2010). A spontán érő citokróm $c$ hozamának meghatározása csak tisztított fehérjéből lehetséges. A hozam összehasonlításához az enzimatikusan érő citokróm $c$ kitermelését tisztítás után, a tisztítási veszteséget beleszámolva határoztuk meg. A kationcserélő kromatográfiás lépés után mért abszorpciós spektrumból számoltuk ki a citokróm c mennyiséget, amely szerint a nemenzimatikusan érő hozama az enzimatikusan érőnek 2\%-a.

A pCS315 plazmidban a CCHL génje IPTG indukálható tac promóter szabályozása alatt áll, és plazmidja kompatibilis a citokróm $c$ pBAD24 plazmidjával. Kotranszformációjuk BL21-AI, illetve EC06 E. coli törzsekbe és expressziójuk lehetővé teszi funkcionális citokróm $c$ bioszintézisét.

\section{Elektrontranszfer kísérletek citokróm $c$ fehérjében és azok értelmezése}

A citokróm $c$ redoxfehérje alkalmas fehérjék elektrontranszfer sebességének és az elektrontranszfer útvonaltól függő hatékonyságának a vizsgálatára. E célból ló citokróm $c$ cisztein mutánsokat terveztünk, azokat irányított mutagenezissel létrehoztuk és hatékonyan expresszáltuk. A mutagenezissel bevitt cisztein-oldalláncokon kovalensen jelöltük a fehérjéket egy arra alkalmas fotoaktív festékkel, TUPS-szal (1-thiouredopyrene-3,6,8trisulfonate). A ló citokróm $c$ szekvenciája a hem kötésében résztvevő két ciszteinen kívül 
nem tartalmaz más ciszteint, ezért szekvencia-módosítással, felületi aminosavak ciszteinre cserélésével, a fehérje a kívánt pozícióban jelölhető. A jelölt mutánsok alkalmasak fehérjén belüli és citokróm $c$ oxidázzal komplexben pedig fehérjék közötti fényindukált elektrontovábbítási folyamatok vizsgálatára. Ezek az elektrontranszfer folyamatok tranziens spektrális változások révén kinetikus abszorpciós spektroszkópiai módszerekkel követhetőek. A fotoaktív donor-molekula pozíciójának változtatásával a donor és az akceptor közötti távolság módosítható, illetve a fehérje különböző tartományai vonhatók be az elektrontranszfer folyamatába. Így vizsgálható a távolságnak az elektrontranszfer sebességére gyakorolt hatása és a fehérjemátrix szerepe a hosszútávú elektrontranszfer folyamatokban.

Az elektrontranszfer mérések egy másik doktori dolgozat tárgyát fogják képezni. Itt csak röviden térek ki az eredmények tárgyalására. Eszerint 13 felszíni aminosavat cseréltünk ki ciszteinre részben mi, részben orosz partnereink, és jelöltük meg a ciszteineket TUPS-szal. A mérési eredményeink érintőleges bemutatására két mutánst választottam ki, ahol olyan lizin-oldalláncokat cseréltünk ki, amelyeket korábban a TUPS lizinhez köthető változatával jelöltünk meg és felhasználtunk elektrontranszfer kísérletekben. Így, ebben a két esetben, közvetlenül összehasonlítható volt az ugyanabban a pozícióban lévő, de egyszer lizinhez, máskor meg ciszteinhez kötött TUPS és a fehérje hemcsoportja közötti elektrontranszfer. A két eset közötti jellemző különbség az, hogy a lizines változat egy kovalens kötéssel rövidebb a ciszteines változatnál (11. ábra).
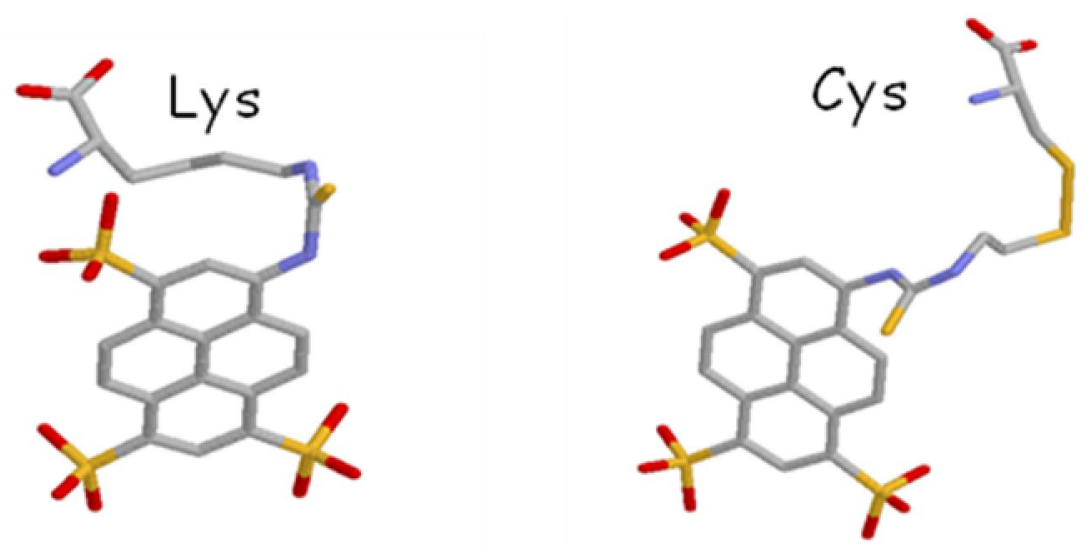

11. ábra. A TUPS jelölő két változata.

Ennek ellenére a lizinhez kötött TUPS és a hem közötti elektrontranszfer sebessége nem adódott nagyobbnak, ahogy pedig elvárható lenne, ha az elektrontranszfer követné a kovalens útvonalat. Másik jellemző megfigyelésünk az volt, hogy az esetek többségében a 
különböző helyekre kötött TUPS és a hem közötti elektrontranszfer több időbeli exponenciális összegével illeszthető csak. Harmadik megfigyelésünk szerint pedig csak laza korreláció tapasztalható a különböző helyeken lévő TUPS és a hem közötti elektrontranszfer sebessége és a kettő geometriai távolsága, avagy a kettő közötti kovalens útvonal hossza között. A fenti kísérleti eredmények egy olyan modellel voltak magyarázhatóak, amely szerint a TUPS flexibilis „,nyele” révén több, az elektrontranszfer időskáláján stabilnak tekinthető helyzetet foglalhat el a fehérje felszínén, és a TUPS gyürüs szerkezetéről a hem felé az optimális útvonal sok esetben térbeli ugrással kezdődik a fehérje valamely felszíni atomjára (Tenger 2005). A molekuláris dinamikai számításokkal alátámasztott TUPShelyzetektől a hemhez számolt optimális elektrontranszfer-útvonalak, melyek az esetek többségében a kovalens kötéseken kívül térbeli ugrásokat is tartalmaztak, illetve az ezekből számolt elektrontranszfer-sebességek már jobb korrelációt mutattak a mérésekből meghatározott sebességekkel. Az elektrontranszfer számolásokat a szabadon felhasználható HARLEM programmal végeztük (www.kurnikov.org).

\section{Emlős citokróm $c$ nem-enzimatikus érése baktériumban}

A citokróm c nem-enzimatikus érésének bizonyitékai: a fehérje detektálása

A Strep II peptiddel fuzionáltatott citokróm $c$ expresszióját SDS denaturáló gélelektroforézist követően Western blot immunodetekcióval demonstráltuk. Az expressziót követően a teljes sejtextraktumot szeparáltuk $15 \%$-os SDS poliakrilamid gélen (12. ábra, A, B és C, 1 oszlopok). Alacsony hozama miatt a citokróm $c$ nem-enzimatikus érését kationcserélő és affinitás-kromatográfiás tisztítás után demonstrálhattuk (12. ábra, A, 2 oszlop).

Annak ellenére, hogy Strep II peptid-antitest segítségével azonosítottuk a fehérjénket és bizonyítottuk, hogy az általunk túltermeltetett fehérjéről van szó, kontroll kísérleteket is végeztünk. A génmentes plazmidot tartalmazó BL21-AI törzset ugyanolyan expresssziós körülményeknek vetettük alá, mint amilyent a gént tartalmazó esetben is alkalmaztunk. Sejtextraktumát denaturáló gélben megfutattuk és blottolást követően immunológiai analízist végeztünk. Hasonlóan negatív eredményt hozott az a kísérlet is, amelyben a géneket ugyan hordozta a plazmid, de a fehérje-expressziót nem indukáltuk. A kontroll kísérletek negatív eredményei megerősítették konklúziónkat, miszerint az expresszált, immunológiailag detektált és tisztított citokróm $c$ az általunk bevitt gén terméke. 
A citokróm c nem-enzimatikus érésének bizonyitékai: a hem kimutatása a fehérjében

Denaturáló gélelektroforézist követően a kovalensen kötött hem luminol és hidrogén-peroxid szubsztrátok jelenlétében peroxidáz-aktivitást mutat. Az így keletkező kemilumineszcenciás jel detektálásával igazoltuk a hem kovalens beépülését a nemenzimatikusan érő citokróm $c$ fehérjébe (12. ábra, B, 2 oszlop). A Western blot analízis, amellyel a fehérjét azonosítottuk, a tisztított fehérje magasságában intenzív dupla csíkot adott, a hem peroxidáz-aktivitás pedig egyszereset. Az alacsonyabb molekulatömegú csík az apocitokróm $c$ Strep II peptidjétől származhat. Az apocitokróm $c$ valószínüleg olyan, a hemjét kovalensen nem kötő vagy nem natívan kötő fehérjékből származik, amelyeket a tisztítási procedúra során a kromatográfiás lépésekkel nem tudtunk elválasztani és időközben hemjüket veszítették. Ez a populáció viszont a hem hiánya miatt figyelmen kívül hagyható a holofehérje - később ismertetett - fizikai-kémiai paramétereinek, mint abszorpciós spektrum, piridin hemokróm spektrum, COX aktivitás, redukciós potenciál, mérésekor.

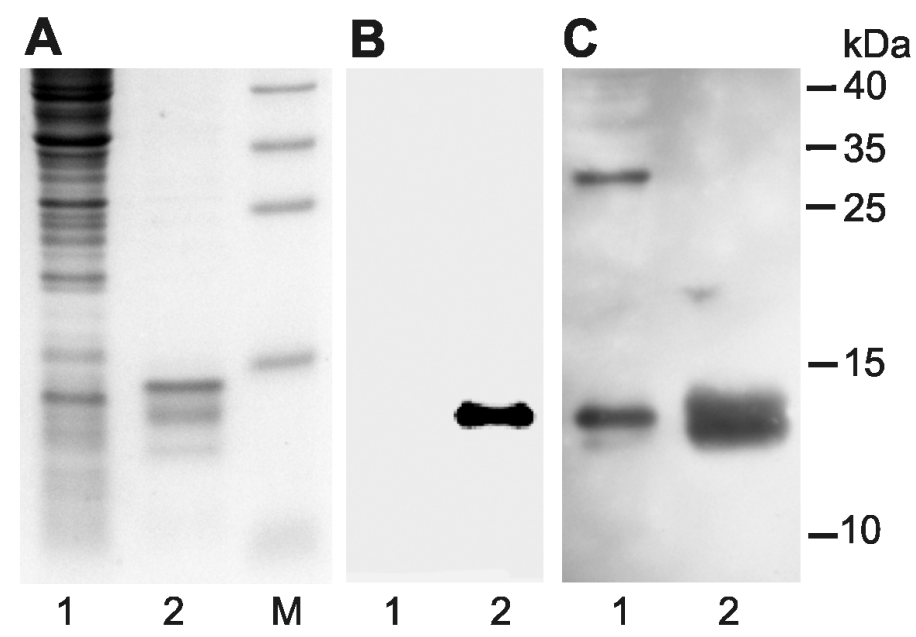

12. ábra. A nem-enzimatikusan érő citokróm $c$ kimutatása denaturáló gélben, a BL21-AI E. coli törzsből származó mintákon.

A: $15 \%$-os SDS poliakrilamid gél, Coomassie BB G-250 festés.

B: SDS gélben felvett kemilumineszcenciás jel, amely a holocitokróm $c$ hem peroxidázaktivitásának következtében keletkezett.

C: Strep II peptiddel fuzionált holocitokróm $c$ immunodetektálása StrepMAB-Classic torma peroxidázzal konjugált antitesttel. A kemilumineszcenciás jel autoradiográfiás módszerrel röntgenfilmre van rögzítve.

1. teljes sejtextraktum. $2.80 \mathrm{pmol}(\sim 1 \mu \mathrm{g})$ tisztított nem-enzimatikusan érő citokróm $c$.

M. fehérje létra, Fermentas SM0671.

A citokróm c nem-enzimatikus érésének bizonyitékai: kontroll kísérlet Ccm mutáns törzsben

A nem-enzimatikus érés kontrolljaként alkalmaztunk egy citokróm $c$ maturációban mutáns (EC06) E. coli törzset. Összehasonlítva a nem-enzimatikusan érő citokróm $c$ 
hozamát és abszorpciós spektrumát a két expressziós gazda esetében (EC06 és BL21-AI E. coli törzsek) ugyanazt az eredményt kaptuk: a ccm-mutáns törzsben is termelödött holocitokróm $c$, ami annak közvetlen bizonyítéka, hogy nem a baktérium saját érlelő rendszere katalizálja a citokróm érését.

A citokróm c nem-enzimatikus érésének bizonyítékai: az apocitokróm c expressziójának kinetikája

Az apocitokróm $c$ expressziójának a kinetikáját is meghatároztuk. A BL21-AI expressziós törzsben az arabinóz indukálószer elvileg állandó szintje mellett az apociokróm $c$ felhalmozódását követtük nyomon, párhúzamosan megfigyelve a hasonló módon inkubált, de indukálatlan kultúrákat is. Az expresszió mértéke azonos három órás indukciós időtől kezdve egészen OVN inkubációig, ami az alábbi, SDS-gélanalízist és immunológiai vizsgálatokat szemléltető 13. ábráról derül ki.

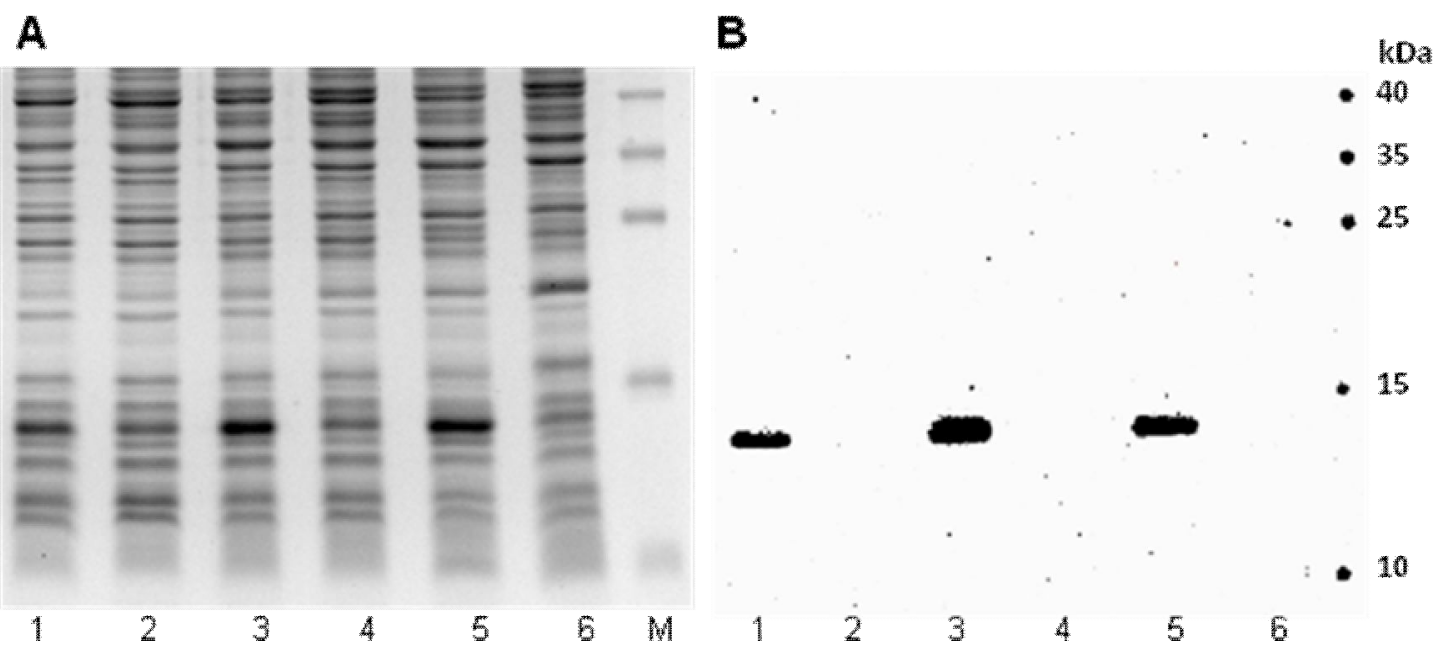

13. ábra. Az apocitokróm $c$ expressziójának kinetikáját bemutató SDS poliakrilamid gél és az apocitokróm $c$ Western blot analízise. E. coli BL21-AI törzsben indukált és indukálatlan kultúrák összehasonlítása. Teljes sejtextraktumokat futtattunk.

A: $15 \%$-os SDS poliakrilamid gél, Coomassie BB G-250 festés.

B: Strep II peptiddel fuzionált citokróm $c$ immunodetektálása nitrocellulóz membránon StrepMABClassic torma peroxidázzal konjugált antitesttel.

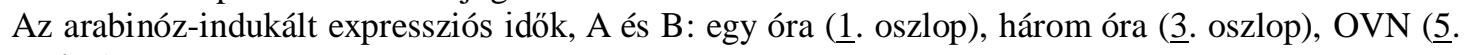
oszlop).

Az indukálatlan kultúrák inkubációs ideje, A és B: egy óra (2․ oszlop), három óra (ㄸ. oszlop), OVN (ㅁ. oszlop). M. fehérje létra, Fermentas SM0671.

A citokróm c nem-enzimatikus érésének bizonyítékai: az apocitokróm c sorsa az E. coli citoplazmájában

Oldatban az apocitokróm $c$ rendezetlen, másodlagos szerkezet nélküli konformációval rendelkezik (Stellwagen 1972, Fisher 1973), ezért túltermelés során a baktériumok citoplazmatikus proteázainak ki van téve mindaddig, amíg hemet nem köt és el 
nem éri natív szerkezetét.

Az apocitokróm c CCHL nélküli expressziójának és lebomlásnak időfüggését vizsgáltuk meg E. coli BL21-AI törzsében (14. ábra). Vizsgálatunk célja az apocitokróm $c$ stabilitásának megállapítása volt. A kísérlet a fehérje-expresszió kloramfenikolos gátlásán alapult. Indukciót követően a fehérje-expressziót egyáltalán nem gátoltuk, vagy egy és három óra után gátoltuk $170 \mu \mathrm{g} / \mathrm{ml}$ kloramfenikollal. A gátolt kultúrákból azonnal mintát vettünk (14. ábra, A és B, 2 és 4 oszlopok), amelyeket $-70{ }^{0} \mathrm{C}$-ra fagyasztottunk, illetve OVN, azaz 16 órán keresztül inkubáltuk azokat a nem gátolt kultúrával együtt (14. ábra, A és B, 1, 3 és 5 oszlopok). OVN inkubáció után ezeket lecentrifugáltuk, $-70{ }^{0} \mathrm{C}$-ra fagyasztottuk későbbi SDS-poliakrilamid gél analízis és immunológiai vizsgálatok céljából.
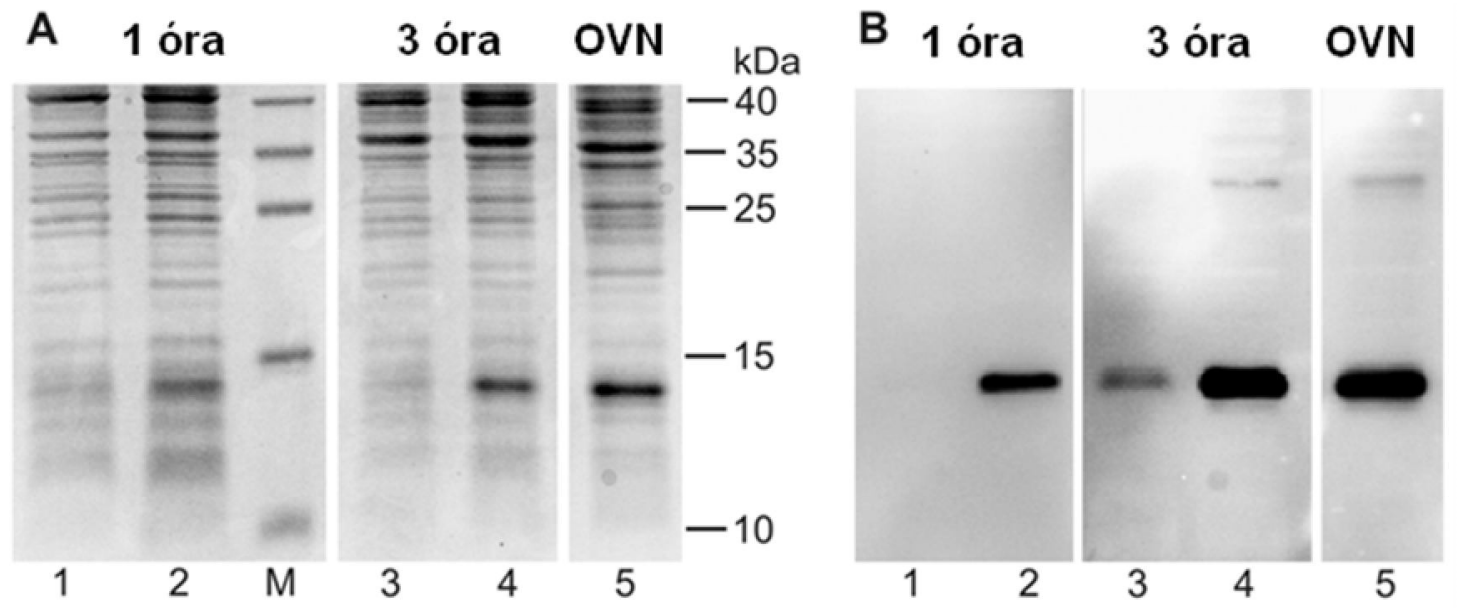

14. ábra. Az apocitokróm $c$ lebomlásának időfüggését bemutató SDS poliakrilamid gél és Western blot analízis. Az apocitokrómot CCHL hiányában az E. coli BL21-AI törzsében expresszáltuk. A kísérletben teljes sejtextraktumokat vizsgáltunk:

A: $15 \%$-os SDS poliakrilamid gél, Coomassie BB G-250 festés.

B: Strep II peptiddel fuzionált apocitokróm $c$ immunodetektálása nitrocellulóz membránon StrepMAB-Classic torma peroxidázzal konjugált antitesttel.

Arabinóz-indukált nem gátolt apocitokróm $c$ expressziója, A és B: egy óra ( 2 oszlop), három óra ( $\underline{4}$ oszlop) és OVN ( $\underline{5}$ oszlop) időszakok alatt.

Az indukciót követő kloramfenikolos gátlás, A és B: egy és három óra után, amely kultúrákat OVN inkubáltuk (1 és $\underline{3}$ oszlopok). $\underline{\text { M: }}$ : fehérje létra, Fermentas SM0671.

A transzláció gátlása után OVN inkubált minták vizsgálatából tudjuk, hogy az apocitokróm $c$ mennyisége az érés hiányában degradáció miatt lényegesen lecsökken. A három órás indukciós időt követő gátlás esetében az OVN mintában még detektálható, de az egy óra alatt felhalmozódott apocitokróm $c$ teljesen lebomlik. Figyelembe véve az apocitokróm $c$ random-coli szerkezetét az mondható, hogy az apofehérje elég stabilnak tekinthető ahhoz, hogy egy OVN periódus alatt enzimatikus asszisztencia nélkül is képes legyen érni. Az érés hozama alacsony, 2\%-a az általunk elért enzimatikusénak, ezért az 
érés tényéről csak a tisztítás után szerezhetünk tudomást és számolhatunk hozamot.

A citokróm c nem-enzimatikus érésének bizonyítékai: spektroszkópiai vizsgálatok

A nem-enzimatikusan érő citokróm $c$ abszorpciós spektrumát összehasonlítottuk az autentikus (ló szívizomból származó) és az enzimatikusan érő citokróm $c$ spektrumával is és azt vettuik észre, hogy a Soret csúcs két, az $\alpha$ csúcs egy nanométeres (1. táblázat) vöröseltolódást mutatott következetesen minden preparáció esetében (15. ábra). Ez a spektrális eltolódás árulkodó lehet a hem környezetével kapcsolatban.

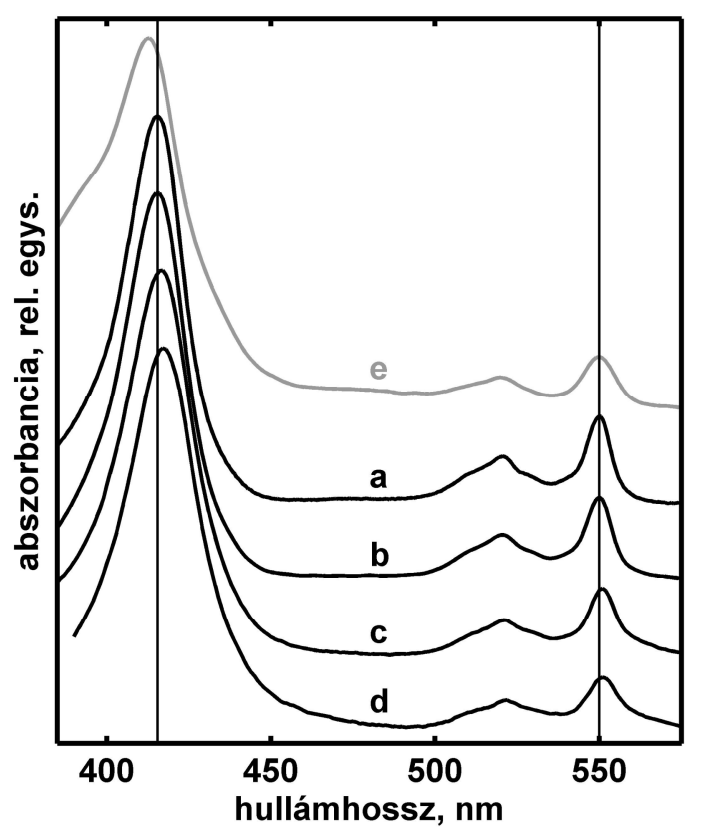

15. ábra. Közeli UV és látható hullámhossz-tartományokban felvett holocitokróm $c$ spektrumok:

a: Autentikus, ló szívizom citokróm $c$.

b: BL21-AI E. coli törzsből tisztított enzimatikusan érő citokróm $c$.

c: BL21-AI E. coli törzsből tisztított nem-enzimatikusan érő citokróm $c$.

d: EC06 E. coli törzsböl tisztított nem-enzimatikusan érö citokróm $c$.

e: A nem-enzimatikusan érő citokróm $c$ piridin hemokróm spektruma.

A spektrumok a Soret csúcs maximumára vannak normálva.

Ahhoz, hogy a hem kötésére vonatkozóan ismereteket nyerhessünk, megvizsgáltuk a nem-enzimatikusan érő citokróm $c$ piridin-koordinált hemokróm spektrumát (15. ábra, e). Denaturáló körülmények között a nem-kötött, az egyszeresen kötött vagy két tioéter kötésen keresztül kötött redukált hemnek jellegzetes piridin-koordinált spektruma van. A nemenzimatikusan érő fehérje piridin hemokróm spektrumának $\alpha$ eltolódása megszünt, a csúcs az autentikus fehérjére és az enzimatikusan érő fehérjére jellemző 550 nm-es értéket mutatott, amely a hem natívval azonos kovalens kötésére utal. 
A nem-enzimatikusan érő citokróm c funkcionalitásának vizsgálata: középponti redoxpotenciál

A nem-enzimatikusan érő citokróm $c$ középponti redoxpotenciálját összehasonlítottuk az autentikus, a CCHL enzimmel érlelt Strep II peptidet tartalmazó, illetve nem-tartalmazó citokróm $c$ változattal is. A nem-enzimatikus citokróm $c$ valamivel alacsonyabb, $243 \pm 4 \mathrm{mV}$ redukciós potenciált mutatott az enzimatikus $260 \pm 5 \mathrm{mV}$ értékéhez képest (pH=7,00, SHE-hez viszonyítva) (16. ábra és 1. táblázat).

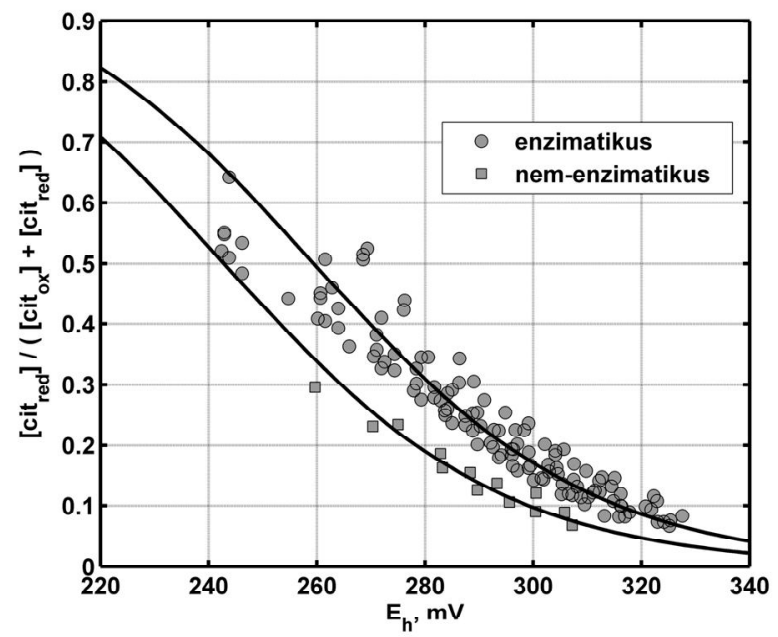

16. ábra. A redukált citokróm $c$ részaránya az oldat redoxpotenciáljának függvényében, enzimatikusan érlelt citokróm $c$ (kör), illetve nem-enzimatikusan érő citokróm $c$ (négyzet) esetén. A folytonos vonal a Nernst-egyenlet legkisebb négyzetes illesztése a mérési értékekre.

Tekintve a piridin hemokróm spektrum mérési eredményét, ez a változás a nemenzimatikusan érő citokróm $c$ hemjének - a natívval azonos kovalens kötés melletti minimális környezeti és/vagy geometriai eltérését mutatja a natívtól, amely tény redukciós hajlamában is befolyásolja a fehérjét.

A nem-enzimatikusan érö citokróm c funkcionalitásának vizsgálata: elektrontranszfer aktivitásának paraméterei

A redukciós potenciál megállapításán túl egyéb, funkcionalitásra vonatkozó, kísérleteket is végrehajtottunk ahhoz, hogy a hem közvetlen környezetét érintő változásoknak a mértékéről ismereteket szerezzünk.

Aktivitás-méréseket végeztünk COX-szal, a citokróm $c$ fiziológiás elektronakceptor partnerével. A 17. ábrán az oldatbeli oxigénfogyás kezdeti sebessége látható a szubsztrát citokróm $c$ koncentrációjának függvényében, mind az enzimatikus, mind pedig a nemenzimatikusan érő fehérje esetére. Az aktivitást leíró paramétereket (a $\mathrm{K}_{\mathrm{m}}$-et és a $\mathrm{V}_{\max }$-ot) a Michaelis-Menten összefüggés illesztésével kaptuk meg, amelyeket az 1. táblázatban 
tüntettük fel. A citokróm $c$ szubsztrátnak a COX enzimhez való affinitásáról a MichaelisMenten konstans $\left(\mathrm{K}_{\mathrm{m}}\right)$ értéke szolgáltat információt. Ez az érték a nem-enzimatikusan érő citokróm $c$ esetében magasabb, mint amit az enzimatikus fehérjével mértünk, ami a nemenzimatikusan érő citokróm $c$ valamivel gyengébb komplexképződési hajlamát mutatja.

A COX enzim négy darab redukált citokróm $c$ (egy - egy elektront szállítva a COXhoz) oxidációja révén redukál egy oxigénmolekulát vízzé, ezért a redukált citokróm $c$ (szubsztrát) fogyási sebessége a mért oxigénfogyás sebességének a négyszerese. Az irodalomban bevett szokásnak megfelelően a $\mathrm{V}_{\max }$ értékét, ami végtelen szubsztrátkoncentráció esetén az oxigénfogyás sebességének maximális kezdeti értéke $\left(\left(\mu \mathrm{mol} \mathrm{O}_{2}\right) /\right.$ perc $)$, osztjuk az enzim $(\mathrm{COX})$ mg-ban megadott mennyiségével. A nemenzimatikus és enzimatikus fehérjék $V_{\max }$ értéke gyakorlatilag hibahatáron belül megegyezik.

Összességében megállapítható a fenti aktivitási kísérletből, hogy a nemenzimatikusan érő citokróm $c$ fiziológiás fizikai-kémiai paraméterekkel rendelkezik.

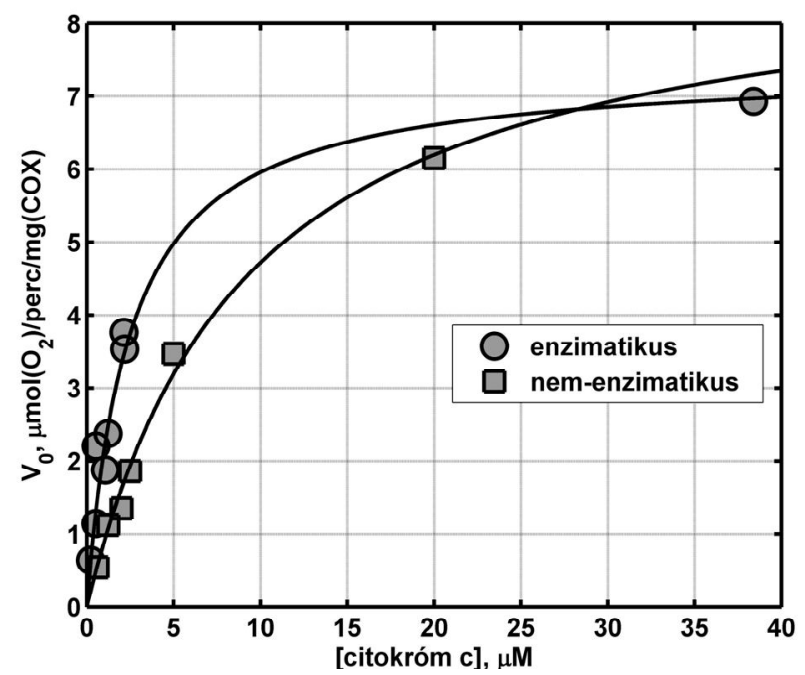

17. ábra. Az oxigénfogyás kezdeti sebessége a citokróm $c$ koncentrációjának függvényében oxigráffal végzett kísérletekben. Enzimatikusan érlelt citokróm $c$ (kör), illetve nem-enzimatikusan érő citokróm $c$ (négyzet). A folytonos vonalak a Michaelis-Menten egyenlet, $\mathrm{V}_{0}=\mathrm{V}_{\max }$ [citokróm $c] /\left(\mathrm{K}_{\mathrm{m}}+[\right.$ citokróm $\left.c]\right)$, illesztései.

A nem-enzimatikusan érő citokróm c funkcionalitásának vizsgálata: autoxidációs kísérlet

A szerkezeti és funkcionális integritás további vizsgálatára autoxidációs kísérletet is végeztünk a nem-enzimatikusan érő, az enzimatikusan érő és az autentikus citokróm $c$ redukált formáival. A hem oxidálódásának sebessége mindhárom típus esetében hasonló mértékü volt, ami szintén a hem-környezet oly kismértékü változására utal, amely a fehérje tulajdonságait és funkcióját lényegesen nem befolyásolja. 


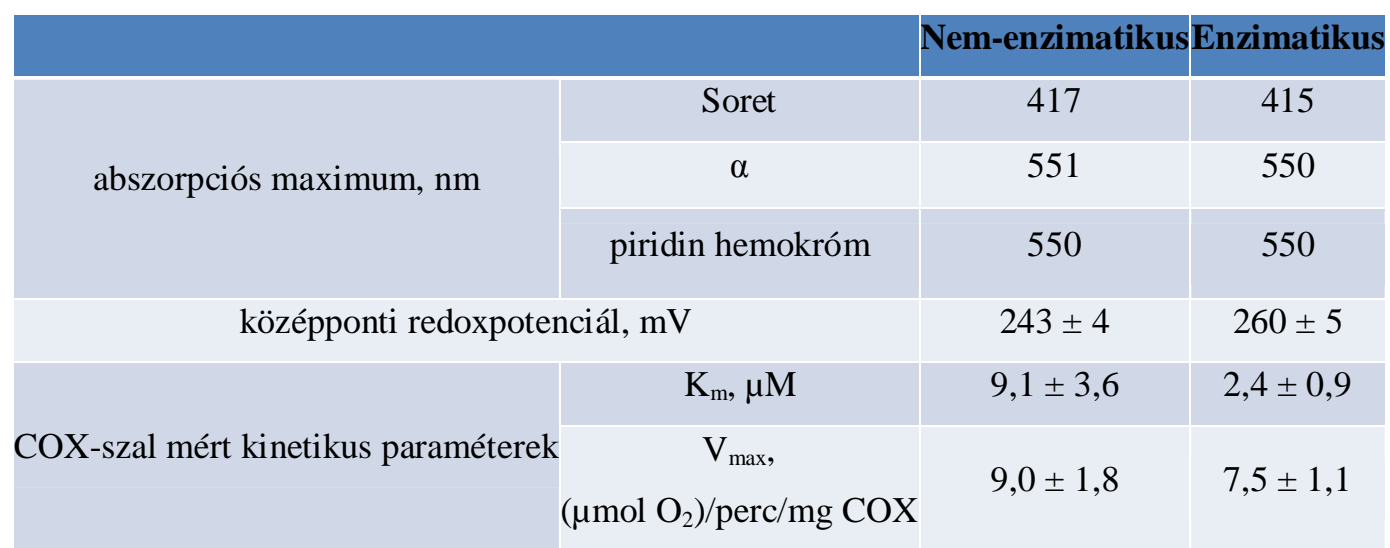

1. táblázat. A nem-enzimatikusan érő és az enzimatikus $c$ típusú citokrómok fizikai-kémiai paraméterei.

A nem-enzimatikusan érő citokróm c hemjének enyhén megváltozott molekuláris környezete és/vagy geometriája van

A nem-enzimatikusan érő citokróm $c$ közeli UV és látható hullámhossztartományban felvett oxidált és redukált abszorpciós spektrumait összehasonlítva az autentikus fehérje spektrumaival minimális változásokat vehetünk észre a Soret és a Q sávban. Azonban, ha az oxidált spektrumoknak a közeli IR tartományban mérhető 695 nmes, töltéstranszferre jellemző csúcsát vesszük figyelembe, a különbség lényegesebb. A 695 nm-es csúcs, amelynek megléte a natív fehérje oxidált vasának 80-as metionin általi koordinációját jelenti, a nem-enzimatikusan érő citokróm $c$ spektrumából teljesen hiányzik (18. ábra). A 695 nm-es csúcs a CCHL érlelte fehérje spektrumában viszont jelen van.

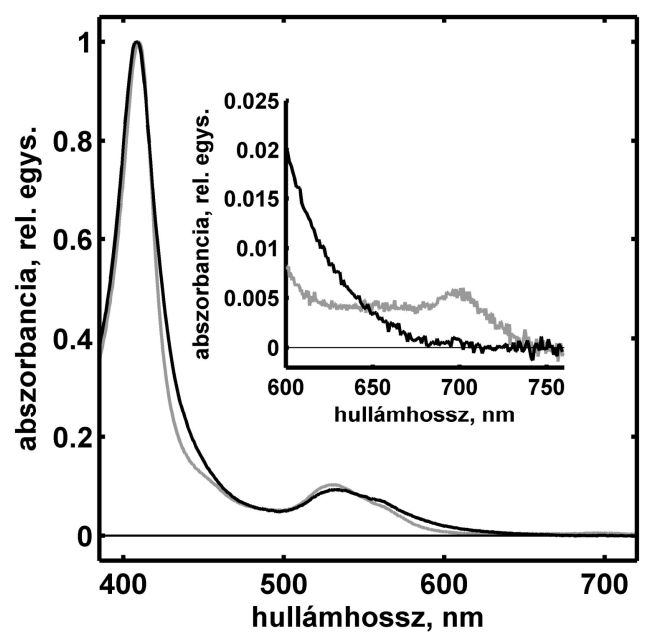

18. ábra. Közeli UV, látható és közeli infravörös hullámhossz-tartományokban felvett oxidált holocitokróm $c$ spektrumok:

Fekete vonal: BL21-AI E. coli törzsben nem-enzimatikusan érö citokróm $c$.

Szürke vonal: autentikus citokróm $c$.

A spektrumok a Soret csúcs maximumára vannak normálva, egy kis amplitúdójú szórásspektrum kivonása után. 
A redukált autentikus és rekombináns fehérjék spektrumainak eltérése pár nm, a nem-enzimatikusan érő citokróm $c$ spektrumának Soret csúcsa 415 nm helyett 417 nm-en van, a Q sáv 550 nm-es csúcsa pedig 551 nm-re tolódott (15. ábra, e). A két különböző $E$. coli törzsböl (BL21-AI és EC06) tisztított nem-enzimatikusan érő citokróm $c$ spektruma egyformán tolódott el.

A spektrális eltolódás részletes vizsgálata érdekében a Q sávot, amely a redukált fehérje spektrumában $\alpha$ és $\beta$ csúcsokra bomlik, Gauss összetevőire bontottuk.

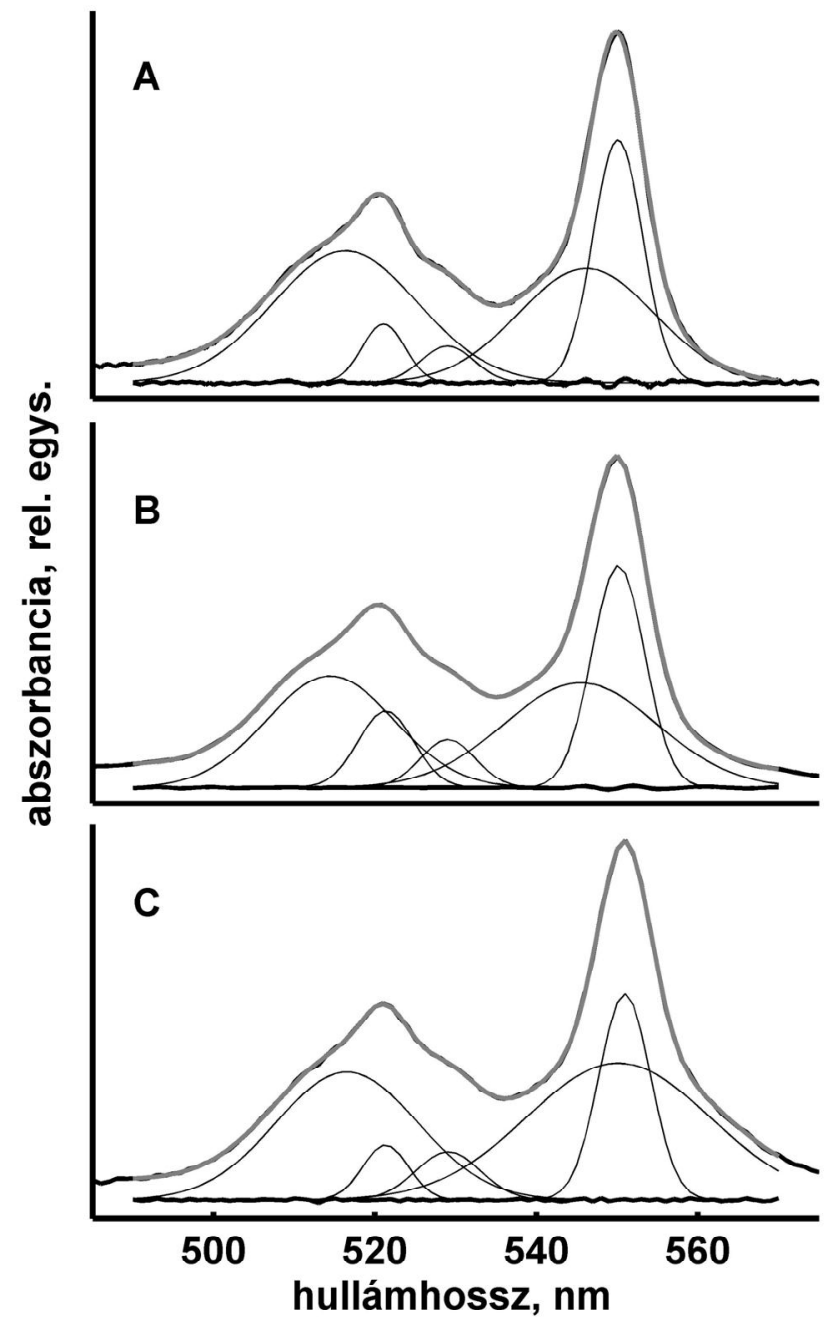

19. ábra. A redukált holocitokróm $c$ spektrumok Gauss komponensei:

A: Autentikus, ló szívizom citokróm $c$.

B: BL21-AI E. coli törzsből tisztított enzimatikusan érő citokróm $c$.

C: BL21-AI E. coli törzsből tisztított nem-enzimatikusan érő citokróm $c$.

Fekete vonal: mért spektrum. Szürke vonal: illesztés, amely a mért spektrumot tökéletesen fedi. Fekete vízszintes vonal: az illesztés maradéka. Vékony szürke vonalak: Gauss komponensek. 
A 19. ábrán látható és a 2. táblázatban egyaránt feltüntetett adatok alapján a különböző eredetü citokróm $c-\mathrm{k}$ Q sávjai ugyanazzal az ötféle, viszont amplitúdóban, pozícióban és szélességben kissé különböző spektrális komponensekkel illeszthetőek. A nem-enzimatikus citokróm $c$ redukált abszorpciós spektrumának (1 nm-es) $\alpha$ eltolódása megfigyelhető a Gauss komponenseken is. A legnagyobb mértékű eltolódást és különbséget a 4-es komponens mutatja: 4 nm-es eltolódása van a hosszabb hullámhosszak irányába és megnövekedett az amplitúdója és a szélessége is. Ez a komponens járul hozzá leginkább a nem-enzimatikusan érő citokróm $c$ natívhoz viszonyított kismértékü, de karakterisztikus spektrális eltolódásához.

\begin{tabular}{|c|c|c|c|c|}
\hline \multicolumn{2}{|c|}{ Minták } & Autentikus, ló szív- & CCHL-lel érő & Nem-enzimatikusan \\
\hline \multirow{3}{*}{$\begin{array}{c}1 . \\
\text { komponens }\end{array}$} & Pozíció, nm & $516,3(0,59)$ & $514,4(0,47)$ & $516,5(0,61)$ \\
\hline & Amplitúdó, \% & $22,5(0,63)$ & $19,7(0,64)$ & $22,2(0,78)$ \\
\hline & Szélesség, nm & $21,2(0,9)$ & $18,6(0,6)$ & $20,5(0,8)$ \\
\hline \multirow{3}{*}{$\begin{array}{c}2 . \\
\text { komponens }\end{array}$} & Pozíció, nm & $521,0(0,13)$ & $521,3(0,19)$ & $521,3(0,19)$ \\
\hline & Amplitúdó, \% & $10,1(1,05)$ & $13,7(1,50)$ & $9,6(1,03)$ \\
\hline & Szélesség, nm & $6,1(0,4)$ & $8,0(0,5)$ & $6,6(0,5)$ \\
\hline \multirow{3}{*}{$\begin{array}{c}3 . \\
\text { komponens }\end{array}$} & Pozíció, nm & $529,0(0,24)$ & $529,0(0,28)$ & $529,0(0,31)$ \\
\hline & Amplitúdó, \% & $6,3(1,26)$ & $8,6(0,64)$ & $8,5(1,55)$ \\
\hline & Szélesség, nm & $7,8(0,8)$ & $8,0(0,6)$ & $9,4(0,9)$ \\
\hline \multirow{3}{*}{$\begin{array}{c}4 . \\
\text { komponens }\end{array}$} & Pozíció, nm & $546,2(0,30)$ & $545,5(0,24)$ & $550,1(0,12)$ \\
\hline & Amplitúdó, \% & $19,5(0,63)$ & $18,6(0,43)$ & $23,8(0,52)$ \\
\hline & Szélesség, nm & $19,8(0,6)$ & $22,4(0,6)$ & $26,6(1,5)$ \\
\hline \multirow{3}{*}{$\begin{array}{c}5 . \\
\text { komponens }\end{array}$} & Pozíció, nm & $550,1(0,02)$ & $550,1(0,02)$ & $551,0(0,02)$ \\
\hline & Amplitúdó, \% & $41,6(0,63)$ & $39,4(0,43)$ & $35,9(0,78)$ \\
\hline & Szélesség, nm & $7,30(0,07)$ & $7,77(0,07)$ & $7,54(0,09)$ \\
\hline
\end{tabular}

2. táblázat. Az autentikus, a CCHL-lel és a nem-enzimatikusan érő redukált $c$ típusú citokrómok Qsávjának felbontása Gauss összetevőkre. A Gauss sávok táblázatban szereplő paramétereinek hibaértékei zárójelben vannak feltüntetve. A szélességek a félmagasságnál mért teljes szélességet jelentik (full width at half maximum, FWHM). 


\section{A CCHL túltermelésének feltételei, az enzim tisztítása, szerkezeti és spektrális jellemzése}

\section{A CCHL túltermelése és tisztítása}

A 6 hisztidin affinitás-peptiddel ellátott CCHL expressziója a pCS315 plazmidban tac promóter/lac operátor szabályozó rendszer kontrollja alatt történt, IPTG indukcióval. A CCHL az E. coli citoplazmájában kicsapódik, amelyet az alábbi 10 és $30{ }^{\circ} \mathrm{C}$-on, ez utóbbin időfüggően, elvégzett expressziós vizsgálatok is bizonyítanak (20. ábra, A és B). $1 \mathrm{mM}$ IPTG-vel indukált CCHL expressziójához az ideális hőmérséklet és időtartam: $30{ }^{0} \mathrm{C}$ és 3 óra. Natív konformációban nagyon kis mennyiségben tisztítható. A túltermeltetett enzimmennyiséghez képest a szolubilis frakcióból tisztítható CCHL mennyisége minimális, hozama $1 \mathrm{~g}$ nedves sejtre vonatkoztatva $\sim 0,25 \mathrm{mg}$.

A

B
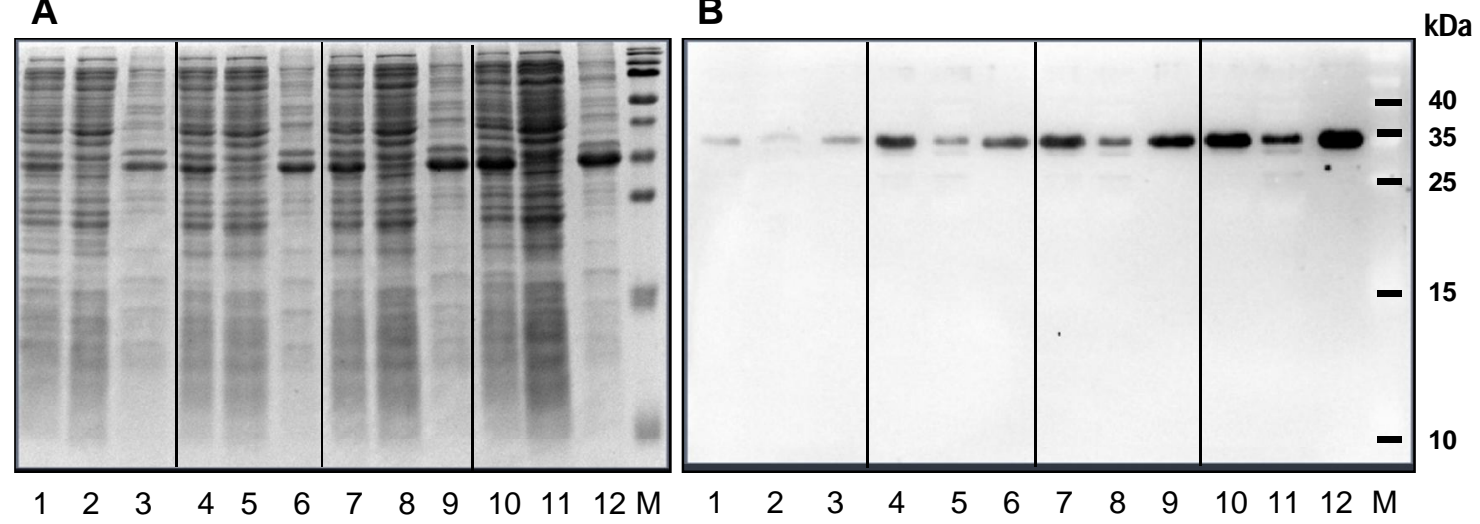

20. ábra. His ${ }_{6}$ peptiddel fuzionált CCHL expressziójának vizsgálata. Expresszió: $10{ }^{0} \mathrm{C}$-on és időfüggő módon $30^{\circ} \mathrm{C}$-on. Indukció: $1 \mathrm{mM}$ IPTG-vel:

A: $15 \%$-os SDS poliakrilamid gél, Coomassie BB G-250 festés.

B: His $_{6}$ peptiddel fuzionált CCHL immunodetektálása nitrocellulóz membránon torma peroxidázzal konjugált $\mathrm{His}_{6}$ antitesttel.

$\underline{1-3}: 10{ }^{0} \mathrm{C}, \mathrm{OVN}, \underline{1}$. teljes sejtextraktum $(50 \mathrm{mg} / \mathrm{ml}), 2,5 \mu \mathrm{l} ; \underline{2}$. szolubilis frakció, $5 \mu \mathrm{l} ; \underline{3}$. üledék 5 $\mu 1$.

$\underline{4-5}: 30{ }^{\circ} \mathrm{C}, 1$ órás inkubációs idő, $\underline{4}$. teljes sejtextraktum $(50 \mathrm{mg} / \mathrm{ml}), 2,5 \mu \mathrm{l} ; \underline{5}$. szolubilis frakció, 5 $\mu \mathrm{l} ; \underline{6}$. üledék $5 \mu \mathrm{l}$.

$\underline{7-9}$ : $30{ }^{0} \mathrm{C}, 2$ órás inkubációs idő, $\underline{7}$. teljes sejtextraktum $(50 \mathrm{mg} / \mathrm{ml}), 2,5 \mu \mathrm{l} ; \underline{8}$. szolubilis frakció, 5 $\mu 1 ; \underline{9}$. üledék $5 \mu 1$.

$\underline{10-12:} 30{ }^{\circ} \mathrm{C}, 3$ órás inkubációs idő, $\underline{10}$. teljes sejtextraktum $(50 \mathrm{mg} / \mathrm{ml}), 2,5 \mu \mathrm{l} ; \underline{11}$. szolubilis frakció, $5 \mu \mathrm{l}$; 12 . üledék $5 \mu \mathrm{l}$. … fehérje létra, Fermentas SM0671.

\section{A tiszta CCHL vizsgálata}

A His 6 fuzionált CCHL enzimet affinitás-kromatográfiával nikkel keláló Sepharose tölteten tisztítottuk. Tisztaságvizsgálat céljából denaturáló poliakrilamid gélen megfuttattuk a tiszta fehérjeoldatot (21. ábra, A és B). 


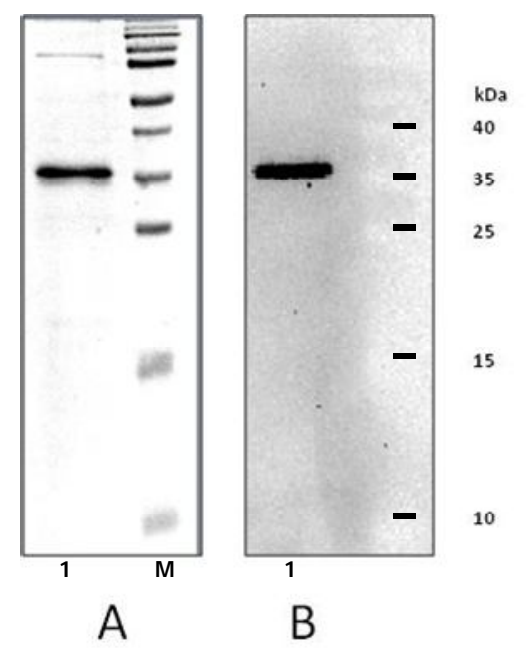

21. ábra. His $_{6}$ peptiddel fuzionált CCHL tisztaságának vizsgálata:

A: $15 \%$-os SDS poliakrilamid gél, Coomassie BB G-250 festés.

B: His ${ }_{6}$ peptiddel fuzionált CCHL immunodetektálása nitrocellulóz membránon torma peroxidázzal konjugált $\mathrm{His}_{6}$ peptid antitesttel.

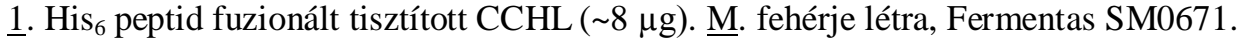

Megmértük a minta UV abszorpciós spektrumát (22. ábra), amelyből hozamot és a későbbi spektrális, illetve in vitro kísérletekhez koncentrációt tudtunk számolni. Az aromás aminosavak tartományában felvett spektrum tipikus fehérjespektrumnak felel meg. A CCHL 269 aminosavja közül ebben a tartományban a 3 tirozin, a 7 triptofán, a 11 fenilalanin és a 4 cisztein abszorbeál. Tekintettel a triptofán nagy extinkciójára a spektrumot a triptofán 280 nm-es abszorpciós csúcsa uralja (Cantor 1980).

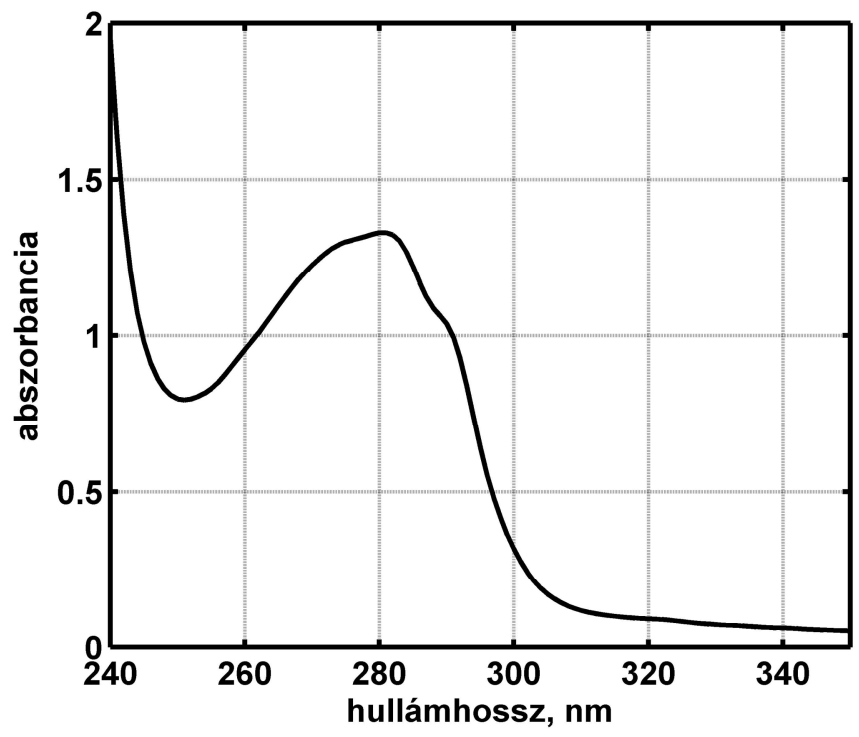

22. ábra. A tiszta $\mathrm{His}_{6}$ peptiddel fuzionált CCHL UV abszorpciós spektruma. 


\section{A CCHL szerkezeti jellemzése}

A 31 kDa fúziós fehérje következetesen a létra 35 kDa-os fehérjéjének magasságába szaladt, ami arra utalhat, hogy a CCHL legalább részben rendezetlen szerkezetü fehérje (IDP - Intrinsically Disordered Protein vagy IUP - Intrinsically Unstructured Protein). A teljes egészében rendezetlen vagy nagyobb rendezetlen szakaszokat tartalmazó fehérjék sajátos aminosav-összetételüknél fogva kevesebb SDS detergenst kötnek meg, ezért szeparálás során adott idő alatt rövidebb utat tesznek meg, mint a hasonló méretü, de rendezett szerkezetü fehérjék (Tompa 2002). Ezért a denaturáló körülmények között végzett szeparációs módszer alkalmas többek között arra is, hogy a fehérje szerkezetéről (esetleg a rendezett szerkezet hiányáról) közvetett módon információkkal szolgáljon.

Az SDS-PAGE kísérletek eredményéből kiindulva a CCHL aminosav-szekvenciáján többféle programmal is végeztünk szerkezet-predikciós vizsgálatot. Az IUPred program a CCHL - CPV motívumokat is tartalmazó - N-terminális szakaszát 67 aminosav hosszúságban (14 - 80) rendezetlen szerkezetü doménnek jósolja, ami a teljes hossz 25 \%ának felel meg (23. ábra). Ugyanakkor vannak olyan szakaszok is (pl. 81 - 114, továbbá a szekvencia két végén), melyek a szerkezeti diszkrimináció határértékét jelentő 0,5-ös érték körül mozognak. A program a fehérje kb. 50 \%-át jósolja csak nagy biztonsággal másodlagos szerkezettel rendelkezőnek. Egy másik szerkezetvizsgáló program, a DisProt (Sickmeier 2007) segítségével még az IUPred program által jósoltnál is hosszabb, összefüggő rendezetlen szerkezetü (disordered) tartományt találtunk a 16. és 107. aminosavak között.

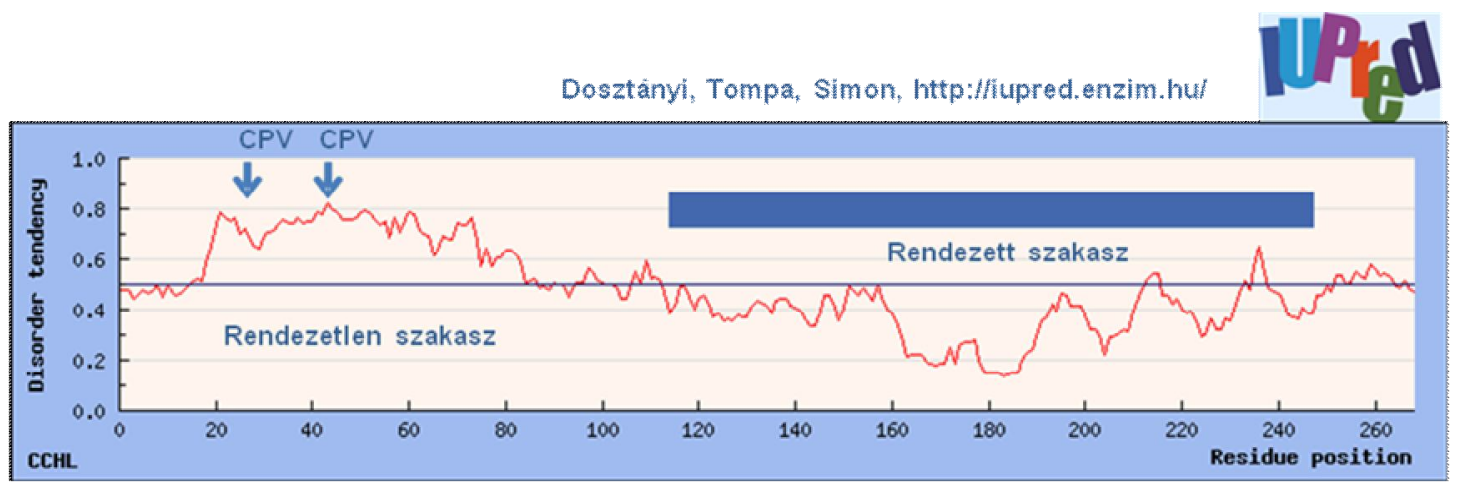

23. ábra. A CCHL szerkezetének vizsgálata az IUPred rendezetlenséget prediktáló programmal.

Rendezetlen szerkezetre vonatkozó predikciót végeztünk a CCHL homológ fehérjéin is. A homológokat a BLAST program segítségével azonosítottuk. Ahogy az a 24. ábrán látható, a homológ fehérjék mindegyike tartalmaz - a predikció szerint - rendezetlen szakaszt az N-terminális végéhez közel, és ennek hossza a teljes hossz $25 \%$-a és $61 \%$-a 
között változik. Ugyancsak jellemző, hogy egy kivétellel minden homológ tartalmaz 1 vagy 2 CPV hemszabályozó motívumot, és minden esetben a rendezetlennek jósolt doménben.
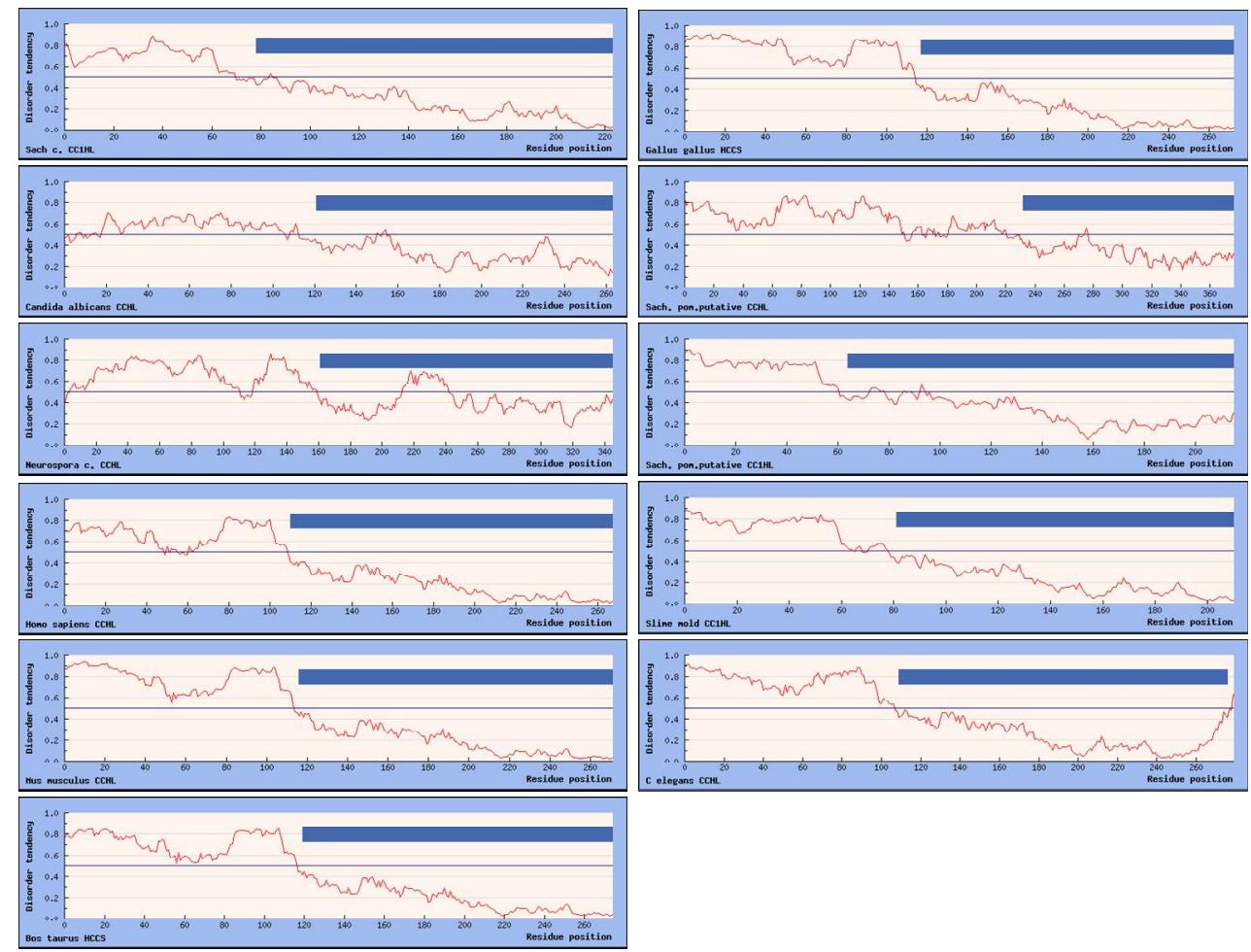

24. ábra. $\mathrm{Az}$ élesztő CCHL-lel homológ fehérjék szerkezetének vizsgálata az IUPred rendezetlenséget prediktáló programmal. A homológ fehérjék a baloldali oszlopban, majd a jobboldaliban felülről lefelé haladva a következők: Saccharomyces cerevisiae $\mathrm{CC}_{1} \mathrm{HL}$, Candida albicans CCHL, Neurospora crassa CCHL, Homo sapiens HCCS, Mus musculus HCCS, Bos taurus HCCS, Gallus gallus HCCS, Schizosaccharomyces pombe feltételezett CCHL, Schizosaccharomyces pombe feltételezett $\mathrm{CC}_{1} \mathrm{HL}$, Slime mold CCHL, Caenorhabditis elegans CCHL.

A rendezetlen szerkezetü fehérjék aminosav-összetételében általában legalább kétszeres osztóval kisebb a száma a rendezettséget elősegítő aromás- és hidrofób-oldalláncú aminosavaknak, vagy éppen teljesen hiányozhatnak is. Gyakoriak viszont a rendezetlenséget elősegítő, mint pl. a töltött vagy a poláros oldalláncú aminosavak (Tompa 2009).

Összetétel szempontjából elemeztük a hem liáz 269 aminosavból álló szekvenciáját, és azt vettük észre, hogy a jellemzően rendezettséget vagy épp rendezetlenséget elősegítő aminosavak közül néhány a megfigyeléseknek megfelelően oszlik meg a CCHL rendezetlennek jósolt (14 - 80) és összes többi szakasza között. A 7 darab triptofán és a 11 darab fenilalanin mind a fehérje 75 százalékát kitevő határozottan rendezett vagy „határeset” szakaszában található. A rendezetlennek vélt szakaszból hasonlóképpen hiányzik a tirozin, és a 7 darab treoninból csak egy található ebben a szakaszban. A 
rendezetlenséget segítő aminosavak közül a szerin aránya tekintélyes a 25 \%-ot kitevő rendezetlen szakaszban, közel $18 \%$-át teszi ki, a 29 szerinből 12 található ebben a szakaszban. Egy másik rendezetlenséget elősegítő aminosav, a prolin, a fehérje teljes szekvenciájában gyakori, a rendezetlen résznek pedig 12\%-át prolinok alkotják.

\section{A CCHL UVCD spektruma és várható másodlagos szerkezeti összetétele}

A CCHL másodlagos szerkezetének vizsgálata céljából megmértük a fehérje UV cirkuláris dikroizmus spektrumát (25. ábra). A spektrumot illesztettük a másodlagos szerkezeti összetétel becslése céljából. A CDTOOL program (Lees 2004) által szolgáltatott százalékos arányok a következők:

\begin{tabular}{|c|c|c|c|c|c|}
\hline$\underline{\text { Szabályos- } \alpha}$ & $\underline{\text { Szabálytalan- } \alpha}$ & $\underline{\text { Szabályos- } \beta}$ & $\underline{\text { Szabálytalan- } \beta}$ & „,Turns” & $\underline{\text { Rendezetlen }}$ \\
\hline 13,7 & 12,2 & 16,5 & 8,6 & 13,3 & 35,7 \\
\hline
\end{tabular}

3. táblázat. A másodlagos fehérjeszerkezeti elemek százalékos aránya a CCHL UV CD spektrumának illesztése alapján.

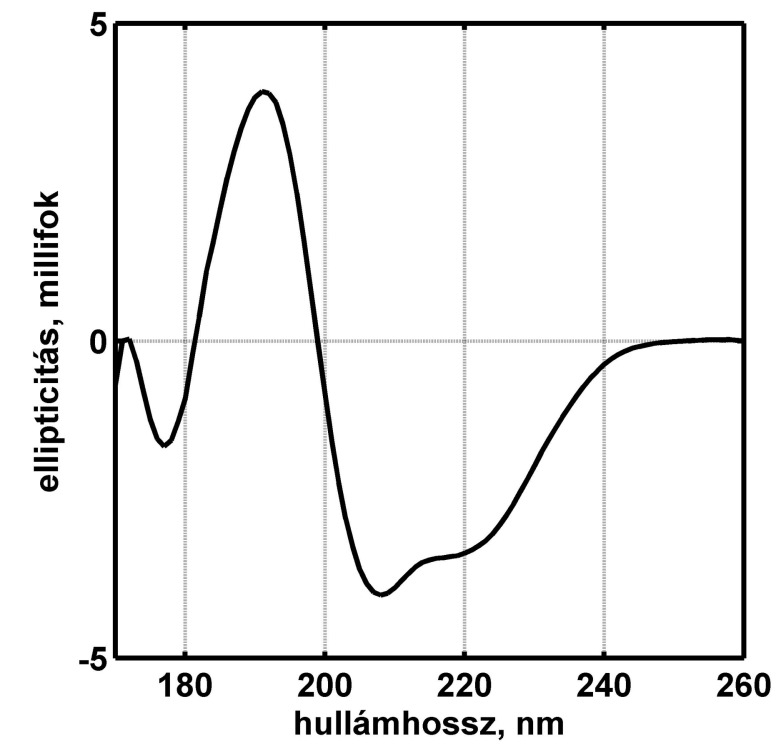

25. ábra. A CCHL UV cirkuláris dikroizmus spektruma.

A szabálytalan $\alpha$ és $\beta$ szerkezetek az $\alpha$-hélixek és a $\beta$-lemezek végein elhelyezkedő és ezért már nem teljesen szabályos geometriájú és hidrogénhíd-kötésü - aminosavak hozzájárulását jelentik a CD spektrumhoz (Sreerama 1999). Ettől eltekintve ezeket az elemeket az $\alpha$-hélixek, illetve $\beta$-lemezek részeinek lehet tekinteni, így tehát a fehérjeösszetételben a teljes $\alpha$-hélix 25,9\%-nak, a teljes $\beta$-lemez pedig 25,1 \%-nak adódik.

A rendezetlen rész 35,7 \%-os hozzájárulása összhangban áll az IUPred program által jósolt mennyiséggel. A natív körülmények között tisztított CCHL-lel ellentétben a 
denaturáló körülmények között tisztított, majd renaturált CCHL CD spektruma különbözött a fenti spektrumtól. Ebben a mintában jelentősen nagyobbnak adódott a rendezetlen hozzájárulás. Világos tehát, hogy a fehérje natív szerkezete ilyen körülmények között nem állítható maradéktalanul helyre, ezért további kísérleteinkben csak a natív körülmények között tisztított fehérjével dolgoztunk. A 25. ábrán láthatóhoz teljesen hasonló spektrumot mértünk a natív körülmények között tisztított CCHL-en Na-foszfát és HEPES puffer, valamint $\mathrm{NaF}$ jelenlétében (a $\mathrm{NaF}$ alkalmasabb az UV CD mérésekben a NaCl-nál a só esetleges stabilizáló hatásának vizsgálatára, mivel a $\mathrm{F}^{-}$-ion - ellentétben a $\mathrm{Cl}^{-}$-ionnal - nem abszorbeál az UV-ben). Ugyancsak változatlannak találtuk a CCHL CD spektrumát $10 \mu \mathrm{M}$ hem hozzáadása után is. A hemnek önmagában ebben a hullámhossz-tartományban nincs hozzájárulása a $\mathrm{CD}$ spektrumhoz. A hem jelenlétében mért, a fentihez hasonló CCHL CD spektrum arra enged következtetni, hogy mérhető mértékü másodlagos szerkezetváltozás (értendő ez alatt a másodlagos szerkezeti elemek arányában beálló változás) nem következik be a fehérjében a hemmel való kölcsönhatása során.

\section{A CCHL hem kötésének vizsgálata}

A CCHL és a hem lehetséges kölcsönhatásának vizsgálatára in vitro kísérletet végeztünk. A kölcsönhatást a hemre jellemző abszorpciós spektrum változásával mutattuk ki a Soret sávban és a látható spektrumtartományban. A reakció két fázisra bontható, az első fázisban az UV tartományban van egy abszorpció-csökkenés, a szabad hem fogyásának köszönhetően. A második fázisban pedig ez a csökkenés tovább fokozódik és a koordinált hemre jellemző Soret (422 nm), $\alpha$ (559 nm) és $\beta$ (532 nm) sávok alakulnak ki (26. ábra, A).

A

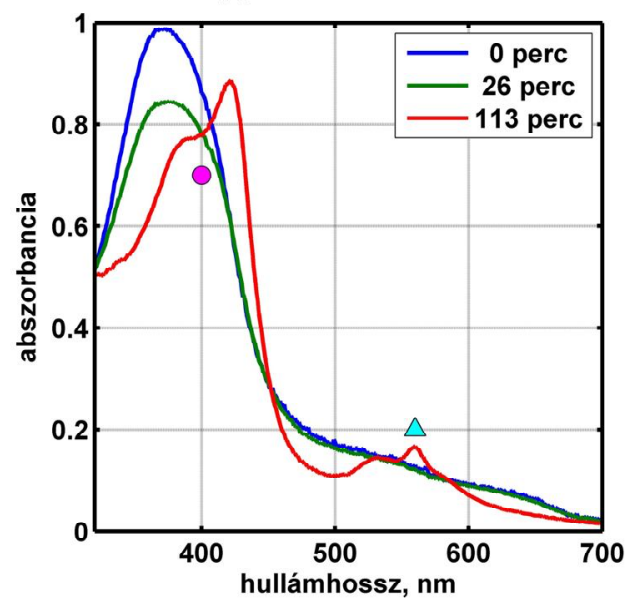

B

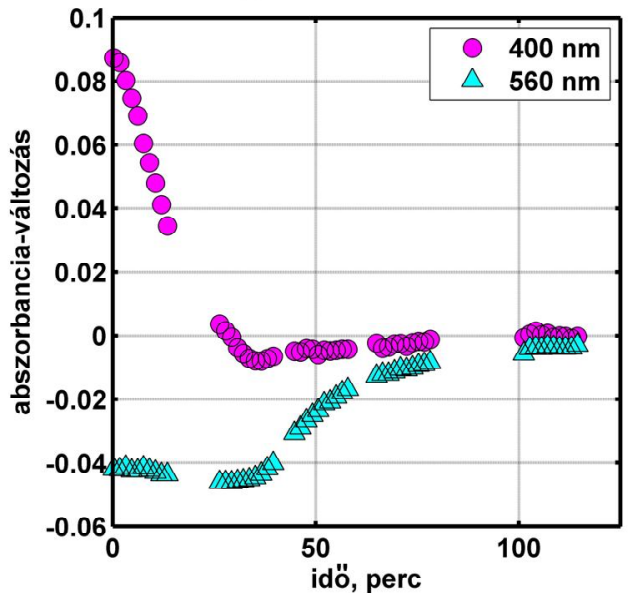

26. ábra. A CCHL és hem kölcsönhatásának időfüggő abszorpciós spektrumai és kinetikája két jellegzetes hullámhosszon:

A: A CCHL és hem keverékének UV és látható hullámhossz-tartományú spektumai.

B: A reakció során két jellegzetes hullámhosszon történő időbeli spektrális változások. 
A 26. ábra B paneljén két jellegzetes hullámhosszon (400 és $560 \mathrm{~nm}$ ) történő abszorpcióváltozást ábrázoltunk az idő függvényében. $400 \mathrm{~nm}$-nél az első folyamat tanulmányozható elkülönítve, mivel a másodiknak itt izobesztikus pontja van. Az $560 \mathrm{~nm}$-es spektrumváltozás pedig csak a második folyamatról tudósít. Az irodalomból ismert tripszines emésztés és az IUP predikció eredményének tükrében a reakció kinetikája az alábbiakban magyarázható. A reakció első fázisában (10 - 20 perc alatt) a szabad hem kölcsönhatásba lép a CCHL-lel, feltételezésünk szerint az N-terminális rendezetlen szakaszával. A második fázisban (ami kb. 1 óra) valószínü, hogy a szakasz CPV motívumainak cisztein-oldalláncai a hem vasát koordinálják. A kialakult spektrum ugyanis azt valószínüsíti, hogy a hem 6-szorosan koordinált, alacsony spinü állapotba került.

\section{A mitokondriális citokróm $c$ in vitro enzimatikus érése}

A His ${ }_{6}$ peptiddel fúzionált CCHL müködőképességét korábban in vivo rekombináns citokróm $c$ érésével bizonyítottuk, amikoris a holocitokróm $c$ termeléshez a BL21-AI $E$. coli törzset kotranszformáltuk a CCHL és a vele kompatibilis, citokróm $c$ génjét tartalmazó, plazmidokkal és IPTG, valamint arabinóz indukcióval expresszáltuk a fehérjéket.

A CCHL holocitokróm $c$ szintetáz aktivitásának, valamint az ehhez szükséges feltételeknek a vizsgálatára in vitro kísérleteket végeztünk a tisztított rekombináns CCHLlel és ló szívizom apocitokróm $c$-vel (27. ábra).



27. ábra. In vitro érési kísérlet. A reakcióelegy abszorpciós spektruma ditionit hozzáadása elött (kék), ditionit hozzáadása után közvetlenül (piros) és 40 perc inkubálás után (fekete). 
A kísérlethez az apocitokrómot a ló szívizom holocitokróm $c$ hemjének az eltávolítása után kaptuk. A reakcióhoz CCHL és apocitokróm $c$ fehérjekeveréket készítettünk, amelyet tiol-redukáló ágenssel, ditiotreitollal kezeltünk az apofehérje esetleges diszulfid-hídjainak a felszakítására. A fehérje elegyhez adtuk a hemet, majd később kristályos Na-ditionit hozzáadásával indítottuk a reakciót. A nitrogén atmoszférájú lezárt küvettát egy órán keresztül inkubáltuk folyamatos spektrummérés mellett.

A reakcióból bizonyos időközökben mintát vettünk, amelyeket denaturáló gélen megfuttattunk és gélben a hem peroxidáz-aktivitásából származó kemilumineszcenciás jelet detektáltuk, a kovalens kötés igazolására. A reakció első pár másodpercében, a legelső spektrum felvételekor a hemnek nagyon minimális jele van, a reakció 10 perce és 1 órája között felvett hem-jel intenzitása gyakorlatilag nem változik (28. ábra). Az abszorpciós spektrum szintén jól mutatja a citokróm $c$-re jellemző tulajdonságokat, különösen az 550 nm-nél lévő $\alpha$ sávot. A spektrum keverékspektrum kell, hogy legyen, mert a hem mennyisége az elegyben az apocitokróm $c$ mennyiségének a kétszerese volt. Ennek megfelelően az $\alpha, \beta$ és a Soret sávok nem annyira élesek, mint a tiszta citokróm $c$ esetében. Mindazonáltal a mintákon SDS gél-elektroforézist követően sikerült kemilumineszcenciás jelet detektálni, ami egyértelműen azt bizonyítja, hogy a hem egy része kovalensen és a spektrum alapján sztereospecifikusan, azaz helyesen kötődött az apocitokrómhoz.

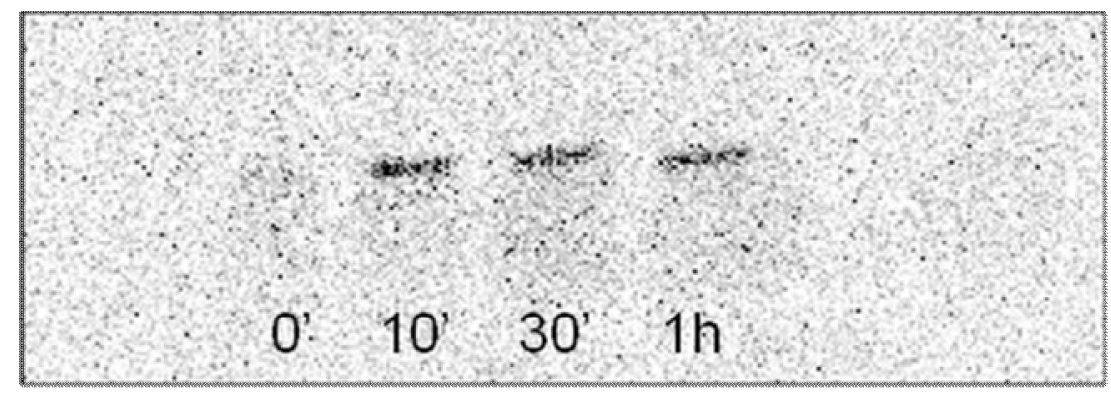

28. ábra. Az in vitro körülmények között, enzimatikusan érő holocitokróm $c$ kemilumineszcenciás jele, amely a hem kovalens kötésének bizonyítékául szolgál. $15 \%$-os SDS poliakrilamid gél, Coomassie BB G-250 festés. A reakcióelegyböl összekeverés után rögtön, 10 és 30 perc után, valamint 1 óra után vett minták vannak megfuttatva.

A fenti reakció kontrolljaként apocitokróm $c$ és hem reakciót végeztünk, amely nem mutatta azt a spektrális változást, mint amit a CCHL jelenlétében láttunk (29. ábra), és hem kemilumineszcenciás jelet sem tudtunk detektálni a futtatott mintákon.

A kísérlet ideje alatt CCHL hiányában tehát a redukált hem egy része még nemkovalens kölcsönhatásra sem lépett az apocitokrómmal, ill. a hem és az apocitokróm között kialakult egy olyan nem-kovalens kölcsönhatás is, amely a hem vasának koordinációjával 


\section{Eredmények}

nem járt, és amely rövid idő alatt, a spektrális csökkenésből ítélve, szét is bomlott.

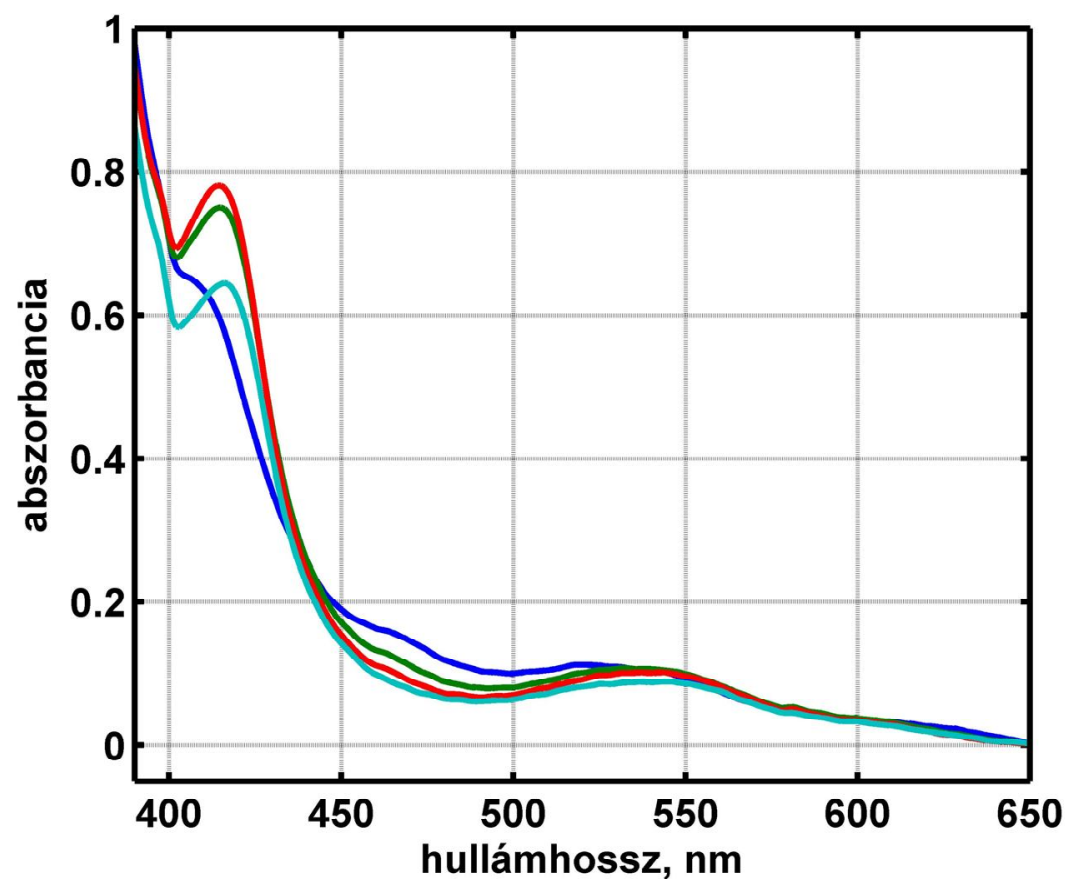

29. ábra. Az in vitro érés kontroll kísérlete CCHL nélkül, a reakció különböző időpontokban megmért abszorpciós spektrumai. Ditionit hozzáadása előtt (kék), ditionit hozzáadása után közvetlenül (zöld) 10 perc inkubálás után (piros) és 30 perc inkubálás után (cián). 


\section{Az eredmények megvitatása}

Az citokróm $c$ mutánsok előállításához szükséges expressziós rendszernek a kidolgozása nem csak a mi érdemünk, ennek előzményei vannak az irodalomból (Dolgikh 1998, Pollock 1998, Rumbley 2002), viszont mi a kísérleteink számára kidolgoztunk egy megbízható és nagy hozamot biztosító saját expressziós rendszert (Tenger 2007). Érdekessége a rendszernek, hogy eukarióta enzim érlel tökéletesen eukarióta fehérjét prokarióta citoplazmában.

Pollock és mtsi. (1998) bizonyították először, hogy az élesztő hem liáza bakteriális környezetben is elvégzi a citokróm $c$ érését. Rekombináns holocitokróm $c$ termelése érdekében elégséges, ha az apocitokrómot és az érlelő enzimet együtt expresszáljuk az $E$. coli-ban, mint heterológ gazdában. Semmilyen más külsőleg hozzáadott faktor nem szükséges az aktív holocitokróm $c$ expresszióhoz.

A saját expressziós rendszerben a citokróm $c$ és hem liáz génjeit tartalmazó kazettát, illetve a citokróm $c$ génjét a pBAD24 plazmid (Guzman 1995) szigorú szabályozást biztosító arabinóz promóterének és szabályozó régiójának ellenőrzése alá helyeztük. A szigorú szabályozás érdekében a plazmid hordozza a $\mathrm{P}_{\mathrm{BAD}}$ promóter negatív és pozitív kontrollját biztosító AraC fehérje génjét (Schleif 2000), amely konstrukció így magas indukált és rendkívül alacsony nem indukált expressziót biztosít számunkra. Emellett az arabinóz-koncentráció változtatásával az expresszió erőssége hangolható.

Nem tisztázott még a mitokondriális citokróm $c$ CCHL általi enzimatikus érésének a mechanizmusa, de az általunk végzett heterológ in vivo és in vitro kísérletek ismereteket szolgáltatnak a pontos molekuláris folyamatoknak a megértéséhez.

Kísérleteinkkel bizonyítottuk, hogy a CCHL közremüködése nélkül is, igaz lényegesen alacsonyabb hozammal, de képes a ló citokróm $c$ az $E$. coli citoplazmájában érni, oly módon, hogy helyes kovalens kötés alakul ki a hem vinilcsoportjai és a polipeptidlánc ciszteinjei között. Ez az első olyan munka, amely prokarióta közegben eukarióta citokróm $c$ enzimes asszisztencia nélküli éréséről szolgáltat bizonyítékot és ismereteket. Az E. coli citoplazmatikus membránjában elhelyezkedő, de a periplazmatikus oldalon működő maturációs rendszere nem lehet felelős az érésért, mert a fehérjénk polipeptidlánca nem tartalmazza azt a szignálpeptidet, amely által a fehérje a periplazmatikus oldalra szállítható (Thöny-Meyer 1997). A kísérleti feltételeink nem is kedveznek a Ccm rendszer kifejeződésének, ahhoz anaerob körülmények és nitrát, nitritek jelenléte szükséges (Choe 1993, Sanders 2000, Thöny-Meyer 2002). Azért a nem- 
enzimatikus érést olyan kontroll kísérlettel is igazoltuk, amelyben az E. coli EC06 (ThönyMeyer 1995) Ccm-mutáns törzset használtuk gazdának. Ez a törzs nem tartalmazza a müködőképes bakteriális érlelő rendszert, ezért kizárt, hogy valamilyen módon is a baktérium saját rendszere érlelné az általunk bevitt citokrómot.

CCHL jelenlétében, illetve hiányában az apocitokróm $c$ expressziós hozama egyforma, mivel ugyanazok a kísérleti körülmények, beleértve az expressziós konstrukciót és az $E$. coli törzset is. A citokróm $c$ nem-enzimatikus érése jóval lassabb folyamat, mint az enzimatikus érés. A CCHL hiányában termelődő apocitokróm $c$ folyamatos proteolitikus emésztésnek van kitéve, amit denaturáló gélelektroforézissel bizonyítottunk is, és így kinetikailag verseng egymással a citokróm $c$ termelődése és a lebomlás. A fehérjék tisztítása után adható hozzávetőleges hozambecslés alapján a nem-enzimatikusan érő citokróm $c \sim 2$ $\%$-a az enzimatikusan érőnek.

Daltrop és mtsi. (2002, 2003a, b) végeztek spontán érési kísérleteket bakteriális és eukarióta citokróm $c$ fehérjékkel, amelyek 48 és 72 órás inkubációs idő alatti in vitro vizsgálatokat jelentettek. A kísérleteinkben tapasztalt, enzimatikus közremüködés nélküli érést OVN spontán maturációnak is tekinthetjük, noha teljes bizonyossággal, a citoplazmatikus környezet miatt nem zárjuk, azaz nem zárhatjuk ki ismeretlen fehérje vagy nem fehérje-természetü faktorok közremüködését sem. Az irodalomban leírt, in vitro spontán érésű citokróm $c$ abszorpciós spektruma ugyan hasonló volt egy natív holocitokróm c spektrumához, de egyéb fizikai-kémiai paraméterek nem állnak rendelkezésre ahhoz, hogy funkcionálisan összehasonlíthassuk az általunk vizsgált, in vivo nem-enzimatikusan érő citokróm $c$-vel.

A nem-enzimatikusan érő citokróm $c$ kovalens hem kötését mindenekelőtt az SDS gél-elektroforézis során denaturálódott fehérje pozitív hem peroxidáz-aktivitási eredményével igazoltuk. Ha ugyanis a hem nem-kovalensen lenne kötve a citokrómban, akkor az SDS gélben nem maradna együtt a fehérjével. Ez a kísérlet ugyanakkor megengedné azt is, hogy a hem nem kétszeres, hanem csak egyszeres kötéssel kapcsolódjon a fehérjéhez. A hem helytelen orientációja, pl. elfordulása az $\alpha, \gamma$ mezo tengelye körül a hem nem megfelelő illeszkedését jelentené a polipeptidlánchoz viszonyítva, és ez egyszeres hem kötést eredményezne. Egy ilyen változás a kötésben és az orientációban jelentősebb spektrális eltolódást okozna a citokróm c spektrumában (Bowman 2008). A piridin hemokróm spektrum pedig világosan megmutatta, hogy a hemkötő motívum mindkét ciszteinjén keresztül köti a hemet, ami a hem helyes orientációjára utal. Egyszeres hemkötés esetén ugyanis az $\alpha$ csúcs piridin hemokróm spektruma 3 nm-el a hosszabb hullámhosszak 
felé lenne eltolódva (Tomlinson 2000b), amely eltolódás a nem-enzimatikusan érő fehérje piridin spektrumában nem észlelhető. Megállapíthatjuk tehát, hogy a nem-enzimatikusan érő fehérjében a hem kovalens kötése azonos a natív citokróm $c$ kettős tioéter kötésével.

A redukált citokróm $c$ abszorpciós spektruma egy, a hem, a központi vas, a ligandumok elektronikus és vibrációs energiái által meghatározott, karakterisztikus dupla csúcsú Q sávval rendelkezik, amelyet a hem közvetlen környezete is befolyásol. A nemenzimatikusan érő citokróm $c$ a natívhoz képest ugyan $1 \mathrm{~nm}$ spektrális eltolódást mutat, de jellegzetes erős axiális ligandumokkal hatszorosan koordinált, alacsony spinű citokróm $c$-re jellemző Q sávval rendelkezik. Hasonló mértékü vöröseltolódás ismeretes olyan élesztő iso1 citokróm $c$ mutánsok esetében, amelyekben a hem közvetlen környezetét érintő mutációk a prosztetikus csoport környezetének polaritását befolyásolták (Schweitzer-Stenner 2006). Magyarázatuk szerint a polaritásváltozás a hem gyürüjének elektronikus perturbációja révén okozta a spektrális elváltozást. Alacsony hőmérsékleten végzett abszorpciós és vibrációs spektroszkópiai (Levantino 2005) kísérletek azt mutatják, hogy a legalacsonyabb energiaátmenet (a nem-enzimatikusan érő citokróm $c$ esetében az 551 nm-es csúcs) megfelel az első gerjesztett állapot 0 - 0 vibronikus átmenetének, míg a Q sáv többi része ugyanezen elektronikus gerjesztés magasabb vibrációs sávjaiba való vibronikus átmeneteknek felel meg. Szobahőmérsékleten homogén és inhomogén kiszélesedése látható az alacsony hőmérsékletü Voigtian sávoknak, az így széthúzódott spektrumcsúcsok Gauss görbe alakot mutatnak. A natív, enzimatikusan és enzim nélkül érő citokróm $c$ spektrumok Q sávjai ugyanarra az öt Gauss görbére bonthatók fel. A Q sávjának Gauss felbontása a minta homogenitását és a natívval való hasonlóságát támasztja alá. A nem-enzimatikusan érő citokróm $c 1 \mathrm{~nm}$-es vöröseltolódása a natívhoz képest a legalacsonyabb energia-átmenet esetében minimális energiaszint-csökkenést jelent az alapállapot és az első gerjesztett állapot között. Az 551 nm-es csúcs vállát képező egyik Gauss görbe kiszélesedése olyan konformációs heterogenitásról árulkodhat, amely a natív, illetve az enzimatikusan érő fehérjék esetében nincs jelen, vagy csak nagyon kis mértékben. Ez jelentheti azonban az alapállapotú hem vibrációs szintjeinek a különböző populációját, amely szintén árulkodhat a nem-enzimatikusan érő citokróm $c$ hemjének enyhén megváltozott geometriájáról és/vagy környezetéről.

Az oxidált citokróm $c$-nek 695 nm-en van egy jellegzetes töltéstranszfer sávja. Ez a 80-as metionin és az oxidált vas axiális ligandumkötéséből származik. Ez a spektrális csúcs a fehérje többi csúcsához viszonyítva jóval alacsonyabb extinkciójú, ezért csak nagy koncentrációjú fehérjeoldaton látható. Alkalikus átmeneti fázisban vagy a fehérje 
denaturálódásakor a 695 nm-es csúcs eltünik (Greenwood 1971). A metionin $80-\mathrm{Fe}^{3+}$ axiális ligandum nemcsak denaturáció esetén tünik el a spektrumból, a fehérje minimális szerkezeti változásaira is reagál. A 695 nm-es csúcs hiánya nem jelenti minden esetben a ligandum hiányát. A csúcs eltünhet akkor is, ha a 80-as metionin pozíciója a hem síkjához képest kissé megváltozik (Ångström 1982), de úgyszintén, ha a hem zseb kisebb konformációs változást szenved (Spilotros 2010).

A hem zseb nagymértékü szerkezetváltozása jelentős autoxidációs sebességnövekedéssel is járna. Szerkezetváltozást idéz elő pl. az extrém savas vagy alkalikus környezet, a különböző (poli)anionokkal való kölcsönhatás vagy a fehérje polimerizációja is (Margoliash 1962, Margoliash 1966, Harrington 1985). A nem-enzimatikusan érö citokróm $c$ autoxidációja nem mutatott lényeges különbséget az autentikus vagy az enzimatikusan érő citokróm $c$ autoxidációjához képest. A dimerizáció vagy a polimerizáció lehetőségét is kizárhatjuk, mivel a COX enzim lényegesebb aktivitásváltozást mutatna a polimerizálódott citokrómmal kölcsönhatva (Margoliash 1962), mint amit kísérleteinkben mértünk.

Egy hemtartalmú fehérje redoxpotenciálját a hem mikrokörnyezetének nagyon finom változásai befolyásolni tudják. A hem prosztetikus csoport képes összehangoltan változtatni a redox és a protonáltsági állapotát, amely tulajdonság alkalmassá teszi őt arra, hogy vele fehérjéknek a középponti redoxpotenciálját finoman „hangolni” lehessen. A beállítást a hem közvetlen környezetének változtatásával (föleg elektrosztatikus kölcsönhatásoknak köszönhetően) tudják a különböző fehérjék megoldani (Voigt 2003). Nagymértékben befolyásolja a redoxpotenciált az, hogy mennyire hozzáférhető a hem gyürüje és a propionát-oldalláncai az oldószer számára, illetve hogy mennyire rejtettek ezek a fehérje belsejében. Különösen a közelben levő ionizálható-csoportok hatása befolyásolja ezt a propionátok pK változása révén (ló szívizom citokróm $c$ esetében az Arg 38 példa erre, Das 1998). A hem axiális ligandumainak típusa is befolyásolja a redoxpotenciált.

A nem-enzimatikusan érő citokróm $c$ redoxpotenciálja valamivel alacsonyabb az autentikus és a rekombináns fehérjék redoxpotenciáljánál. Ez a relatív stabilitása az oxidált vasnak $\left(\mathrm{Fe}^{3+}\right)$ valószínűleg a vas és a 80 -as metionin axiális ligandum közötti kölcsönhatás csekély változásának a következménye. Az axiális ligandum enyhe pozícióváltozása, és az ennek hatására bekövetkező ligandumkötés-változás az oxidált abszorpciós spektrumban már nyomot hagy. A koordináció teljes megszünése viszont jóval nagyobb negatív redoxpotenciál-változást eredményezett volna, mint amekkorát mértünk.

A $c$ típusú citokrómokban a hem gyürüjének síkja nagymértékben torzult. A hem geometriájára a vas proximális koordinátora, a 18-as hisztidin különösen érzékeny. Kisebb 
változások a hem geometriájában spektrális és redoxpotenciálbeli változásokat eredményeznek (Bowman 2008). A nem-enzimatikusan érő citokróm $c$ redoxpotenciáleltolódásának okai között lehet a hem zseb polaritásának megváltozása és a hem elektromos perturbációja is.

Az alacsonyabb redoxpotenciál azt jelenti, hogy a citokróm $c$ és a COX első redox centruma, a $\mathrm{Cu}_{\mathrm{A}}$ közötti elektrontranszfer felgyorsulhat. A Marcus elmélet értelmében ugyanis, amennyiben az elektrontranszfer folyamat a normál régióba esik (és ez a helyzet a citokróm $c$ és $\mathrm{Cu}_{\mathrm{A}}$ közötti elektrontranszfer esetében), akkor a megnövekedett hajtóerő megnövekedett elektrontranszfer sebességet is jelenthet, ha egyébként más paraméterek változatlanok maradtak. A különböző citokróm $c$ fehérjék COX-szal megmért aktivitását az oxigén fogyásával követtük nyomon, aminek nincs közvetlen kapcsolata az elektrontranszfer útvonal első lépésének (ez a citokróm $c$ hemje és a $\mathrm{COX} \mathrm{Cu}_{\mathrm{A}}$-atomja közötti szakasz) sebesség-növekedésével. Mindazonáltal a COX enzim maximális turnover sebessége a nem-enzimatikusan érő citokróm $c$ esetében, ugyan nem szignifikánsan, de valamivel nagyobb volt az autentikus citokrómmal kapott értéknél. A citokróm $c$-nek COXszal való komplexképző képességéről árulkodó $K_{m}$ érték jóval érezhetőbb eltérést mutatott, amelyet a nem-enzimatikusan érő citokróm $c$-nek az autentikushoz és a rekombinánshoz viszonyított szerkezeti változásai befolyásolnak.

A nem-enzimatikusan érő citokróm $c$ spektrális és fizikai-kémiai paraméterei alapján a fehérje nem szenvedett lényeges szerkezeti változást. Összehasonlítva az autentikus és a rekombináns fehérjék paramétereivel azt mondhatjuk, hogy a hem közvetlen környezetének a minimális megváltozásáról lehet csak szó.

A fenti bizonyítékok szerint a hem kovalens kötésének reakciója végbemehet enzim közremüködése nélkül is. Az $E$. coli citoplazmájában a ló citokróm $c$ nem-enzimatikus reakcióval képes érni, lényegesen gyengébb hatásfokkal ugyan, és enyhe spektrális és fizikai-kémiai eltéréseket mutatva az autentikus és a rekombináns citokróm $c$-hez képest (Tenger 2010). A hem zseb szerkezeti változásai különösen a vas és a 80-as metionin axiális ligandumkötését érinti. Az eredményeink alapján mondhatjuk, hogy egy eukarióta citokróm $c$ is képes enzimatikus segítség nélkül funkcionális fehérjévé érni, de a CCHL katalízise a magas hozam és a natív folding szempontjából nélkülözhetetlen.

A CCHL in vivo aktivitását bizonyítottuk heterológ gazdában. A CCHL-t koexpresszálva az E. coli citoplazmájában képes nagy hozammal (4 - 5 mg/1g nedves sejt) holocitokróm $c$-t érlelni. Az érés molekuláris mechanizmusának vizsgálatát lehetővé tevő in vitro kísérlethez és a CCHL jellemzéséhez az enzimet rekombináns módon túltermeltettük 
és sikeresen kitisztítottuk. A kedvező hozam érdekében kidolgoztunk egy túltermelési és tisztítási procedúrát. $30{ }^{0} \mathrm{C}$-on, $1 \mathrm{mM}$ IPTG-vel indukálva, rövid expressziós idő alatt, a CCHL hozama $\sim 0,25 \mathrm{mg} / 1 \mathrm{~g}$ nedves sejt. A His 6 peptiddel fuzionált CCHL-t affinitáskromatográfiával megtisztítottuk és tisztaságát denaturáló poliakrilamid gélelektroforézissel bizonyítottuk. Megmértük a tiszta CCHL UV és látható tartományú abszorpciós spektrumát. Az UV tartomány alapján számoltuk a spektroszkópiai és in vitro mérésekben felhasznált fehérjeoldatok koncentrációját. A látható tartományban nem tapasztaltunk abszorpciót, tehát a CCHL önmagában nem tartalmaz kromofór-csoportot.

Megvizsgáltuk a CCHL elsődleges szekvenciáját másodlagos szerkezeti elemeket prediktáló programok (IUPred, DisProt) segítségével. Ezen vizsgálatok szerint a fehérje Nterminálisának jelentős hosszúságú összefüggő része (a 16 - 80 szakasz nagy bizonyossággal) rendezetlen szerkezetü szakasz, amely tartalmazza az irodalomból ismert két hemszabályozó CPV motívumot. További, határesetnek számító szakaszok csatlakoznak ehhez a doménhez, mielőtt a szerkezet-predikció határozottan szerkezettel rendelkező szakaszhoz ér.

Megmértük a fehérje UV CD spektrumát. A CD spektrumának illesztéséből megbecsülhető az $\alpha$-hélixek és a $\beta$-lemezek száma. Sreerama és mtsi. (1999) szerint ugyanis az $\alpha$-hélixek végein tipikusan 2 (azaz hélixenként 4), a $\beta$-lemezek végein tipikusan 1 (azaz lemezenként 2) aminosav járul hozzá a szabálytalan, torzult (ún. „distorted”) CD spektrumkomponenshez. Ennek megfelelöen, ha $\mathrm{N}_{\mathrm{res}}$ az aminosavak száma (269+6His=275), $\mathrm{f}_{\alpha \mathrm{D}}$ $\left(0,122\right.$, ld. 3. táblázat) a szabálytalan $\alpha$-hélix aránya, akkor $N_{r e s} \times f_{\alpha D}$ aminosav van ilyen pozícióban a hélixek végein, és ennek negyede, $\mathrm{N}_{\text {res }} \times \mathrm{f}_{\alpha \mathrm{D}} / 4 \mathrm{db}$. $\alpha$-hélix jósolható a fehérjében. Hasonlóan, a $\beta$-lemezek várható száma $\mathrm{N}_{\text {res }} \times \mathrm{f}_{\beta \mathrm{D}} / 2$. A 3. táblázat adatai alapján tehát az UV CD spektrumból az valószínűsíthető, hogy a CCHL fehérje - annak szerkezettel rendelkező része $-8 \alpha$-hélixet és $12 \beta$-lemezt tartalmaz. Ezek között a szerkezeti elemek között persze lehetnek annyira rövidek is, hogy nem is tartalmaznak szabályos helyzetü aminosavakat. A Sreerama és mtsi. (1999) vizsgálataiban szereplő 29, ismert röntgendiffrakciós szerkezetű és ismert UV CD spektrumú fehérje közül az a 7, melyeknek aminosavlánca a CCHL-hez hasonló hosszúságú, átlagosan $10 \alpha$-hélixet és $10 \beta$-lemezt tartalmaz, ugyanakkor ezekben az értékekben jelentős varianciát mutatnak. A CCHL rendezett doménjére kapott fenti értékek tehát szokványosnak mondhatók.

A CCHL rendezetlen és másodlagos szerkezettel rendelkező szakaszainak aminosavösszetételét is összehasonlítottuk, és azt találtuk, hogy bizonyos aminosavak jól megkülönböztethető megoszlást mutatnak a kétféle szerkezetű szakasz között, összhangban 
a rendezetlen szerkezetü fehérjék (IDP) statisztikai adataival. Megállapításainkat alátámasztja az az indirekt kísérleti eredmény is, amelyben tripszines emésztés hatására a CCHL egy 21 kDa emésztési fragmentumot adott (Steiner 1996). A fehérjék rendezetlen szerkezetű szakaszai jobban ki vannak téve a proteolitikus emésztésnek, mint a másodlagos szerkezettel rendelkező részeik, így képződhetett a $21 \mathrm{kDa}-\mathrm{os}$ CCHL fragmentum az $\mathrm{N}$ terminális vég gyorsabb emészthetőségének köszönhetően. A maradék 21 kDa-os fragmentumot a tripszin denaturáció után tudta csak továbbemészteni, ami szintén összhangban állhat azzal az állítással, hogy ez a szakasz a CCHL egy másodlagos szerkezettel rendelkező doménje.

A (részben vagy teljesen) rendezetlen, azaz IDP fehérjék általában ellenállnak a kristályosítási törekvéseknek. Ennek oka az, hogy fehérjekristályok növekedéséhez jól meghatározott ismétlődő elemi cellák összeállása szükséges, és erre kicsi az esély akkor, ha a résztvevő fehérje szerkezete nem jól definiált. Ezért azt feltételezzük, hogy a CCHL szerkezetének felderítésére nagyobb esély lesz NMR módszerrel, mint röntgenkrisztallográfiával, feltéve, hogy sikerül elegendő mennyiségü tiszta fehérjét elöállítani.

Megvizsgáltuk a tisztított CCHL és a hem kölcsönhatását. A CCHL és a hem kölcsönhatásának abszorpciós változásai magyarázatot adnak számunkra az IUPred programmal végzett szerkezet-predikciós és az irodalomból ismert proteolitikus eredményekre. Az abszorpció-változásnak két lépése van, az első lépésben az enzim kölcsönhatásba lép a szubsztráttal, a második lépésben kialakul egy hatszorosan koordinált hem spektrum. Ezt a kétlépéses folyamatot azzal magyarázzuk, hogy előbb a fehérje rendezetlen szerkezetü szakasza lép kölcsönhatásba a hemmel, ebben a lépésben a szabad hem fogyását követhettük spektrálisan, majd a második fázisban valószínü, hogy a hemszabályozó CPV motívumoknak a segítségével kialakul a hem és az enzim között egy stabilabb kölcsönhatás, amelyben a motívum cisztein oldalláncai koordinálják a vasat. Ez lehet a kísérleti bizonyítéka a Steiner és mtsi. (1996) által felvetett elméleti modellnek, miszerint az N-terminális részt egy flexibilis karnak vélik, amely a fehérje aktív centrumába „szállítja” a hemet.

In vitro holocitokróm $c$ érési kísérleteket végeztünk a tiszta CCHL-lel és az apocitokróm $c$-vel. Ezzel az in vitro kísérlettel, erős redukáló körülmények között, sikerült rekonstituálni az enzimatikus citokróm $c$ érést, amelyet spektrálisan és denaturáló gélben detektált hem kemilumineszcenciás jellel is igazoltunk.

A rekombináns citokróm $c$ mutánsok előállításának, a folyamat optimalizálásának 
eredeti célja fehérje elektrontranszfer mérésekhez jelölhető citokrómok készítése volt. Az ezeken végzett elektrontranszfer-kinetikai kísérletek megmutatták, hogy a TUPS jelölővel mérhető elektrontranszfer folyamatok a vártnál bonyolultabb, multi-exponenciális kinetikát szolgáltatnak. Ezt a jelenséget a TUPS fehérjéhez viszonyított helyzetének a heterogenitásával tudtuk magyarázni. Ez a heterogenitás egyfelől megnehezíti a jelölő és a hem közötti fehérjemátrix szerkezete és az elektrontranszfer hatékonysága közötti összefüggések kísérleti vizsgálatát. Másfelöl viszont bizonyítékot szolgáltatott arra, hogy térbeli ugrásoknak valóban szerepe lehet az optimális elektrontranszfer útvonalak kialakításában, tehát a folytonos kovalens összeköttetés donor és akceptor között egy fehérje belsejében nem jelenti feltétlenül az ideális, és ezért a valóságban megvalósuló elektrontranszfer útvonalat. Ugyanakkor a rekombináns mutáns citokróm $c$ előállításának optimalizálása lehetőséget teremt arra is, hogy a jövőben a citokróm c (és a CCHL) irányított mutagenezisével vizsgálni tudjuk a citokróm $c$ érésének molekuláris mechanizmusát. 


\section{Köszönetnyilvánítás}

Elsősorban köszönettel tartozom Dr. Zimányi Lászlónak, mint témavezetőnek az évek során nyújtott szakmai segítségéért, támogatásáért és bátorításáért.

Hálás köszönettel tartozom Dr. Rákhely Gábornak és csoportjának a lehetőségért, hogy a molekuláris biológiai, fehérje analitikai kísérleteket az SZTE Biotechnológiai Tanszékén elvégezhettem, köszönöm nekik, hogy legjobb tudásukkal segítségemre voltak a munkám során. Köszönetemet fejezem ki Dr. Rákhely Gábornak szakmai tanácsaiért és támogatásáért.

Köszönetemet fejezem ki Petro Khoroshyynak, fiatal kollégámnak, a CD, a redoxpotenciál és az aktivitás mérési kísérletek elvégzésében nyújtott segítségéért.

Dr. Bérczi Alajosnak köszönetemet fejezem ki azért, hogy az FPLC (Pharmacia) készüléket és egyéb laboreszközöket a fehérjetisztítási munkámhoz használhattam. Köszönöm szíves segítségét és szakmai tanácsait.

Köszönetet mondok Dr. Bagyinka Csabának az in vitro mérések elvégzéséhez nyújtott segítségéért.

Köszönetemet fejezem ki Dr. Carsten Sandersnek, hogy rendelkezésemre bocsájtotta a hisztidin peptiddel fuzionált CCHL génjét tartalmazó plazmidot, a citokróm $c$ maturációban mutáns EC06 E. coli törzset és köszönetemet szeretném kifejezni nagylelkü szakmai tanácsaiért, támogatásáért.

Köszönet illeti Dr. Garab Győzőt és csoportját az SzBK Növénybiológiai Intézetéből, hogy a CD méréseket lehetővé tették.

Köszönetemet fejezem ki azért, hogy az Aarhusban müködő ISA szinkrotron központban CD spektrumokat mérhettünk.

Köszönöm a Dr. Ormos Pál vezette Biofizikai Intézetnek a munkámhoz szükséges feltételek biztosítását és az intézeti munkatársak támogatását.

Végül, de nem utolsósorban hálás köszönetem családomnak, különösen szüleimnek, akik tanulmányaimat lehetővé tették, biztattak és szellemi támogatást nyújtottak. Különös köszönettel tartozom élettársamnak, Kiss Károlynak, akinek türelme és rendkívüli szellemi támogatása felbecsülhetetlen segítséget nyújtott számomra. 


\section{Irodalomjegyzék}

Alberts B, Johnson A, Lewis J, Raff M, Roberts K, Walter P. Molecular Biology of the Cell, Chapter 14: Energy Conversion: Mitochondria and Chloroplasts, $5^{\text {th }}$ edition, 2008., Garland Science, N. Y.

Allen JW, Daltrop O, Stevens JM, Ferguson SJ. 2003a. C-type cytochromes: diverse structures and biogenesis systems pose evolutionary problems. Philos. Trans. R. Soc. Lond. B. Biol. Sci. 358(1429):255-266.

Allen J W, Barker PD, Ferguson SJ. 2003b. A cytochrome $b_{562}$ variant with a $c$-type cytochrome $\mathrm{CXXCH}$ heme-binding motif as a probe of the Escherichia coli cytochrome $c$ maturation system. J. Biol. Chem. 278:52075-52083.

Allen JW, Ginger ML, Ferguson SJ. 2004. Maturation of the unusual single-cysteine $(\mathrm{XXXCH})$ mitochondrial $c$-type cytochromes found in trypanosomatids must occur through a novel biogenesis pathway. Biochem. J. 383:537-542.

Allen JW, Leach N, Ferguson SJ. 2005a. The histidine of the $c$-type cytochrome CXXCH haem-binding motif is essential for haem attachment by the Escherichia coli cytochrome $c$ maturation (Ccm) apparatus. Biochem. J. 389(Pt 2):587-592.

Allen JW, Barker PD, Daltrop O, Stevens JM, Tomlinson EJ, Sinha N, Sambongi Y, Ferguson SJ. 2005b. Why isn't 'standard' heme good enough for $c$-type and $d_{1}$-type cytochromes? Dalton. Trans. 2005: 3410-3418.

Allen JW, Ferguson SJ. 2006. What is the substrate specificity of the System I cytochrome $c$ biogenesis apparatus? Biochem. Soc. Trans. 34:150-151.

Allen JW, Harvat EM, Stevens JM, Ferguson SJ. 2006. A variant System I for cytochrome $c$ biogenesis in archaea and some bacteria has a novel CcmE and no CcmH. FEBS Lett. 580:4827-4834.

Allen JW, Jackson AP, Rigden DJ, Willis AC, Ferguson SJ, Ginger ML. 2008. Order within a mosaic distribution of mitochondrial c-type cytochrome biogenesis systems? FEBS J. 275:2385-2402.

Allen JW, Sawyer EB, Ginger ML, Barker PD, Ferguson SJ. 2009. Variant $c$-type cytochromes as probes of the substrate specificity of the E. coli cytochrome $c$ maturation (Ccm) apparatus. Biochem. J. 419(1):177-184, 2 p following 184.

Ambler RP, Wynn M. 1973. The amino acid sequences of cytochromes $c_{551}$ from three species of Pseudomonas. Biochem. J. 131(3):485-498.

Ambler RP. 1991. Sequence variability in bacterial cytochromes $c$. Biochim. Biophys. Acta. 
1058(1):42-47.

Ångström J, Moore G.R, Williams RJP. 1982. The magnetic susceptibility of ferricytochrome- $c$. Biochim. Biophys. Acta. 703, 87-94.

Arnesano F, Banci L, Bertini I, Ciofi-Baffoni S, Woodyear TL, Johnson CM, Barker PD. 2000. Structural consequences of $b$ - to $c$-type heme conversion in oxidized Escherichia coli cytochrome $b_{562}$. Biochemistry. 39:1499-1514.

Ausubel FM, Brent R, Kingston RE, Moore DD, Seidman JG, Smith JA, Struhl K. 1996. Current protocols in molecular biology. V. B. Chanda (ed.), Wiley, N. Y.

Barker PD, Ferrer JC, Mylrajan M, Loehr TM, Feng R, Konishi Y, Funk WD, MacGillivray RT, Mauk AG. 1993. Transmutation of a heme protein. Proc. Natl. Acad. Sci. USA 90:6542-6546.

Barker PD, Nerou EP, Freund SM, Fearnley IM. 1995. Conversion of cytochrome $b_{562}$ to $c$ type cytochromes. Biochemistry. 34: 15191-15203.

Barker PD, Ferguson SJ. 1999. Still a puzzle: why is haem covalently attached in $c$-type cytochromes? Structure. 7: R281-R290.

Bartsch RG. 1971. Cytochromes: bacterial. Methods Enzymol. 23: 344-363.

Berg JM, Tymoczko JL, Stryer L. Biochemistry, Chapter 18: Oxidative phosphorilation. $6^{\text {th }}$ Edition, 2007. New York: W.H. Freeman, and Company.

Bernard DG, Gabilly ST, Dujardin G, Merchant S, Hamel PP. 2003. Overlapping specificities of the mitochondrial cytochrome $c$ and $c_{1}$ heme lyases. J. Biol. Chem. 278:49732-49742.

Bernard DG, Quevillon-Cheruel S, Merchant S, Guiard B, Hamel PP. 2005. Cyc2p, a membrane-bound flavoprotein involved in the maturation of mitochondrial $c$-type cytochromes. J. Biol. Chem. 280(48):39852-39859.

Borgia A, Gianni S, Brunori M, Travaglini-Allocatelli C. 2008. Fast folding kinetics and stabilization of apo-cytochrome $c$. FEBS Lett. 582(6):1003-1007.

Bowman SE, Bren KL. 2008. The chemistry and biochemistry of heme $c$ : functional bases for covalent attachment. Nat. Prod. Rep. 25:1118-1130, Review.

Cantor CR, Schimmel PR. 1980. Biophysical Chemistry II. W.H. Freeman and Co., p 377.

Choe M, Reznikoff WS. 1993. Identification of the regulatory sequence of anaerobically expressed locus aeg-46.5. J. Bacteriol. 175(4):1165-1172.

Christensen O, Harvat EM, Thöny-Meyer L, Ferguson SJ, Stevens JM. 2007. Loss of ATP hydrolysis activity by $\mathrm{CcmAB}$ results in loss of $c$-type cytochrome synthesis and incomplete processing of CcmE. FEBS J. 274(9):2322-2332. 
Cohen JS, Fisher WR, Schechter AN. 1974. Spectroscopic studies on the conformation of cytochrome $c$ and apocytochrome $c$. J. Biol. Chem. 249(4):1113-1118.

Craig DB, Nichols ER. 2006. Spectroscopic measurement of the redox potential of cytochrome $c$ for the undergraduate biochemistry laboratory. J. Chem. Educ. 83(9):1325-1326.

Daltrop O, Allen JW, Willis AC, Ferguson SJ. 2002. In vitro formation of a $c$-type cytochrome. Proc. Natl. Acad. Sci. USA 99:7872-7876.

Daltrop O, Smith KM, Ferguson SJ. 2003a. Stereoselective in vitro formation of $c$-type cytochrome variants from Hydrogenobacter thermophilus containing only a single thioether bond. J. Biol. Chem. 278:24308-24313.

Daltrop O, Ferguson SJ. 2003b. Cytochrome $c$ maturation. The in vitro reactions of horse heart apocytochrome $c$ and Paracoccus dentrificans apocytochrome $c_{550}$ with heme. J. Biol. Chem. 278(7):4404-4409.

Das DK, Medhi OK. 1998. The role of heme propionate in controlling the redox potential of heme: square wave voltammetry of protoporphyrinato IX iron (III) in aqueous surfactant micelles. J. Inorg. Biochem. 70(2):83-90.

Diekert K, Kispal G, Guiard B, Lill R. 1999. An internal targeting signal directing proteins into the mitochondrial intermembrane space. Proc. Natl. Acad. Sci. USA. 12; 96(21):11752-11757.

Diekert K, de Kroon AI, Ahting U, Niggemeyer B, Neupert W, de Kruijff B, Lill R. 2001. Apocytochrome $c$ requires the TOM complex for translocation across the mitochondrial outer membrane. EMBO J. 20(20):5626-5635.

Dolgikh DA, Latypov RF, Abdullaev ZKh, Kolov V, Roder H, Kirpichnikov MP. 1998. Expression of mutant horse cytochrome $c$ genes in Escherichia coli. Bioorg. Khim. 24(10):756-759.

Dumont ME, Richards FM. 1984. Insertion of apocytochrome $c$ into lipid vesicles. J. Biol. Chem. 259(7):4147-4156.

Dumont ME, Ernst JF, Hampsey DM, Sherman F. 1987. Identification and sequence of the gene encoding cytochrome $c$ heme lyase in the yeast Saccharomyces cerevisiae. EMBO J. 6:235-241.

Dumont ME, Ernst JF, Sherman F. 1988. Coupling of heme attachment to import of cytochrome $c$ into yeast mitochondria: Studies with heme lyase-deficient mitochondria and altered apocytochromes $c$. J. Biol. Chem. 263, 15928-15937.

Dumont MD, Mathews AJ, Nall BT, Baim SB, Eustice DC, Sherman F. 1990. Differential 
stability of two apo-iso-cytochromes $c$ in the yeast Saccharomyces cerevisiae. J. Biol. Chem. 265(5):2733-2739.

Dumont ME, Cardillo TS, Hayes MK, Sherman F. 1991. Role of cytochrome $c$ heme lyase in mitochondrial import and accumulation of cytochrome $c$ in Saccharomyces cerevisiae. Mol. Cell. Biol. 11(11):5487-5496.

Dumont ME, Corin AF, Campbell GA. 1994. Noncovalent binding of heme induces a compact apocytochrome $c$ structure. Biochemistry. 33(23):7368-7378.

Dumont ME. 1996. Mitochondrial import of cytochrome $c$. in: F.-U. Hart (Ed.), Advances in Molecular and Cell Biology, JAI Press, Greenwich, UK, pp. 103-126.

Eaves DJ, Grove J, Staudenmann W, James P, Poole RK, White SA, Griffiths I, Cole JA. 1998. Involvement of products of the nrfEFG genes in the covalent attachment of haem $c$ to a novel cysteine-lysine motif in the cytochrome $c_{552}$ nitrite reductase from Escherichia coli. Mol. Microbiol. 28:205-216.

El Kirat K, Morandat S. 2009. Cytochrome $c$ interaction with neutral lipid membranes: influence of lipid packing and protein charges. Chem. Phys. Lipids. 162(1-2):17-24.

Enosawa S, Ohashi A. 1986. Localization of enzyme for heme attachment to apocytochrome $c$ in yeast mitochondria. Biochem. Biophys. Res. Commun. 141(3):1145-1150.

Feissner RE, Richard-Fogal CL, Frawley ER, Kranz RG. 2006a. ABC transporter-mediated release of a haem chaperone allows cytochrome $c$ biogenesis. Mol. Microbiol. 61(1):219-231.

Feissner RE, Richard-Fogal CL, Frawley ER, Loughman JA, Earley KW, Kranz RG. 2006b. Recombinant cytochromes $c$ biogenesis systems I and II and analysis of haem delivery pathways in Escherichia coli. Mol. Microbiol. 60(3):563-577.

Ferguson SJ. 2001. Keilin's cytochromes: how bacteria use them, vary them and make them. Biochem. Soc. Trans. 29(Pt 6):629-640.

Ferguson SJ, Stevens JM, Allen JW, Robertson IB. 2008. Cytochrome $c$ assembly: a tale of ever increasing variation and mystery? Biochim. Biophys. Acta. 1777(7-8):980-984. Review.

Fisher WR, Taniuchi H, Anfinsen CB. 1973. On the role of heme in the formation of the structure of cytochrome $c$. J. Biol. Chem. 248(9):3188-3195.

Fülöp V, Sam KA, Ferguson SJ, Ginger ML, Allen JW. 2009. Structure of a trypanosomatid mitochondrial cytochrome $c$ with heme attached via only one thioether bond and implications for the substrate recognition requirements of heme lyase. FEBS J. 
276:2822-2832. Review.

Giegé P, Grienenberger JM, Bonnard G. 2008. Cytochrome $c$ biogenesis in mitochondria. Mitochondrion. 8 (1):61-73.

Greenwood C, Wilson MT. 1971. Studies on ferricytochrome c. I. Effect of pH, ionic strength and protein denaturants on the spectra of ferricytochrome $c$. Eur. J. Biochem. 22(1):5-10.

Guzman LM, Belin D, Carson MJ, Beckwith J. 1995. Tight regulation, modulation, and high-level expression by vectors containing the arabinose $\mathrm{P}_{\mathrm{BAD}}$ promoter. $\mathrm{J}$. Bacteriol. 177(14):4121-4130.

Hamel P, Corvest V, Giege P, Bonnard G. 2008. Biochemical requirements for the maturation of mitochondrial $c$-type cytochromes. Biochim. Biophys. Acta 1793:125138. Review.

Hakvoort TB, Sprinkle JR, Margoliash E. 1990. Reversible import of apocytochrome $c$ into mitochondria. Proc. Natl. Acad. Sci. USA. 87(13):4996-5000.

Harrington JP, Carrier TL. 1985. Influence of several perturbants on the rate of autoxidation of horse heart ferrocytochrome $c$. Int. J. Biochem. 17(1):119-122.

Hartshorne RS, Kern M, Meyer B, Clarke TA, Karas M, Richardson DJ, Simon J. 2007. A dedicated haem lyase is required for the maturation of a novel bacterial cytochrome $c$ with unconventional covalent haem binding. Mol. Microbiol. 64:1049-1060.

Ho SN, Hunt HD, Horton RM, Pullen JK, Pease LR. 1989. Site-directed mutagenesis by overlap extension using the polymerase chain reaction. Gene. 77(1):51-59.

Inoue H, Nojima H, Okayama H. 1990. High efficiency transformation of Escherichia coli with plasmids. Gene. 30; 96(1):23-28.

King TE. 1967. The keilin-hartree heart muscle preparation, Methods Enzymol., Oxidation and Phosphorylation, Academic Press, pp. 202-208.

Kotlyar AB, Borovok N, Hazani M. 1997a. Use of thiouredopyrenetrisulfonate photochemistry for driving electron transfer reactions in aqueous solutions. Biochemistry. 36(50):15823-15827.

Kotlyar AB, Borovok N, Hazani M. 1997b. Photoinduced electron transfer in singly labeled thiouredopyrenetrisulfonate cytochrome $c$ derivatives. Biochemistry. 36(50):1582815833.

Kotlyar AB, Borovok N, Khoroshyy P, Tenger K, Zimányi L. 2004. Redox photochemistry of thiouredopyrenetrisulfonate. Photochem. Photobiol. 79(6):489-493.

Kranz R, Lill R, Goldman B, Bonnard G, Merchant S. 1998. Molecular mechanisms of 
cytochrome $c$ biogenesis: three distinct systems. Mol. Microbiol. 29(2):383-396. Review.

Kranz RG, Richard-Fogal C, Taylor JS, Frawley ER. 2009. Cytochrome $c$ biogenesis: mechanisms for covalent modifications and trafficking of heme and for heme-iron redox control. Microbiol. Mol. Biol. Rev. 73(3):510-528. Review.

Kuras R, de Vitry C, Choquet Y, Girard-Bascou J, Culler D, Büschlen S, Merchant S, Wollman FA. 1997. Molecular genetic identification of a pathway for heme binding to cytochrome $b_{6}$. J. Biol. Chem. 272(51):32427-32435.

Kuras R, Saint-Marcoux D, Wollman FA, de Vitry C. 2007. A specific c-type cytochrome maturation system is required for oxygenic photosynthesis. Proc. Natl. Acad. Sci. USA 104:9906-9910.

Kurisu G, Zhang H, Smith JL, Cramer WA. 2003. Structure of the cytochrome $b_{6} f$ complex of oxygenic photosynthesis: tuning the cavity. Science. 302(5647):1009-1014.

Lee D, Pervushin K, Bischof D, Braun M, Thöny-Meyer L. 2005. Unusual heme-histidine bond in the active site of a chaperone. J. Am. Chem. Soc. 23;127(11):3716-3717.

Lees JG, Smith BR, Wien F, Miles AJ, Wallace BA. 2004. CDtool-an integrated software package for circular dichroism spectroscopic data processing, analysis, and archiving. Anal. Biochem. 332(2):285-289.

Levantino M, Huang Q, Cupane A, Laberge M, Hagarman A, Schweitzer-Stenner R. 2005. The importance of vibronic perturbations in ferrocytochrome $c$ spectra: a reevaluation of spectral properties based on low-temperature optical absorption, resonance Raman, and molecular-dynamics simulations. J. Chem. Phys. 123(5):054508-12.

Lill R, Stuart RA, Drygas ME, Nargang FE, Neupert W. 1992. Import of cytochrome $c$ heme lyase into mitochondria: a novel pathway into the intermembrane space. EMBO J. 11(2):449-456.

Lyska D, Paradies S, Meierhoff K, Westhoff P. 2007. HCF208, a homolog of Chlamydomonas $\mathrm{CCB} 2$, is required for accumulation of native cytochrome $b_{6}$ in Arabidopsis thaliana. Plant. Cell. Physiol. 48(12):1737-1746.

Margoliash E, Lustgarten J. 1962. Interconversion of horse heart cytochrome $c$ monomer and polymers. J. Biol. Chem. 237:3397-3405.

Margoliash E, Schejter A. 1966. Cytochrome c. Adv. Protein Chem. 21:113-286.

Matner RR, Sherman F. 1982. Differential accumulation of two apo-iso-cytochromes $c$ in processing mutants of yeast. J. Biol. Chem. 257(16):9811-9821. 
Mayer A, Neupert W, Lill R. 1995. Translocation of apocytochrome $c$ across the outer membrane of mitochondria. J. Biol. Chem. 270(21):12390-12397.

Metcalfe CL, Daltrop O, Ferguson SJ, Raven EL. 2007. Tuning the formation of a covalent haem-protein link by selection of reductive or oxidative conditions as exemplified by ascorbate peroxidase. Biochem. J. 408:355-361.

Moore GR, Pettigrew GW. 1990. Cytochromes c. Evolutionary, structural and physicochemical aspects. Springer-Verlag, Berlin - Heidelberg - N. Y.

Moser CC, Keske JM, Warncke K, Farid RS, Dutton PL. 1992. Nature of biological electron transfer. Nature. 355:796-802.

Nicholls DG, Ferguson SJ. 2002. Bioenergetics 3. Academic Press, 89-157.

Nicholson DW, Hergersberg C, Neupert W. 1988. Role of cytochrome $c$ heme lyase in the import of cytochrome $c$ into mitochondria. J. Biol. Chem. 263(35):19034-19042.

Nicholson DW, Neupert W. 1989. Import of cytochrome $c$ into mitochondria: reduction of heme, mediated by NADH and flavin nucleotides, is obligatory for its covalent linkage to apocytochrome $c$. Proc. Natl. Acad. Sci. USA. 86(12):4340-4344.

Ott M, Zhivotovsky B, Orrenius S. 2007. Role of cardiolipin in cytochrome $c$ release from mitochondria. Cell Death Differ. 14(7):1243-1247.

Padmanaban G, Venkateswar V, Rangarajan PN. 1989. Haem as a multifunctional regulator. Trends Biochem. Sci. 14(12):492-496. Review.

Page CC, Moser CC, Chen XX, Dutton PL. 1999. Natural engineering principles of electron tunnelling in biological oxidation-reduction. Nature. 402:47-52.

Pollock WB, Rosell FI, Twitchett MB, Dumont ME, Mauk AG. 1998. Bacterial expression of a mitochondrial cytochrome $c$. Trimethylation of lys72 in yeast iso-1-cytochrome $c$ and the alkaline conformational transition. Biochemistry. 37:6124-6131.

Rios-Velazquez C, Cox RL, Donohue TJ. 2001. Characterization of Rhodobacter sphaeroides cytochrome $c_{2}$ proteins with altered heme attachment sites. Arch. Biochem. Biophys. 389:234-244.

Rumbley JN, Hoang L, Englander SW. 2002. Recombinant equine cytochrome $c$ in Escherichia coli: high-level expression, characterization, and folding and assembly mutants. Biochemistry. 41(47):13894-13901.

Sambrook J, Maniatis T, Fritsch EF. 1989. Molecular Cloning: A Laboratory Manual. Cold Spring Harbor Laboratory Press, Cold Spring Harbor, N.Y.

Sanbongi Y, Yang JH, Igarashi Y, Kodama T. 1991. Cloning, nucleotide sequence and expression of the cytochrome $c_{552}$ gene from Hydrogenobacter thermophilus. Eur. J. 
Biochem. 198(1):7-12.

Sanders C, Lill H. 2000. Expression of prokaryotic and eukaryotic cytochromes $c$ in Escherichia coli. Biochim. Biophys. Acta. 1459(1):131-138.

Sanders C, Turkarslan S, Lee DW, Daldal F. 2010. Cytochrome $c$ biogenesis: the Ccm system. Trends Microbiol. 18(6):266-74. Review.

Schleif R. 2000. Regulation of the L-arabinose operon of Escherichia coli. Trends Genet. 16(12):559-65.

Schulz H, Hennecke H, Thöny-Meyer L. 1998. Prototype of a heme chaperone essential for cytochrome $c$ maturation. Science. 281(5380):1197-1200.

Schweitzer-Stenner R, Levantino M, Cupane A, Wallace C, Laberge M, Huang Q. 2006. Functionally relevant electric-field induced perturbations of the prosthetic group of yeast ferrocytochrome $c$ mutants obtained from a vibronic analysis of lowtemperature absorption spectra. J. Phys. Chem. B. 110(24):12155-12161.

Sickmeier M, Hamilton JA, LeGall T, Vacic V, Cortese MS, Tantos A, Szabo B, Tompa P, Chen J, Uversky VN, Obradovic Z, Dunker AK. 2007. DisProt: the database of disordered proteins. Nucleic Acids Res. 35 (Database issue):D786-793.

Sinha N, Ferguson SJ. 1998. An Escherichia coli ccm (cytochrome $c$ maturation) deletion strain substantially expresses Hydrogenobacter thermophilus cytochrome $c_{552}$ in the cytoplasm: availability of haem influences cytochrome $c_{552}$ maturation. FEMS Microbiol. Lett. 161(1):1-6.

Spilotros A, Levantino M, Cupane A. 2010. Conformational substates of ferricytochrome $c$ revealed by combined optical absorption and electronic circular dichroism spectroscopy at cryogenic temperature. Biophys. Chem. 147(1-2):8-12.

Sreerama N, Venyaminov SY, Woody RW. 1999. Estimation of the number of $\alpha$-helical and $\beta$-strand segments in proteins using circular dichroism spectroscopy. Protein Science. 8:370-380.

Steiner H, Zollner A, Haid A, Neupert W, Lill R. 1995. Biogenesis of mitochondrial heme lyases in yeast. Import and folding in the intermembrane space. J. Biol. Chem. 29; 270(39):22842-22849.

Steiner H, Kispal G., Zollner A, Haid A, Neupert W, Lill R. 1996. Heme binding to a conserved Cys-Pro-Val motif is crucial for the catalytic function of mitochondrial heme lyases. J. Biol. Chem. 271:32605-32611.

Stellwagen E, Rysavy R, Babul G. 1972. The conformation of horse heart apocytochrome $c$. J. Biol. Chem. 247(24):8074-8077. 
Stevens JM, Daltrop O, Allen JW, Ferguson SJ. 2004. C-type cytochrome formation: chemical and biological enigmas. Acc. Chem. Res. 37(12):999-1007. Review.

Stroebel D, Choquet Y, Popot JL, Picot D. 2003. An atypical haem in the cytochrome $b_{6} f$ complex. Nature. 426(6965):413-418.

Stuart RA, Neupert W. 1990a. Apocytochrome $c$ : an exceptional mitochondrial precursor protein using an exceptional import pathway. Biochimie. 72(2-3):115-121. Review.

Stuart RA, Nicholson DW, Neupert W. 1990b. Early steps in mitochondrial protein import: receptor functions can be substituted by the membrane insertion activity of apocytochrome $c$. Cell. 60(1):31-43.

Tenger K, Khoroshyy P, Leitgeb B, Rákhely G, Borovok N, Kotlyar A, Dolgikh DA, Zimányi L. 2005. Complex kinetics of the electron transfer between the photoactive redox label TUPS and the heme of cytochrome $c$. J. Chem. Inf. Model. 45(6):15201526.

Tenger K, Khoroshyy P, Kovács KL, Zimányi L, Rákhely G. 2007. Improved system for heterologous expression of cytochrome $c$ mutants in Escherichia coli. Acta Biol. Hung.; 58 Suppl:23-35.

Tenger K, Khoroshyy P, Rákhely G, Zimányi L. 2010. Maturation of a eukaryotic cytochrome $c$ in the cytoplasm of Escherichia coli without the assistance by a dedicated biogenesis apparatus. J. Bioenerg. Biomembr. 42(2):125-133.

Thöny-Meyer L, Fischer F, Künzler P, Ritz D, Hennecke H. 1995. Escherichia coli genes required for cytochrome $c$ maturation. J. Bacteriol. 177(15):4321-4326.

Thöny-Meyer L. 1997. Biogenesis of respiratory cytochromes in bacteria. Microbiol. Mol. Biol. Rev. 61(3):337-376. Review.

Thöny-Meyer L. 2002. Cytochrome $c$ maturation: a complex pathway for a simple task? Biochem. Soc. Trans. 30(4):633-638.

Tomlinson EJ, Ferguson SJ. 2000a. Conversion of a $c$-type cytochrome to a $b$ type that spontaneously forms in vitro from apo protein and heme: implications for $c$ type cytochrome biogenesis and folding. Proc. Natl. Acad. Sci. USA. 97(10):5156-5160.

Tomlinson EJ, Ferguson SJ. 2000b. Loss of either of the two heme-binding cysteines from a class I $c$-type cytochrome has a surprisingly small effect on physicochemical properties. J. Biol. Chem. 275(42):32530-32534.

Tompa P. 2002. Intrinsically unstructured proteins. Trends Biochem. Sci. 27(10):527-533. Review.

Tompa P. 2009. Rendezetlen fehérjék, amelyek új megvilágításba helyezik a szerkezet- 
funkció-összefüggést. Magyar Tudomány. 170 évf. 7., 808-814.

Tong J, Margoliash E. 1998. Cytochrome $c$ heme lyase activity of yeast mitochondria. J. Biol. Chem. 273(40):25695-25702.

Yonetani T. 1967. Cytochrome oxidase: Beef Heart. In Methods Enzymol., Oxidation and Phosphorylation. Academic Press., pp. 332-335.

Vargas C, McEwan AG, Downie JA. 1993. Detection of $c$-type cytochromes using enhanced chemiluminescence. Anal. Biochem. 209(2):323-326.

Veloso D, Juillerat M, Taniuchi H. 1984. Synthesis of a heme fragment of horse cytochrome $c$ which forms a productive complex with a native apofragment. J. Biol. Chem. 259(10):6067-6073.

Voigt P, Knapp EW. 2003. Tuning heme redox potentials in the cytochrome $c$ subunit of photosynthetic reaction centers. J. Biol. Chem. 278(52):51993-52001.

Wang X, Dumont ME, Sherman F. 1996. Sequence requirements for mitochondrial import of yeast cytochrome $c$. J. Biol. Chem. 271(12):6594-6604.

Wiedemann N, Kozjak V, Prinz T, Ryan MT, Meisinger C, Pfanner N, Truscott KN. 2003. Biogenesis of yeast mitochondrial cytochrome $c$ : a unique relationship to the TOM machinery. J. Mol. Biol. 327(2):465-474.

Winkler JR, Gray HB. 1997. Electron tunneling in proteins - role of the intervening medium. J. Biol. Inorg. Chem. 2:399-404.

Zhang L, Guarente L. 1995. Heme binds to a short sequence that serves a regulatory function in diverse proteins. EMBO J. 14(2):313-320.

Zhang M, Mileykovskaya E, Dowhan W. 2002. Gluing the respiratory chain together. Cardiolipin is required for supercomplex formation in the inner mitochondrial membrane. J. Biol. Chem. 277(46):43553-43556. 


\section{Összefoglalás}

A c típusú citokrómok olyan hemtartalmú fehérjék, amelyek hem prosztetikuscsoportjukat vagy -csoportjaikat tioéter kötésen keresztül, kovalensen kötik. Ez a kapcsolat általában a hem két vinilcsoportja és a polipeptidláncban előforduló hemkötő motívum (Cys-Xxx-Xxx-Cys-His) között alakul ki. A motívumban előforduló hisztidin egyben a hem vasának ötödik koordinátora. Az Xxx a motívumban jelölhet bármilyen aminosavat, kivéve ciszteint. A $c$ típusú citokrómokban a hem vasának van egy hatodik koordinátora is, amely a polipeptidláncban egy disztálisan elhelyezkedő metionin vagy hisztidin aminosavoldallánca. Léteznek a fenti szabálytól eltérő esetek is, mind a motívum milyenségét, mind a tioéter kötések számát illetően, de lehet változás az ötödik koordinátor tekintetében is. Van olyan eset, ahol egyetlen cisztein oldallánccal kötött a hem az egyik vinilcsoportján keresztül egy módosult hemkötő motívumhoz. A motívumokat illetően vannak olyan változatok, ahol a két ciszteint elválasztó aminosavak száma több mint kettő.

A c típusú citokrómok poszttranszlációs modifikációját érésnek nevezzük, amely természetes körülmények között egy érlelő rendszer által asszisztált folyamat. A biológiai rendszerekben különböző komplexitású modifikációs rendszerek ismertek, amelyeket általánosan három nagy csoportba sorolhatunk. Természetesen vannak kivételek is, olyanok, amelyek főleg a fent említett hemkötő motívum-változatok felismerésére specializálódtak.

A $c$ típusú citokrómok általában elektrontranszfer szerepet töltenek be különböző redoxfolyamatokban, de szerepelhetnek enzimek katalitikus központjaiként is. A mitokondriális szolubilis citokróm $c$-nek pl. fontos kaszkádindukáló szerepe is van a programozott sejthalálban.

Kísérleteinkhez a mitokondriális szolubilis citokróm $c$-t használtuk fel. Ez a fehérje az intermembrán térben, a légzési redoxlánc részeként, a belső membrán felületéhez tapadva szállít elektronokat a protongrádiens kialakításában is résztvevő membránkötött partnerei között. A hem kötését mitokondriális $c$ típusú citokrómokhoz az érési rendszerek legegyszerübbike végzi. Ezt egyetlen, az intermembrán térben elhelyezkedő szolubilis (de a belső membrán felületével szoros kölcsönhatásban levő) fehérje, a citokróm $c$ hem liáz (CCHL) vagy holocitokróm $c$ szintetáz alkotja. A CCHL-nek bizonyos szervezetekben kétféle változata is jelen lehet, attól függően, hogy a citokróm $c$-nek és a $c_{1}$-nek külön érlelő enzime van-e (példák erre a gombák), magasabbrendű szervezetek mitokondriumában (az ember esetében is) egy enzim végzi a kétféle $c$ típusú citokróm érlelését.

Munkám során a mitokondriális citokróm $c$ vad és mutáns változatait is használtuk 
elektrontranszfer kísérletekben, ill. vad változatát citokróm $c$ poszttranszlációs érési kísérletekben. Ez a kis molekulasúlyú mitokondriális redoxfehérje elektrontranszfer mérésekre jól alkalmazható az alábbi tulajdonságai miatt: szolubilis és stabil szerkezetü fehérje; vad és cisztein mutáns változatai heterológ gazdában nagy hozammal előállíthatóak; elsődleges szerkezete a két hemkötésben résztvevő ciszteinjén kívül egyéb ciszteint nem tartalmaz.

$\mathrm{Az}$ elektrontranszfer kísérletekhez a gondosan megtervezett és irányított mutagenezissel létrehozott, majd túltermeltetett cisztein mutánsokat egy arra alkalmas fotoaktív festékkel jelöltük meg. A fehérje különböző pontjaira bevitt ciszteinekkel az elektrondonor pozícióját változtattuk meg, miáltal az elektrontranszfer-útvonal hosszának a variálása vált lehetővé. Az egyes jelölöpozíciók esetén a donor és az akceptor (a hem) közötti fehérjemátrix molekuláris szerkezete is eltérő. A fotoaktív festéknek egy másik változata lizin oldalláncok jelölésére alkalmas. A vad típusú fehérjét az eredeti lizineken is megjelölve két mutánsunk (K8C és K39C) esetében is mód nyílt az elektrontranszfer hatékonyságának közvetlen összehasonlítására. A különbség a két esetben az, hogy a cisztein mutáns esetében a festék egy kovalens kötéssel hosszabb láncon kapcsolódik a fehérjéhez. Ez a különbség a lizinjelölt változat esetében megnövekedett elektrontranszfersebességet kellett volna, hogy eredményezzen, ha az elektron követi a kovalens útvonalat. A mérések eredménye szerint a különböző változatokon mért elektrontranszfer csak több időbeli exponenciális összegével illeszthetö, és nincs korreláció a donor és akceptor közötti kovalens távolság és a mért elektrontranszfer sebessége között. A kísérleti eredményeinket egy modellszámolás támasztja alá, amely szerint a flexibilis kovalens lánccal kapcsolt festék több, az elektrontranszfer időskáláján stabilnak tekinthető helyzetet is elfoglalhat a fehérje felszínén. Így a festék gyürüs része bizonyos esetekben olyan pozíciót foglalhat el, ahonnan az optimális elektrontranszfer a hem irányába nem a kovalens láncon keresztül történik, hanem egy térbeli ugrással kezdődik, és ekkor az elektron a fehérje ezen felületi atomjától halad tovább a hem irányába.

A mutánsok elóállítása érdekében kidolgoztunk egy nagy hozamot biztosító expressziós rendszert. A rendszer elvi alapjainak lerakása nem a mi érdemünk, mi létrehoztunk egy magas hozamot biztosító és megbízhatóan müködő túltermelő rendszert, amelyben megoldottuk a mutáns gén könnyü cserélhetőségét is. Ennek lényege, hogy egy fehérje-túltermelésre ideális E. coli törzsben (BL21-AI) egy szigorúan szabályozható promóterről (a pBAD24 plazmid arabinóz-indukálható $\mathrm{P}_{\mathrm{BAD}}$ promóteréről) a citokróm $c$ expressziója mellett a maturációért felelős enzimet is koexpresszáljuk. Az érés a baktérium 
citoplazmájában történik, a vad típus esetében akár 5mg/1 g nedves sejt hozammal, amelyet az első tisztítási lépés, a centrifugálás utáni felülúszó spektrumának felvételéből határoztunk meg. A sejt szolubilis frakciójából való számolást a magas hozam teszi lehetővé, ugyanis a citokróm $c$ spektruma uralja az abszorpciós spektrumot. Hasonlóan magas hozamú heterológ expressziót és citokróm $c$ érést eredményezett az a rendszer is, amelyben a citokróm $c$ és a CCHL génjét két különböző plazmid promóteréről fejeztük ki, nem sztöchiometrikus arányban. A pBAD24-es plazmiddal, amely a citokróm $c$ génjét hordozta, kotranszformáltunk egy genetikailag kompatibilis plazmidot, amelyről IPTG-vel indukáltuk a CCHL kifejeződését.

Az apocitokróm $c$ heterológ expressziója az E. coli citoplazmájában az érlelő enzim jelenléte nélkül is eredményezett holocitokróm termelést, noha jóval kisebb hozammal ( 2\%-a az enzimes hozamnak). Az így érő citokróm $c$ funkcionális fehérje, de az autentikus és az enzimmel érő citokrómokhoz képest némileg eltérő spektrummal (Soret csúcsának kettő, a csúcsának egy nanométeres vörös irányú eltolódása van) és fizikai-kémiai paraméterekkel rendelkezik. A nem-enzimatikus érést a baktérium citoplazmájában fennálló redukáló körülményeknek és az apocitokróm $c$ relatív stabilitásának tulajdonítjuk. Enzimatikus közremüködés nélkül ezek között a körülmények között a polipeptidlánc és a hem - igaz jóval kisebb arányban, mint ahogy az az érlelö enzim jelenlétében megtörténik , de olyan kölcsönhatást létesíthet, amelyben a kovalens kötést kialakító csoportok proximitásának következtében a tioéter kapcsolat spontán kialakulhat.

A nem-enzimatikusan érő citokróm $c$ kovalens hemkötését denaturáló poliakrilamid gélelektroforézist követően igazoltuk. Az ilyen körülmények között szeparált citokróm $c$ fehérjén detektáltunk kemilumineszcenciás jelet, amely a kovalensen kötött hem peroxidázaktivitásából származott. A nem-enzimatikusan érő tisztított citokróm $c$-nek meghatároztuk néhány spektrális és fizikai-kémiai paraméterét. A fehérjébe beépülő hem kovalens módosulásáról, s ezáltal a helyes kötésről is a redukált fehérje piridin hemokróm spektrumából szereztünk ismereteket. A piridin-koordinált redukált hem spektruma denaturáló körülmények között kizárólag a hemmódosulásról ad információkat. A nemkötött, a kétszeresen vagy csak egyszeresen kötött hemeknek jellegzetes $\alpha$ csúcsmaximumaik vannak. A nem-enzimatikusan érő fehérje esetében ez a spektrum a kétszeres hemkötést igazolta. A nem-enzimatikusan érő citokróm $c$ funkcionálisan aktív és az autentikus, illetve az enzimatikusan érlelt fehérjék aktivitási paramétereihez nagyon hasonló értékeket mutat. Középponti redoxpotenciálja $243 \pm 4 \mathrm{mV}$, ez valamivel alacsonyabb a natív fehérje redoxpotenciál értékénél $(260 \pm 5 \mathrm{mV})$. Aktivitás-méréseket végeztünk COX- 
szal, a citokróm $c$ fiziológiás elektronakceptor partnerével. Az aktivitást leíró paraméterek esetében a Michaelis-Menten konstans $\left(\mathrm{K}_{\mathrm{m}}\right)$, ami a COX-szal való komplexképzési képességét fejezi ki a citokróm $c$-nek, magasabb értéket mutat (ez a komplexképződés hatékonyságának a csökkenését jelenti). A másik paraméter, a $\mathrm{V}_{\max }$, amely végtelen szubsztrátkoncentráció esetén a termékképződés kezdeti sebessége, gyakorlatilag hibahatáron belül megegyezik az autentikus és az enzimatikusan érő fehérje ezen értékével. Indirekt módon további ismeretet szerezhettünk a nem-enzimatikusan érő citokróm $c$ szerkezeti és funkcionális integritásáról autoxidációs kísérletből is. Összehasonlítottuk párhuzamos kísérletben a redukált nem-enzimatikus fehérje hemjének automatikus oxidálódását az autentikus és az enzimatikusan érő változatok autoxidációjával. A nemenzimatikusan érő citokróm $c$ autoxidációjának sebessége ugyanolyan, mint az autentikus vagy az enzimatikusan érő citokrómé. A nem-enzmatikusan érő citokróm $c$ spektrumából a 695 nm-es csúcs, amelynek megléte a natív fehérje oxidált vasának 80-as metionin általi koordinációját jelenti, teljesen hiányzik.

A fenti ismeretekből az a következtetés vonható le, hogy a nem-enzimatikusan érő citokróm $c$ hemje két tioéter kötésen keresztül kötött ugyan, de a natív fehérjéhez viszonyított spektrális változásai és egyes fizikai-kémiai paramétereinek az eltérése a hem környezetének és/vagy geometriájának a minimális különbségeit tükrözik az autentikus fehérjéhez képest. Megállapíthatjuk tehát, hogy a CCHL szerepe a citokróm $c$ érlelésében egyrészt a hem és a ciszteinek közötti kovalens kötések létrejöttének katalizálása (tehát a folyamat hatékonyságának, sebességének növelése), másrészt a kialakult holocitokróm végső szerkezetének kialakítása, ami hatással van a hem közvetlen környezetére is.

A heterológ körülmények között müködöképes, élesztőből származó mitokondriális érlelő enzimet is kitisztítottuk szerkezetvizsgálati és in vitro érési kísérletek céljából. Tisztaságát denaturáló gélen megfuttatott mintán demonstráltuk, és a hozamát meghatároztuk ( 0,25 mg/g nedves sejt). Megfigyeltük, hogy denaturáló körülmények között a fehérje következetesen magasabbra szaladt, mint amire a molekulasúlya alapján számítani lehetett. Ebből a tényből (is) kiindulva egy IUPred nevü programmal predikciót végeztünk a fehérje szerkezetére vonatkozóan. Ez a program nagy biztonsággal azonosít rendezetlen szakaszokat fehérjékben. A program predikciója szerint a fehérjének az Nterminális végén egy kb. 67 aminosavnyi összefüggő szakasza rendezetlen szerkezetü, amelynek összetételében néhány rendezetlenséget elősegítő aminosav az átlaghoz képest többségben van. A másodlagos szerkezeti elemek vizsgálata céljából megmértük a fehérje UV cirkuláris dikroizmus (CD) spektrumát, és az így kapott spektrum illesztése alapján a 
fehérje 35,7 \%-a nem rendeződik másodlagos szerkezeti elemekbe. A szerkezetpredikció és a CD mérés eredménye, amelyekből a fehérje másodlagos szerkezeti elemeinek arányára tudunk következtetni, összhangban áll egymással.

A tisztított CCHL-lel hemmel való kölcsönhatási kísérleteket végeztünk in vitro. A hem és CCHL kölcsönhatását kétfázisú spektrális változás jellemzi. Az első fázis spektrális változását a szabad hem fogyásának tulajdonítjuk, miközben a hem és a CCHL interakcióba lépnek egymással. A második fázis során, amikor is kialakul egy hatszorosan koordinált, alacsony spinü hemre jellemző spektrum, a hem valószínüleg a hemszabályozó motívumok ciszteinjeivel lép kölcsönhatásba. Ezek alapján modellt fogalmazhatunk meg a hem és a CCHL kölcsönhatására. Eszerint a CCHL hemszabályozó motívumokat is tartalmazó rendezetlen szakasza a hemmel való kölcsönhatása során mintegy „becsomagolja” a hemet, kihasználva a rendezetlenségből eredő flexibilitást.

A tisztított CCHL-lel in vitro citokróm $c$ érési kísérleteket is végeztünk. Megállapítottuk, hogy erősen redukáló körülmények között az általunk termelt és tisztított CCHL képes in vitro citokrómot érlelni. Ezt a tényt a denaturáló körülmények között, gélen szétválasztott holocitokróm $c$ hem peroxidáz-aktivitásával és a reakcióelegy abszorpciós spektrum-változásaival bizonyítottuk. Eredményeink megnyitják az utat a CCHL szerkezetének és funkciójának, a hemmel és az apocitokrómmal való kölcsönhatásának megismerése felé. Munkánk során elértük azt a pontot, amikor a CCHL helyspecifikus mutációival a jövőben a mitokondriális citokróm $c$-nek, ennek a rendkívül fontos fehérjének az érési mechanizmusa feltárható lesz. 


\section{Summary}

$C$-type cytochromes are heme-containing proteins which bind their heme prosthetic group(s) covalently through thioether linkages. This link is usually established between the two vinyl groups of the heme and the heme binding motif (Cys-Xxx-Xxx-Cys-His) of the polypeptide chain. The histidine of the motif is the $5^{\text {th }}$ axial ligand of the heme. Xxx in the motif can designate any amino acid except cysteine. There is also a $6^{\text {th }}$ axial ligand of the heme iron in the $c$-type cytochromes, which is a distal methionine or histidine amino acid side chain of the polypeptide. There exist also cases which do not obey the above rules either in terms of the composition of the heme binding motif or the number of thioether links, and there are also variations in the $5^{\text {th }}$ axial ligand. There are cases where the heme is bound through a single vinyl group to a cysteine of a modified binding motif. And, finally, variations with more than two amino acids separating the two cysteines have also been reported.

The posttranslational modification of $c$-type cytochromes is referred to as maturation, which is assisted under natural conditions by a maturation system. Maturation systems of different complexity are known in various organisms, which can generally be sorted in three major groups. There are also exceptions, which are mainly specialized to recognize the above mentioned variants of the heme binding motif.

$C$-type cytochromes usually function as electron transporters in various redox processes, but they can also act as catalytic centers of enzymes. As a good example for multiple functions, the mitochondrial soluble cytochrome $c$ has an essential cascadeinducing role in apoptosis, in addition to its fundamental role in the respiratory electron transfer. We have used this mitochondrial cytochrome $c$ in our experiments. This protein carries electrons between its membrane-bound, proton-pumping enzyme partners in the intermembrane space, attached to the outer surface of the inner mitochondrial membrane. Covalent binding of the heme to the mitochondrial cytochrome $c$ is assisted by the simplest of the maturation systems. This comprises a single enzyme, the cytochrome $c$ heme lyase (CCHL), also known as holocytochrome $c$ synthetase, which is a soluble protein in strong interaction with the inner membrane. In some organisms (e.g. fungi) there exist two variants of CCHL, one for the maturation of cytochrome $c$ and another one for cytochrome $c_{1}$, but in higher organisms, including humans, a single enzyme is responsible for the maturation of both cytochromes.

We have used both wild type and site-directed mutant mitochondrial cytochromes $c$ 
in our electron transfer experiments, and the wild type in the postranslational maturation experiments. This small molecular weight mitochondrial redox protein is especially suitable for electron transfer experiments because (i) it is soluble and structurally stable (ii) its wild type and cysteine mutant variants can be expressed heterologously with high yield and (iii) its sequence contains no other cysteine but the two involved in the covalent heme binding.

For the electron transfer experiments we carefully designed and produced by PCR mutagenesis site directed cysteine mutants of cytochrome $c$ and labelled the overexpressed and purified proteins by an appropriate photoactive redox dye. We could vary the position of the electron donor dye by mutating various surface amino acids, which enabled the variation of the distance between the electron donor and acceptor (the heme). In additon, the composition of the protein matrix between donor and acceptor is also different depending on the label position. Another variant of the redox label can bind to lysine residues. By labelling the wild type protein as well, we could directly compare the electron transfer efficiency in case of two mutants (K8C and K39C). The covalent distance between the dye and the protein is one bond longer in case of the cysteine label. This difference should have resulted in a faster electron transfer in case of the lysine-labeled protein, if the electron followed the covalent pathway. According to our experimental results, the electron transfer kinetics measured with various label positions could only be fitted as sums of multiple exponentials, and there is no strong correlation relating the covalent distance between the donor and acceptor to the measured electron transfer rate. Our experimental results are supported by model calculations, where the dye, which is attached to the protein by a flexible covalent linker, can occupy multiple positions on the protein surface which are stable on the time scale of the electron transfer. In this way the ring moiety of the dye can assume positions so that the optimal electron transfer towards the heme does not necessarily take place along the covalent pathway, but starts instead by a through-space jump to a surface atom of the protein.

In order to produce mutants we have developed our own expression system. The principles of the system had been laid down by others, but we have constructed a reliable overexpression system which guarantees high yields, and have also solved the problem of easy replacement of the mutant genes. It is characterized by the co-expression of the maturation enzyme with the cytochrome $c$ in an E. coli strain (BL21-AI) ideal for protein overexpression, from a strictly regulated promoter (the arabinose-inducible $\mathrm{P}_{\mathrm{BAD}}$ promoter of the pBAD24 plasmid). Maturation takes place in the cytoplasm of the bacterium, with a yield as high as $\sim 5 \mathrm{mg} / 1 \mathrm{~g}$ wet cell mass in case of the wild type, which was determined from 
the spectrum of the supernatant after the first centrifugation purification step. The high yield enables its determination from the soluble fraction of the cell since the spectrum of the latter is dominated by the expressed cytochrome $c$. Similarly high yield of heterologous expression and maturation of cytochrome $c$ was achieved with another system, where the genes of cytochrome $c$ and CCHL were expressed from the promoters of two separate plasmids in non-stoichiometric ratios. We have co-transformed with the pBAD24 plasmid, carrying the gene of cytochrome $c$, another, genetically compatible plasmid from where the CCHL expression was induced by IPTG.

The heterologous expression of apocytochrome $c$ in the cytoplasm of $E$. coli has resulted in holocytochrome production even in the absence of the maturation enzyme, although at a much lower ( $2 \%$ of the enzymatic) yield. The non-enzymatically matured cytochrome $c$ is a functional protein, although with a slightly different absorption spectrum (its Soret peak shows a $2 \mathrm{~nm}$, and its $\alpha$ peak a $1 \mathrm{~nm}$ red-shift) and physicochemical parameters relative to the authentic and the enzymatically matured variants. We can ascribe the non-enzymatic maturation to the reducing conditions present in the bacterial cytoplasm and to the relative stability of the apocytochrome $c$. Without the enzymatic assistance, under these conditions the polypeptide chain and the heme may interact in such a way that, due to the proximity of the groups involved in the covalent binding, the thioether link can establish spontaneously (although much less efficiently than in the presence of the enzyme).

We have demonstrated the covalent heme-binding of the non-enzymatically matured cytochrome $c$ with denaturing polyacrylamide gel electrophoresis. We have detected chemiluminescence on the protein band separated under these conditions, originating from the peroxidase activity of the covalently bound heme. We have determined several physicochemical and spectral parameters of the non-enzymatically matured and purified cytochrome $c$. The pyridine hemochrome spectrum of the reduced protein has provided information about the covalent modification of the heme moiety, and hence about its proper binding to the polypeptide. Characteristically different maxima of the $\alpha$ band are observed in case of the unbound, the single thioether-bound and the double thioether-bound hemes. The pyridine hemochrome spectrum in case of the non-enzymatically matured cytochrome has demonstrated a double heme binding. The non-enzymatically matured cytochrome $c$ is functionally active and its activity parameters are close to those of the authentic and the enzymatically matured protein. Its midpoint redox potential relative to the standard hydrogene electrode is $243 \pm 4 \mathrm{mV}$, which is slightly lower than that of the native cytochrome $(260 \pm 5 \mathrm{mV})$. We have performed activity measurements with COX, the 
physiological electron acceptor partner of cytochrome $c$. Of the parameters describing the activity, the Michaelis-Menten constant $\left(\mathrm{K}_{\mathrm{m}}\right)$ which is characteristic of the complex forming affinity of the two proteins showed a somewhat higher value, which indicates a decrease of this complex forming affinity. The other parameter, $\mathrm{V}_{\max }$, which is the initial rate of product formation at infinite substrate concentration agrees practically, within error, with the value obtained with the authentic and the enzymatically matured cytochrome. We could obtain further indirect evidence about the structural and functional integrity of the nonenzymatically matured cytochrome $c$ from autoxidation experiments. In parallel experiments we have compared the rate of autoxidation of the heme of the nonenzymatically matured, reduced cytochrome $c$ with that of the enzymatically matured and the authentic proteins and observed no difference. However, the $695 \mathrm{~nm}$ absorption band, which is characteristic of the coordination of the oxidized iron in the native protein by methionine 80 , was missing from the spectrum of the oxidized non-enzymatically matured cytochrome $c$.

From the above pieces of information we could conclude that although the heme of the non-enzymatically matured cytochrome $c$ is bound naturally through two thioether bonds to the protein, minor spectral and physicochemical differences relative to the native cytochrome $c$ reflect small alterations in the environment and/or geometry of the heme. Thus the role of CCHL in the maturation of cytochrome $c$ involves on the one hand the catalysis (i.e. increase of the efficiency/rate) of the covalent attachment of the heme to the two cysteines and, on the other hand, the assistance in the formation of the final structure of the holocytochrome $c$, which affects directly the immediate environment of the heme.

We have also purified the mitochondrial maturation enzyme from yeast, which is catalytically active in the heterologous environment, for structural investigations and in vitro maturation studies. We have tested its purity by denaturing gel electrophoresis, and we have determined its yield $(\sim 0.25 \mathrm{mg} / \mathrm{g}$ wet cell mass). We have noticed that under denaturing conditions the protein band runs consistently at a higher molecular mass than expected from the sequence of CCHL. Based on this (and other) facts we have predicted the structure of the protein by the program IUPred. This program can identify with high fidelity disordered regions in a protein. According to the prediction a contiguous segment on the $\mathrm{N}$ terminal end, representing $\sim 25 \%$ of the total sequence is disordered, and contains an excess of some of the amino acids which typically promote disorder. In order to further characterize the secondary structure we have measured the UV circular dishroism (CD) spectrum of CCHL and fitted it with the program CDTOOL. This analysis yielded a total of 
$35.7 \%$ contribution by segments not assuming ordered secondary structure. The results of the prediction and the $\mathrm{CD}$ experiment are in good agreements in terms of the existence of a sizeable disordered region in the protein.

We have carried out in vitro experiments with the purified CCHL and its heme substrate to study their interaction. Their incubation yielded biphasic spectral changes over time. We attribute the first phase to the disappearance of free heme, while the heme and the protein establish interaction. During the second phase, when an absorption spectrum typical of 6-coordinated low spin heme develops, the heme is likely to become coordinated by the cysteines of the heme regulating motifs of CCHL. Based on these results we can propose a model for the interaction of CCHL with heme. According to our model the disordered segment of CCHL, which includes also the heme regulating motifs, is able to wrap the heme due to its disorder-related flexibility.

We have also performed in vitro maturation experiments with the purified CCHL and its heme and apocytochrome substrates. We have demonstrated that under strongly reducing conditions our heterologously produced and purified heme lyase is able to mature cytochrome $c$ in vitro. This was proven by the heme peroxidase activity of the holocytochrome band in denaturing gel as well as by the absorption spectrum of the reaction mixture. Our results open the way towards the better understanding of the structure and function of CCHL and its interaction with its two substrates, heme and apocytochrome. We have reached the point where by producing site specific mutants of CCHL in the future we will be able to explore the mechanism of the maturation of the exceptionally important protein, mitochondrial cytochrome $c$. 